

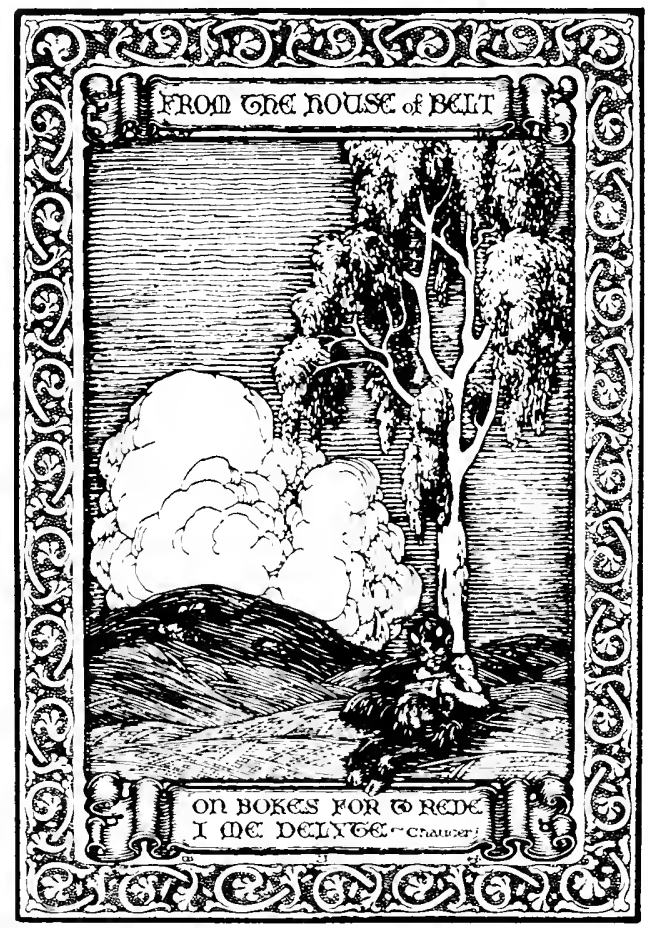




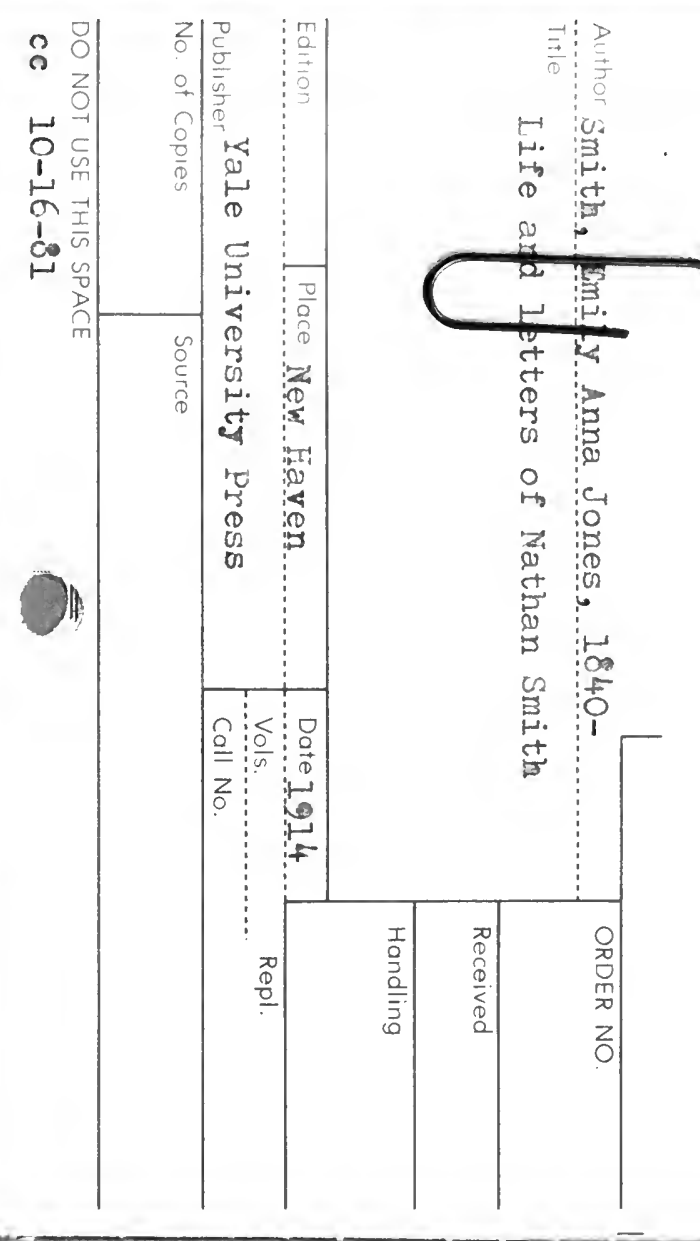


LIFE AND LETTERS OF NATHAN SMITH 




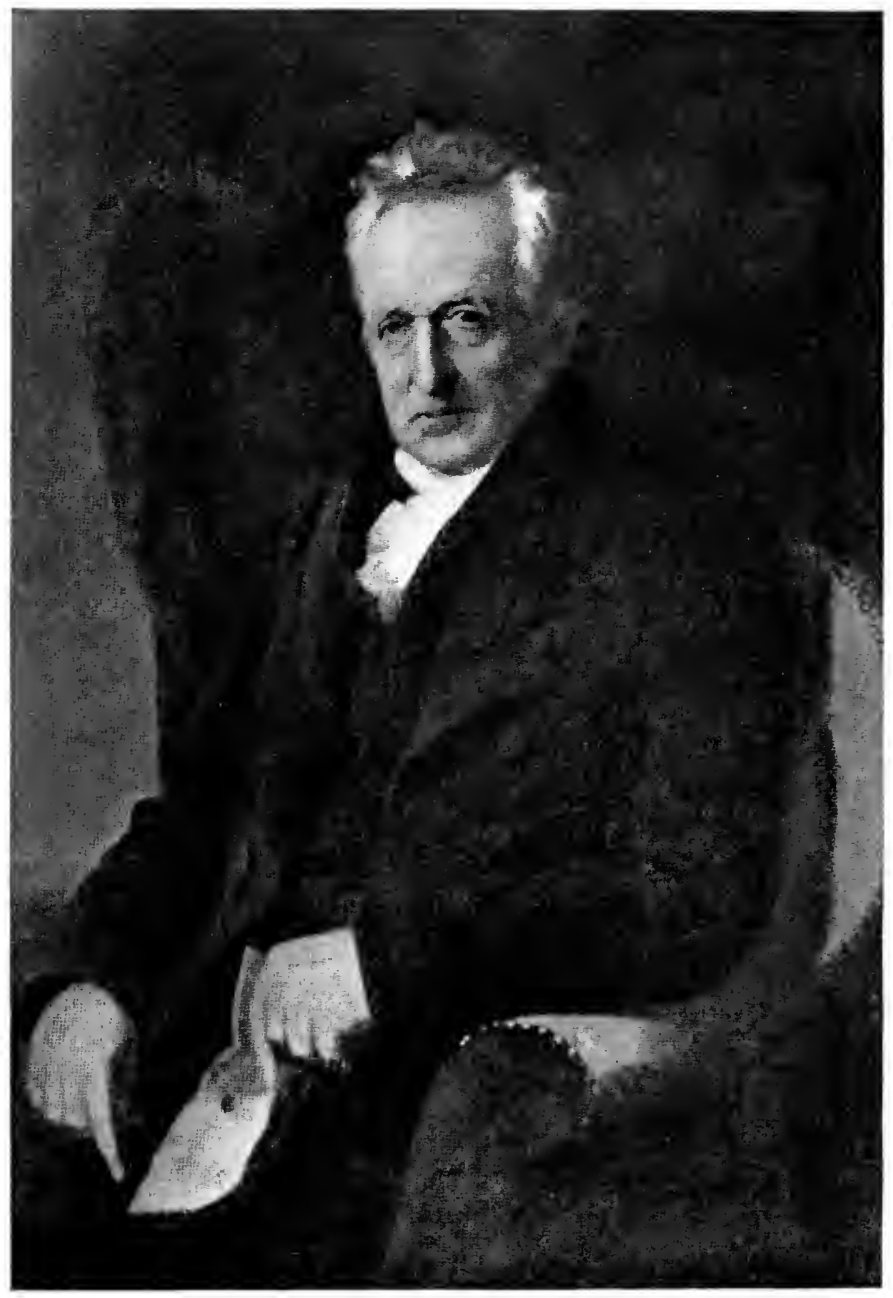

NAthan Silth, M. D.

Professor on Yale Medical Faculty, 1813-1829-From a portrait by - . 1. 13. Morse Presented to the Nedical School by the Class of 1826 


\title{
THE LIFE AND LETTERS OF
} NATHAN SMITH, M.B., M.D.

\author{
By \\ EMILY A. SMITH \\ With an Introduction BY \\ WILLIAM H. WELCH, M.D., LL.D.
}

New Haven: Yale University Press

London: Humphrey Milford

Oxford University Press

MDCCCCXIV 
COPYRIGHT, 1914

BY

Yale University Press

Pirst printed May. 1914, 1000 copies 


\section{$R$ \\ 154 \\ 563562 \\ 1914}

With deep gratitude and heart interest I dedicate this book to the members of the medical profession, who, following the leadership of those who have gone before, but with new light and better facilities, are laboring to relieve the pain and suffering of their fellow beings. 



\section{INTRODUCTION}

\section{By William H. Welch, M.D., LL.D.}

The medical profession and all interested in the history of medicine in this country owe a large debt to Mrs. Alan P. Smith for the preparation of "The Life and Letters of Nathan Smith," one of the most interesting and important figures in the history of American medicine. It is eminently fitting that this work should issue from the Yale University Press as a contribution to the celebration of the centennial anniversary of the opening of "The Medical Institution of Yale College," of which Dr. Smith was an organizer and chief ornament.

The main sources hitherto available for what is known of the life of Nathan Smith have been the addresses of Dr. Jonathan Knight and of the Rev. Dr. William Allen, delivered and published shortly after his death in 1829, the "Medical and Surgical Memoirs" by his son, Dr. Nathan R. Smith, published in I $83 \mathrm{I}$, and especially the "Historical Discourse" by Dr. Oliver P. Hubbard, printed in I 880 , to all of which repeated reference is made in this book. The many scattered estimates and accounts, mostly of an incidental nature, of the life and work of this remarkable man in medical writings have been drawn in the main from the foregoing sources. 


\section{Introduction}

To this rather meagre fund of information a substantial addition has been made by the painstaking and devoted investigations and labors of Mrs. Smith. Especially interesting are Dr. Smith's hitherto unpublished letters, particularly those, covering a period of nearly a quarter of a century, to his friend and pupil, Dr. George Cheyne Shattuck, an eminent physician of Boston and a benefactor of Dartmouth College and other educational institutions, and the extracts from Dr. Smith's ledgers and lecture notes.

Mrs. Smith has drawn a much clearer and fuller picture than had been done before of the setting of Nathan Smith's life, of his struggles and trials, of his indomitable courage and resourcefulness, of his marvelous capacity for work, of his professional and educational ideals and activities, and of his triumphs. We catch intimate glimpses of the active-minded lad upon the frontier, of the student at home and abroad getting, in spite of great difficulties, a good medical training, of the lover "transported with joy and expectation," of the devoted husband and father, solicitous for the education of his sons, of the busy physician and surgeon, "bandied about from one part of the country to the other," treating fevers, couching for cataract, cutting for stone, excising tumors, and embarrassed most of the time, as is the way of doctors, from failure or inability to collect his fees, small as they were, of the founder of medical schools and the professor, filling and filling well all the chairs in the medical curriculum,-from all accounts a really great teacher, and withal deserving President Woolsey's characterization of him as "the 


\section{Introduction}

most delightful, unselfish and kind-hearted man I ever knew, and we children all loved him."

Dr. Smith's letters to Shattuck remind one not a little of John Hunter's correspondence with his former pupil, Jenner. How suggestive of Hunter's many commissions imposed upon Jenner is the letter (on page 47 of this book) beginning, "I am continually troubling you about many things!" . . . "If you have a man in Boston who makes thermometers, and if he can do it, I wish also to have an air thermometer constructed according to Henry's directions in his chapter on Caloric. I presume you can find that book in Boston, and the workman may follow that in his work." The repeated requests to send chemicals, apparatus, instruments and books afford some insight into Dr. Smith's scientific interests and activities, as does also the novel task assigned to two of his pupils to read through fifty-two volumes of historical works, recently added to his library, in order to cull out and index "everything relating to medicine or medical men."

The difference between the mental attitudes toward medical science of Nathan Smith and of his older contemporary, Benjamin Rush, is made clear in the letter to Dr. Shattuck when a student in Philadelphia. Rush, the greatest historical figure in American medicine, belonged essentially to the group of systematists of the eighteenth century. Dr. Smith writes: "Dr. Rush must be a very interesting lecturer. As to his classification of diseases I do not think it very material. However we may class diseases, we must study them in detail. . . . As to the unity of disease, you know it is my opinion 
that we have in medical science of late generalized too much and that the progress of medicine has been checked by it. This mode of proceeding tends to substitute idleness for industry, and dogmatism for patient inquiry."

None of Nathan Smith's contemporaries in this country was possessed in larger measure of the true spirit and method of scientific inquiry. A very remarkable vision of the benefits that must accrue to medicine by the applications of chemistry and of the experimental method to the problems of disease is presented in the extract from one of his lectures on chemistry printed on page 79 of this book.

Nathan Smith was one of the earliest and best of the new generation of medical men who came to the front in the quarter of a century immediately following the War of the Revolution and gave to American medicine a self-reliance, an adaptation to the needs of a rapidly expanding country, an activity and a productivity previously unknown. Only two medical schools, one in Philadelphia and one in New York, had been established in the decade preceding the Revolution; now new medical schools, societies and journals were founded and the practice of medicine and of surgery was brought fully abreast of the times. While the most familiar names of this heroic period are of physicians and surgeons of the cities on or near the Atlantic seaboard, as John Warren, Samuel Bard, Wright Post, David Hosack, Benjamin Rush, Philip Syng Physick, David Ramsay, yet in many ways the most original, interesting and distinctively American are those of the frontier, as 


\section{Introduction}

Ephraim McDowell, Benjamin W. Dudley and Daniel Drake. Dr. Nathan Smith had closer kinship with this latter group than with the former. In his early years the parts of Vermont and New Hampshire where he lived were scarcely less frontier settlements than were Kentucky and Ohio. Smith, like McDowell and Dudley, received an excellent medical training, enjoying the advantages of European study, but not the least valuable part of the training of these men was acquired during their youth in the woods and the fields under the primitive conditions of pioneer life, imparting that vigor, virility, keenness of observation, resourcefulness and fund of good sense which characterized them.

In his day Nathan Smith shared with John Warren a position of unexampled preëminence in the medical profession of New England, his activities extending over a wider territory and including all of that region except eastern Massachusetts and Rhode Island. $\mathrm{He}$ is a remarkable example of equal eminence in internal medicine and in surgery. Only a later generation could appreciate fully how original and great was the contribution to medicine which he made in his essay on "Typhus Fever," now a medical classic. Probably the first adequate appreciation by a competent authority of Dr. Smith's "Observations on the Pathology and Treatment of Necrosis" is that of the distinguished surgeon, Frederick Lange, in his paper on osteomyelitis in the "Festschrift" in honor of von Esmarch, published in 1893. Both of these famous essays are models of keen observation, accurate description, correct inference, ex- 
pressed in clear and simple language and presenting admirable pictures of the conditions described.

Mrs. Smith has set forth fully the interesting circumstances of Nathan Smith's unprecedented activities connected with the establishment of four medical schools, those of Dartmouth, Yale, Bowdoin and the University of Vermont. The only one of these schools which he actually initiated was that of Dartmouth, where for twelve years he taught, with only occasional and slight assistance, all of the subjects then included in the medical curriculum, and we know that he taught them well. Few teachers have ever been held in greater esteem and affection by pupils than was Dr. Smith. One cannot restrain a feeling of regret, although sympathizing with the enlightened decision necessitated by the changed conditions of medical education, that the Dartmouth Medical School, with its long and honorable history, is to discontinue the last two years of the course after the present session.

That Dr. Smith did not believe in the unnecessary multiplication of medical schools is apparent from a statement in his letter to Dr. Shattuck of April I8, I 823 (on page I 22): "I think the four schools which I have been concerned in bringing forward, in addition to Harvard, will be as much as New England will bear, and I think there will not be too many. Every state should have one medical school and no more." It would have been well for medical education in this country if this standard had been maintained, and well too if his example had been followed of establishing 


\section{Introduction}

such schools only in association with colleges or universities.

Coming to New Haven in 18 I 3 in the fullness of his powers, Nathan Smith was by far the most distinguished member of the first faculty of the Yale Medical School and the one most active in its organization and development. Here, too, was the scene of his most productive activities, of his widest influence and greatest usefulness. If provided with adequate resources, the Yale Medical School, favorably located in connection with a great university, is in a position to enter upon the second century of its existence with a well-founded expectation of renown and usefulness surpassing even the high hopes of Nathan Smith, under whom it had attained a large measure of prosperity.

It is related that the first President Dwight was accustomed to give a brief sketch of the events of Nathan Smith's life to the senior class of Yale College "in order to awaken their ambition and to encourage them in surmounting difficulties." It was indeed a life full of useful lessons, and many will be grateful to Mrs. Smith for this memorial volume, which will help to extend and perpetuate the fame of a great physician, teacher and builder, whose name stands high in the medical annals of this country. Several of the descendants of Nathan Smith became distinguished in medicine and an interest attaches to the short biographical notices of other members of this remarkable family of physicians. 



\section{FOREWORD}

It gives me great pleasure to fulfil what I consider a sacred trust, by contributing to the Medical School of Yale University a brief sketch of the remarkable life of Dr. Nathan Smith, with many of his heretofore unpublished letters and extracts from his ledgers kept at Dartmouth and Yale.

No attempt has been made in this compilation to dilate upon the history or to do more than connect the letters with the various incidents of the life of Dr. Smith by arranging them in chronological order.

Since I have been the guardian of his valuable papers, a steady growth of interest has been manifested in them and in their author, who is now recognized by the medical profession to have been in medicine one of the greatest men of his day in America, a pioneer, who made important innovations in the treatment of diseases, raising the standard of medical science from a very low estate-and who in the face of almost insurmountable difficulties founded medical schools where he taught hundreds and perhaps thousands of men, of whom many have become shining lights in the medical profession.

This biography will show that Dr. Nathan Smith was practically the founder of the Yale Medical School in the year 1813 , for he not only supplied the first lectureships in the Theory and Practice of Physic, of Surgery and of Obstetrics, but, by his own personal 
application to the Legislature of Connecticut, obtained a grant of twenty thousand dollars to start the medical buildings.

It will also be shown that it was during Dr. Smith's sojourn at $\mathrm{New}$ Haven that he accomplished his best work in teaching, writing, and attending the sick.

In consideration of Dr. Nathan Smith's important connection with the Medical School of Yale University, there would appear to be no better way of celebrating the Centennial Anniversary of its opening than in honoring its distinguished founder by putting into some permanent form an account of his remarkable life and a collection of his writings as a fitting memorial to his beloved memory.

In the summer of I9Io it was my privilege to visit the early home of Dr. Nathan Smith at Cornish, N. H., and some of the colleges connected with his work.

At Dartmouth, Prof. John K. Lord loaned me some interesting letters written by Dr. Smith, and Dr. Gilman D. Frost showed great kindness in taking me through the old medical building for which Dr. Smith gave the land, and in which in 1798 he started the first medical school in New Hampshire by filling all the chairs himself.

At Yale, Dr. Wm. H. Carmalt took pains to help on my work and by his continued kindness has done much to further its completion.

I feel that I owe thanks to many who have aided me in one way or another. Mrs. Nathan Smith Lincoln and other ladies of the family have contributed letters and photographs, and Drs. Frederick C. Shattuck, 
William H. Welch, Samuel C. Chew, of the University of Maryland, James A. Spalding, Alfred Mitchell, of Bowdoin College, and Samuel Theobald, of Johns Hopkins University, have all aided by supplying letters or giving permission to quote from their writings. To no two friends do I feel more gratitude than to the late Dr. John Taylor Gilman Nichols, who encouraged me to compile the biography, and to Dr. Henry M. Hurd, without whose substantial interest the work might have received no further recognition.

I have also been aided by Dr. Nathan Ryno Smith and Dr. Eugene McEvers Van Ness, who gave much time and the benefit of their medical knowledge to examining the manuscripts of Dr. Nathan Smith and to deciphering his very difficult handwriting. For some of the early accounts of Cornish I am indebted to Mrs. Laura Chase Smith and her very interesting history of her grandfather, Bishop Philander Chase. Mr. Carroll Smith, of Albany, kindly contributed items from the genealogy of the family.

I am deeply grateful to Mrs. Robert Nelson Corwin for her very careful editorial work and also for the addition of many of the footnotes and a few historical items of much interest.

Emily A. Sмiтн.

August I8, 1913. 



\section{TABLE OF CONTENTS}

Chapter

I. The Landing of the "Diligent" in 1638 . . 1

II. Exciting adventures of Nathan Smith's early days. War with Indians. $\mathrm{He}$ becomes a teacher. Assists at a surgical operation and decides to study medicine

III. His removal to Cornish, New Hampshire, to practice medicine. The Chases and Spaldings his friends there. Goes to Harvard and takes degree of M.B. in 1790. Marriage with Elizabeth, daughter of General Chase. Death of wife and marriage, the following year, with her half-sister, Sarah . . . .

IV. Nathan Smith offers to establish a medical department at Hanover. Sails on Bark "Hope" for Edinburgh to continue studies. Returns after nine months with books and instruments for his work. Honored by London Medical Society • • • • • •

V. Dr. Smith founds Dartmouth Medical School in 1797. Sole teacher in all branches. Degree of A.M. conferred upon him by Dartmouth in 1798. Rapid growth of the school under difficulties. Dr. Smith practices vaccination in 1800. Extracts from his ledger of 1800. Lists of pupils, including Daniel Webster. M.D. from Dartmouth, 1801 .

VI. Friendships with pupils. Letters to Dr. George C. Shattuck; one of the earliest, with comments on the teaching of his contemporary, Dr. Benjamin Rush, of Philadelphia. Dr. 
Chapter

Smith gets grant from Legislature of New Hampshire to build a home for the Medical School; he gives land and assigns his anatomical museum and chemical apparatus to the State

VII. Difficulties and trials followed by honors. Dr. Smith elected president of the State Medical Society. Renewed honor by London Medical Society. M.D. from Harvard, 1811. More letters to Dr. Shattuck. Famous prophecy in his lecture on Chemistry .

VIII. In letter to Dr. Shattuck of April 15, 1811, some account of his family is given, and a full description of the origin of the Dartmouth Medical School. Other important letters . . . . . . . . . . .

IX. Description of the old medical building. Great discouragements come to Dr. Smith at Dartmouth. In 1812 he is invited to assist the trustees of Yale College in establishing a medical department there, by becoming Professor of the Theory and Practice of Physic, Surgery and Obstetrics. Accepts proposition

X. Dr. Nathan Smith leaves Dartmouth for New Haven, taking with him his sons, David Solon and Nathan Ryno, to enter at Yale as pupils. Teaching and practice in New Haven

XI. Dr. Smith's manner of lecturing. Makes personal application to the Legislature of Connecticut for a grant of funds and receives twenty thousand dollars for the medical 
Chapter

buildings at Yale. Dr. Smith's affliction in loss of his eldest daughter. Moves family to New Haven . . . . . . . .

XII. David Solon receives degree of M.D. in 1816. Nathan Ryno, the second son, writes a play and performs in it. Receives degree of A.B. in 1817 and leaves to be tutor in a Virginia family. Solon goes west to study botany. More letters to Dr. Shattuck. Extracts from records in family Bible. Marriages of elder children

XIII. In 1820 the Legislature of Maine endows a medical school. Dr. Smith is consulted and placed at the head of it and thus assists in establishing the medical school in connection with Bowdoin College at Brunswick, Maine

XIV. Dr. Smith lectures at both Bowdoin and Yale. Extracts from his ledger kept at New Haven in 1821 and 1822, with list of students there. Dr. Solon Smith marries and settles at Sutton. Dr. Nathan Ryno Smith returns to Yale and receives degree of M.D. there in 1820. Begins practice at Burlington and marries there. $\mathrm{He}$ is called to the University of Vermont, where with his father he establishes a medical department in 1821 and becomes Professor of Surgery and Anatomy

$X V$. Letters to Dr. Shattuck from Dr. Nathan Smith from Brunswick and New Haven; the one of April 18,1823, mentions completion of his well-known treatise on typhoid fever. The work of Dr. Nathan Smith com- 
Chapter

mented upon by Professor Knight of New Haven . . . . . . . . . . 121

XVI. Dr. Nathan Ryno Smith goes to Philadelphia, where, as Professor of Anatomy, he joins Dr. George McClellan in founding the Jefferson Medical School, advised and assisted by Dr. Nathan Smith and Dr. George C. Shattuck. Letters from the elder Dr. Smith to Dr. Shattuck. Financial cares . . . . . . . 130

XVII. Dr. Nathan Ryno Smith is called to chair of Surgery in the University of Maryland, and leaves Philadelphia for Baltimore. Last letter of Dr. Nathan Smith to Dr. Shattuck, dated New Haven, December 8, 1827, speaks with pride and affection of his family. Letter from Dr. N. R. Smith upon hearing of the extreme illness of his father. . .

XVIII. The death of Nathan Smith, surrounded by his family and his beloved pupils. Dr. Shattuck soothes his last hours by promised care of the education of his youngest son. Professor Knight's eulogium . . . . . .

XIX. Resolutions passed containing eulogies and testimonials of honor to the memory of Nathan Smith during the course of the century almost elapsed since his death . . . . . . 147

XX. Medical men descended from Nathan Smith . 156

The Appendix:

Containing an account of the writings of Dr. Nathan Smith. His Introductory Lecture delivered at Yale in 1813 . . . . . . 


\section{LIST OF ILLUSTRATIONS}

Nathan Smith, M.D. . . . . . . Frontispiece

PAGE

One of the Jonathan Chase Houses at Cornish . . . 6

The Episcopal Church at Cornish . . . . . . . 10

The Graveyard Next to the Episcopal Church . . . 10

General Jonathan Chase . . . . . . . . . 12

Mrs. Jonathan Chase . . . . . . . . . . 14

One of the Homes of General Jonathan Chase at Cornish 20

The Connecticut River near Hanover, N. H. . . . . 22

The Book Plate of Dr. Nathan Smith . . . . . 26

Photograph of a Page from Dr. Smith's Ledger Kept at

Dartmouth, 1800-1801 . . . . . . . . 28

The Old Medical Building at Dartmouth . . . . 76

The Nathan Smith Laboratory at Dartmouth . . . 80

Photograph from the Ledger of Dr. Smith Kept at Yale,

1813-1814 . . . . . . . . . . . . 92

Yale College in 1807 . . . . . . . . . . 96

Photograph of Invitation for Junior Exhibition, Yale

College, 1816 . . . . . . . . . . . . 102

Yale Medical College in 1840 . . . . . . . . 108

Photograph of Original Ticket to Dr. Smith's Lectures

at Yale College, 1821 . . . . . . . . 116

Mrs. Frances (Montesque Buchanan Allen) Penniman . 118

Mrs. Margaret (Schoolcraft) Montesque Wall . . 120

Dr. Nathan Ryno Smith (from Miniature) . . . . 136

The Grave of Dr. Nathan Smith . . . . . . . 142

Dr. David Solon Chase Hall Smith . . . . . . 156

Dr. Nathan Ryno Smith . . . . . . . . . 158

Dr. James Morven Smith . . . . . . . . 160

Dr. John Derby Smith . . . . . . . . . 162 



\section{NATHAN SMITH}

Harvard- M.B. 1790. M.D. 1811.

Dartmouth-A.M. 1798. M.D. 1801.

Corresponding member of the Medical Society of London, 1797.

Founder of the Medical School of Dartmouth, 1798.

Dartmouth-Professor of Anatomy, Surgery, Chemistry, and Theory and Practice of Medicine, 1798 to 1810.

Dartmouth-Professor of Chemistry, and Theory and Practice of Medicine, 1810 to 1813.

Yale- $\quad$ First Professor of Theory and Practice of Physic, Surgery and Obstetrics, 1813 to 1829.

Bowdoin- With President Allen the inaugurator of the Medical School in connection with Bowdoin College, Maine, 1821 to 1826.

Bowdoin - Professor of Anatomy, Surgery, and Theory and Practice of Medicine, 1821 to 1823. Professor of Theory and Practice of Medicine, 1821 to 1826.

Burlington-Together with his son, Dr. Nathan Ryno Smith, founder of the Medical School of the University of Vermont at Burlington, 1820.

Born September 30, 1762-Died January 26, 1829. 

LIFE AND LETTERS OF NATHAN SMITH 



\section{CHAPTER FIRST}

\section{The Landing of the "Diligent" in 1638}

Within a few months of the ordering of a school or college at Newetowne, and in the memorable year when the name of Newetowne was changed, henceforward to be called Cambridge, no less than twenty ships plowed their way across the unusually stormy waters of the Atlantic, bringing to the shores of America at least three thousand persons, many of whom were men and women of quality and estate who were seeking freedom from religious persecution and who were to be the founders of the great Republic of the United States,-among them men wisely called "the greatest geniuses for government that the world ever saw embarked together in one common cause."

One of these twenty ships was the good "Diligent" of Ipswich, which, on August ro, 1638, safely landed her cargo of one hundred and thirty-three souls, brought from Old Hingham, England, to the New Hingham in New England. Some of these men were destined to become important factors in laying the firm foundation for prosperity and peace upon which future men were to build. There were the Gilmans, Lincolns, Cushings, Coopers, Folsoms and others.

Many of these families had been the parishioners of the Rev. Robert Peck, under whose leadership they had come to the land where religious toleration existed 
for all. Among the one hundred and thirty-three passengers of the "Diligent" was a Mr. Henry Smith, who, with his wife, Judith, their three sons and two daughters, three men servants and two maid servants, was from Hargham Hall, Norfolk County, England. English histories refer to this Henry Smith as one of the prominent men who emigrated to New England on account of religious controversies then existing.

Mr. Henry Smith's five children were all born and educated in England, and, as the term "Mr." indicates, he himself had been a college graduate, and in the new country became a useful citizen and was, in $164 \mathrm{I}$, a representative in General Court.

His son, Henry, Jr., called Ensign Henry, a man of superior culture and an engineer, surveyed the Rehoboth North Purchase, Attleboro, Mass., and Cumberland, R. I., with Mr. Carpenter; also the Douams Purchase, Barrington, R. I., and many other places; he, likewise, was a representative in General Court in I662.

Ensign Henry Smith's son, called Deacon Henry, married Rebecca Atwood and they were the parents of John Smith, whose second wife, Elizabeth (Ide) Hills, was the mother of Nathan Smith of this history.

The family of the first Henry Smith removed, not very long after their landing, from Hingham to Rehoboth, where it took root and flourished for four generations.

Here, on September 30, I 762, a son, Nathan, was born to John Smith and Elizabeth, his wife. They subsequently removed to Chester, Vt., but the exact 
time or cause for this step is not known. Accounts of the boyhood days of Nathan Smith indicate that his father was a pioneer among the farmers of that district. 


\section{CHAPTER SECOND}

The youthful days of Nathan Smith were spent upon his father's farm, aiding in the usual duties in garden and fields and in the care of the domestic animals; but there were times when he had experiences exciting enough to suit the most ambitious taste for adventure. His hunting and fishing excursions were in the wilds of the frontier lands, where it is said that on one occasion he was lost for three days in one of the dense forests where lofty pines sometimes reached to the height of 270 feet, and the thick undergrowth in places often concealed wild beasts as well as hostile and treacherous Indians. It may well be imagined that under such circumstances as then surrounded the young Nathan, he must have acquired very early in life great courage and self-reliance, especially as, beneath the natural love which boys usually have for sports, he possessed from the first uncommon force of character and a great ambition to acquire knowledge and use it for the benefit of others. It is recorded of him that at the close of the Revolutionary War, when still a youth, he served with the Vermont militia to protect the inhabitants against the incursions of the Indians, and at one time "narrowly escaped a bullet aimed at him by a son of the forest from his place of ambush." Evidently his military conduct gained approval, for at the age of eighteen years he was promoted from the ranks to a captaincy in his regiment. 
A little later we hear of him as a teacher in a district school, showing that, although a farmer's boy, his early education had not been neglected by his father, who was descended from cultured people.

While engaged in this work of teaching, his interest was aroused on hearing that Dr. Goodhue, a noted surgeon of the time, was coming from Putney, Vt., to amputate the leg of a man in Chester. Together with others, young Smith repaired to the spot to watch the operation and when Dr. Goodhue asked if any one present would assist him by holding the leg, Nathan Smith stepped boldly forward and with unflinching nerve gave his aid, even so far as to tie the arteries without a tremor. After the operation was completed and many had left the house, young Smith expressed to Dr. Goodhue his intense desire to study medicine, proposing to begin as soon as the school term should close. But after questioning him as to his acquirements, Dr. Goodhue wisely advised more preparation as a foundation for the all-important profession of medicine and surgery, and told the ambitious youth that he must be qualified to enter the Freshman class at Harvard before beginning medical studies.

After a year had passed, when probably the doctor had forgotten all about his aspiring young assistant at Chester, he was surprised one day by the arrival of Nathan Smith at his home, claiming his promise to act as his instructor. Dr. Goodhue found that this remarkable young man had fulfilled all of the conditions which he had made by studying industriously during the year with the Rev. Mr. Whiting of Rockingham, Vt., and, 
persuaded of rare characteristics in Nathan Smith, then just twenty-two years of age, Dr. Goodhue offered him a home and medical tuition in return for certain work necessary in the country home of a physician. Three years were thus passed, during which time a strong intimacy and lifelong friendship grew up between the instructor and his pupil.

In the year 1787 , when twenty-five years of age, Nathan Smith began the practice of medicine at Cornish, N. H., before he had received a degree from any of the three medical schools then existing in the United States, this plan of entering the medical profession being customary in that day. 


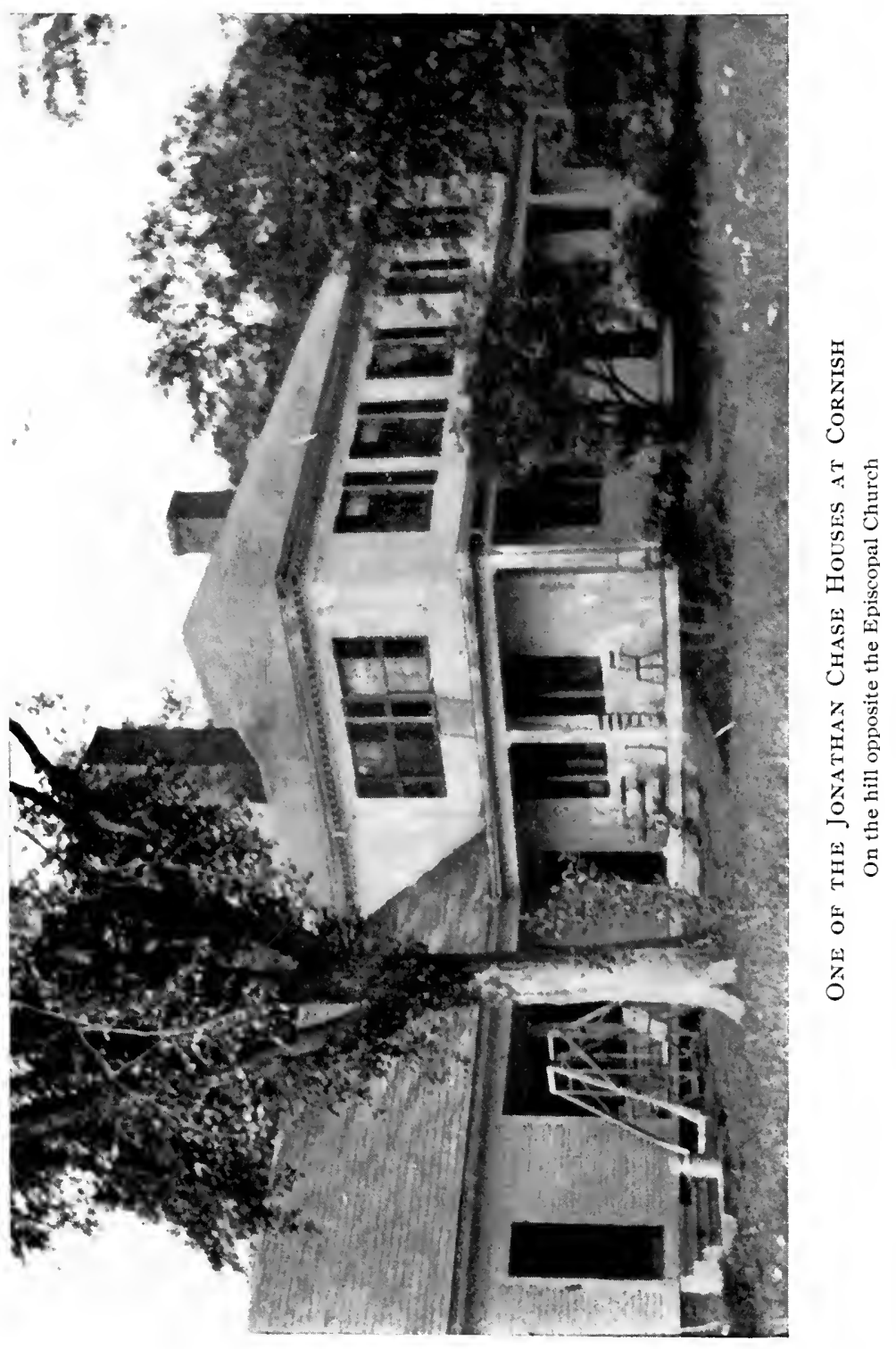





\section{CHAPTER THIRD}

Beautiful Cornish, N. H., Where Dr. Nathan Smith Began the Practice of Medicine

In order to understand the early life of Nathan Smith at Cornish, it is necessary to know something of the state of the country in that neighborhood when he began his work there.

Only about thirty years had elapsed since Dudley Chase and Dyer Spalding, with a party of workmen, had gone from Fort No. 4 (Charlestown), then the northernmost settlement in the State of New Hampshire, to a well-chosen spot sixteen miles up the Connecticut River, where they were to fell the great forest trees, clear the ground and start the little town of Cornish. A thrillingly interesting account of the undertaking is given in the beautiful history of Dudley Chase's son, Philander, who became the first Bishop of Ohio and Illinois. It is stated that the brave and lovely wife of Dudley Chase, Mistress Allace Corbett, was so anxious to share the companionship and perils of her husband in this enterprise that she prevailed upon $\mathrm{Mr}$. Dyer Spalding, who had returned to the fort for provisions, to take her and her seven little children in a canoe to join her husband before the men had found time even to build a log cabin for their shelter; but a tent of long strips of bark was soon made by the loving hands of the men for her and her little ones, and no doubt the heroic woman was able to add much to the comfort of 
these, the first settlers of Cornish. Dudley's brother Jonathan and their father, Judge Samuel Chase, of Aquilla's family of Newbury, soon followed him from Sutton, Mass., their native town, to Cornish, and the settlement became especially identified with the Chases and Spaldings.

The first thirty years of the existence of Cornish had brought many stirring events and changes not only to the settlers of the little town but to the whole country; for during that time freedom from England was obtained by the Revolutionary War. The inhabitants of Cornish had contributed their share in bringing this to pass; marching under the leadership of General Jonathan Chase were many neighbors, including Jonathan's venerable father, Samuel Chase, judge of the County of Cheshire, N. H., already seventy years of age. This regiment marched from Cornish to Bennington, Vt., and to Saratoga, N. Y., and was present at the surrender of General Burgoyne. But to the residents of the little town of Cornish, so far inland as to be removed even from the news of the great battles, Indians as enemies were even more to be dreaded than enemies from foreign lands, for at that time savages infested the neighboring forests and were constantly ready to attack.

In I780, just seven years before Nathan Smith came to Cornish, Royalton, Vt., only a few miles away, had been burned and destroyed and seven men of Randolph, its near neighbor, had been captured and kept prisoners by the Indians for two years. But in this heroic age, the courage and energy of the pioneers 
were boundless, - the men, like the builders of the walls of Jerusalem in Nehemiah's time, had their implements of defense always at hand while with a "mind to work" they cleared the land, built their homes, made their own farm implements and attended to their flocks and herds. The women, no less busy, carded wool, made cloth by the aid of the loom and the spinning wheel, knitted stockings and attended to the pickling and preserving of meats and fruits as well as to the cooking of the food. Not many idle moments could have been spent by these early settlers of the country and yet they seem to have had time for the education of their children. Four of the sons of Dudley Chase graduated from Dartmouth, while Allace, one of his daughters, is said to have been able to repeat the whole of Homer's Iliad and to have kept up with her brothers in their studies at Dartmouth.

But this period of the country's history was so marked in many districts by great ignorance and superstition in regard to the care of the sick, that the presence of a well-trained young physician among them received a kindly and hearty welcome from the families at Cornish, and a special intimacy grew up between the Chases and Spaldings and Nathan Smith. Young Lyman Spalding, then a lad of twelve or fifteen years, became his ardent admirer, and from that time was so influenced by his example and good work that he resolved to enter the medical profession, in which he afterwards rose to distinction.

We are not informed as to Dr. Smith's reason for selecting this Cornish region for his professional work, 
but, as artists and authors of this day have discovered, no one could visit the neighborhood without being impressed by its natural advantages and beauty.

Nestled at the very foot of Mt. Ascutney, on a broad bend of the Connecticut River, is the little town of Windsor, Vt., which, by means of a most picturesque old covered bridge, spanning the river, is so connected with Cornish that the two villages are practically one. From this bridge, through a wonderful New England forest, a short road leads up to the part of Cornish once owned by General Jonathan Chase and his family, and it is evidently here that Dr. Smith spent much of his time.

Two years of practice at Cornish but served to impress upon the young physician the importance of further knowledge in the great field of medicine and surgery. Accordingly he gave up his practice there to go to Cambridge, where he attended "the lectures of Dr. John Warren on Anatomy and Surgery, Dr. Aaron Dexter on Chemistry and Materia Medica, and Dr. Benjamin Waterhouse, of the Medical Department, on Theory and Practice of Medicine; besides the medical lectures he attended those of Professor Samuel Webber on Natural Philosophy, in the College; and these together probably constituted his first course of lectures. At the Harvard Commencement in I790, he took the degree of M.B. (Bachelor of Medicine), the only one in a class of four, and the fourth graduate in the Medical School of Harvard." It was on that occasion that he

\footnotetext{
1 The statement stands as quoted in Dr. Hubbard's discourse, and he evidently derived his facts from Dr. Oliver Wendell Holmes. The
} 


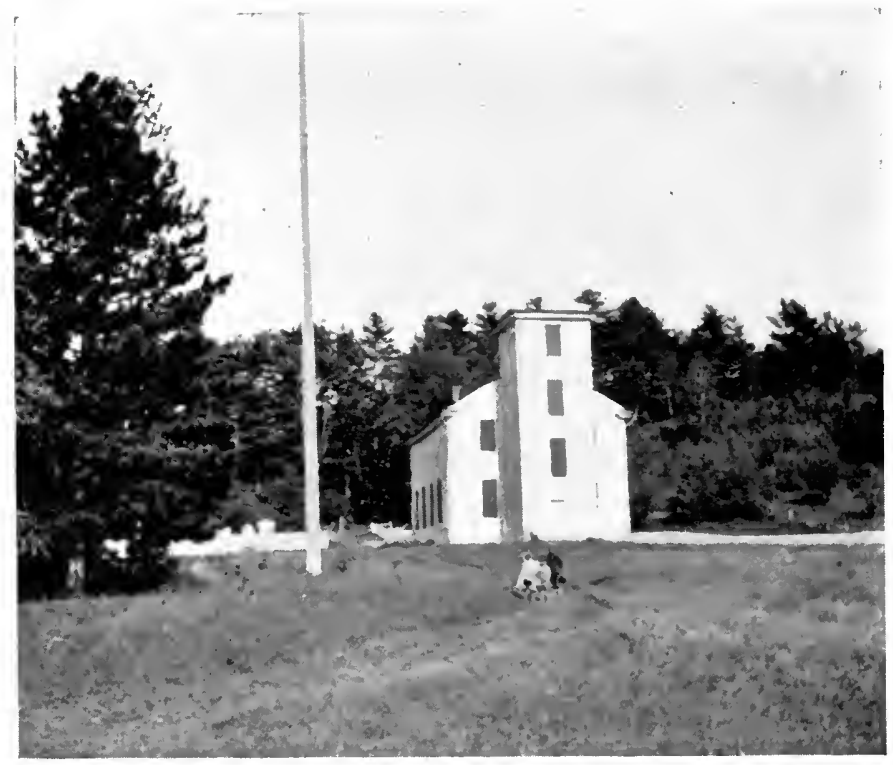

The Episcopal. Church at Cornish

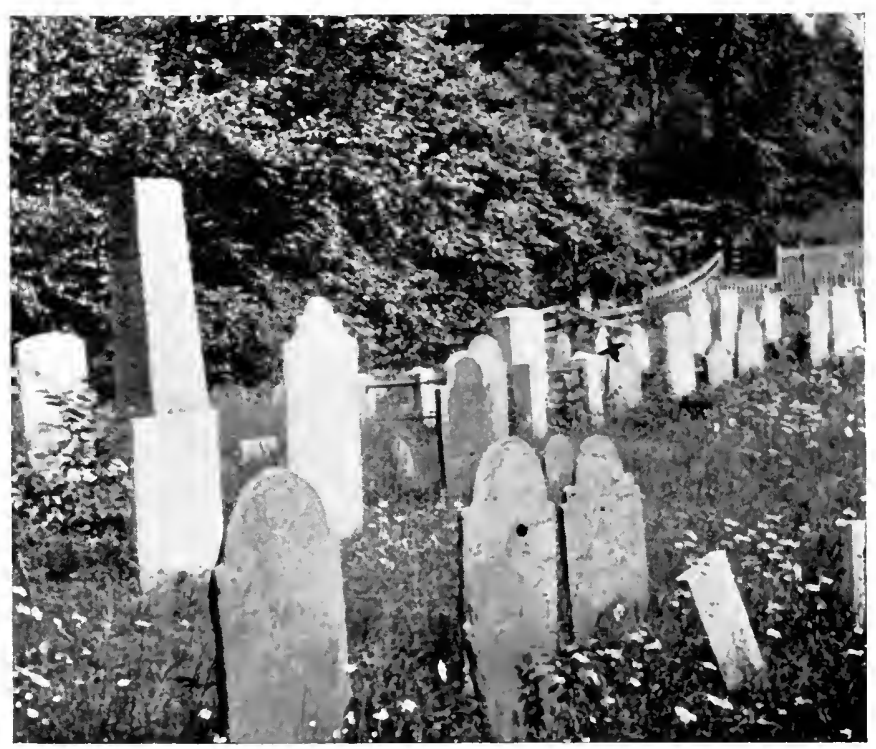

The Graveyard Next to the Episcopal Church

The grave marked is that of Elizabeth, the first wife of Dr. Nathan Smith 

read an "Inaugural Dissertation on the Circulation of the Blood," which was received with high approbation and published at the request of the faculty.

Immediately after the receipt of his diploma, Dr. Smith returned to his friends and professional work at Cornish, where his friendship with the Chases was cemented by his marriage on January I6, I79I, with Elizabeth, one of the daughters of General Jonathan and his first wife, Thankful Sherman Chase. But his happiness with his young wife was of short duration, for she died on April r4, r793, leaving no children. In those early days, however, it was universally felt that "it is not good that a man should be alone"; exigencies of home life demanded that each man should provide himself a helpmeet and early marriages were the order of the day. When death separated even the most loving couples, second and third marriages were often contracted.

Such being the custom it is not surprising to learn that some time after the death of Elizabeth, Dr. Smith began to realize a growing interest in the bright and gifted Sarah, a half-sister of his wife, and daughter of the General and his second wife, Sarah (Hall) Chase.

account in the Harvard Quinquennial Catalogue does not, however, bear out this statement, and application to the authorities at Harvard reveals the fact that, since the writing of the above, three names have been added to the list of graduates in medicine, making a showing of two names, instead of one, to each of the first three classes. "Since 1875, and especially at the time the Quinquennial Catalogue was translated from Latin to English, the Corporation records were carefully examined and the three names added to the classes of 1788,1789 , 1790." 
This young girl had been a mere child at the time of her sister's marriage, on which occasion she is said, in her admiration for Dr. Smith, to have pushed her way in beside him and stood for a while between the bride and groom.

Having fixed upon his choice, Dr. Smith determined upon asking of her parents her hand in marriage. The letter by which Dr. Smith addressed Sarah is so characteristic of the man, being such a rare combination of vehemence in love and straightforwardness in business, that it cannot be omitted here, and is as follows:

\section{SALLY :}

$$
\text { "Cornish, N. H., January 22, I } 794 .
$$

You will excuse the precipitancy with which I proceed in my endeavors to accomplish my connection with you. I expected last evening to have set off for Hanover this morning, and I could not endure the least uncertainty till I returned, therefore I discovered my wishes respecting you to your Sire and Marm last evening, and they have generously given me leave to marry with you.

I hope I shall never meet with your disapprobation. Transported with Joy and Expectation I am

\section{Your sincere Lover}

Nathan Smith.

Miss Sally H. Chase,

Cornish."

Clearly Sally had already been led to acknowledge a willingness to accede to his desire before her "Sire" 


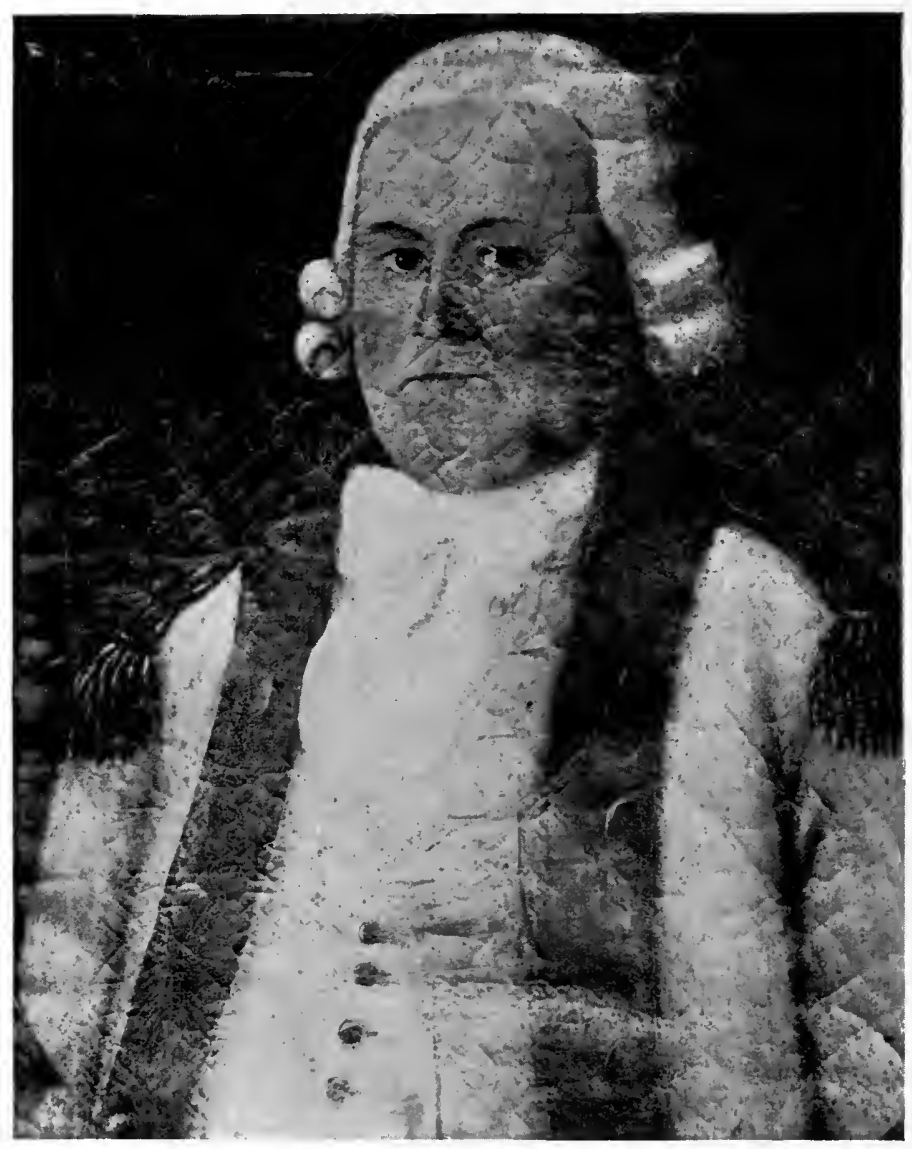

General Jonathan Chase

Father of Mrs. Nathan Smith 

and "Marm" were approached. Their consent having now been obtained, Nathan Smith and Sarah Hall Chase were married in September, I794, and this marriage proved a happy one in every way, Sarah being a true helpmeet in the home of her husband.

By his union with her Dr. Smith became connected with a large circle of New England families of prominence, although none of them were very rich in this world's goods. Sarah was the granddaughter of the Rev. David and Elizabeth Prescott Hall on her mother's side, and of Judge Samuel and Mary Dudley Chase on her father's.

The Chases had by this time acquired by thrift and economy what in that day might have been considered at least a competency. They had built substantial houses in Cornish, where they were able to enjoy great comfort, and had also extended their possessions in lands and promoted other settlements in their state. Dr. Smith, the only physician in the neighborhood, soon acquired a large practice, making his rounds to distant places either on horseback or by stage. On the 27 th of June, I795, a son was born to Dr. and Mrs. Smith, to whom they gave the name "David Solon Chase Hall Smith," all family names except the Solon, which came from Ossian,-evidently a favorite poet of the time,and this became the name by which this son was always called.

As a devoted husband and father, with a good practice and every prospect of happiness, it would have been but natural for Dr. Smith to content himself with life in Cornish, enjoying his domestic felicity. But the 
feeling that fellow beings were suffering and dying on account of the prevailing ignorance of the science of medicine, gave him no rest, knowing as he did that numbers of ambitious young men lacked only the opportunity of acquiring good medical instruction to fit them, as educated physicians, to become blessings to humanity. 


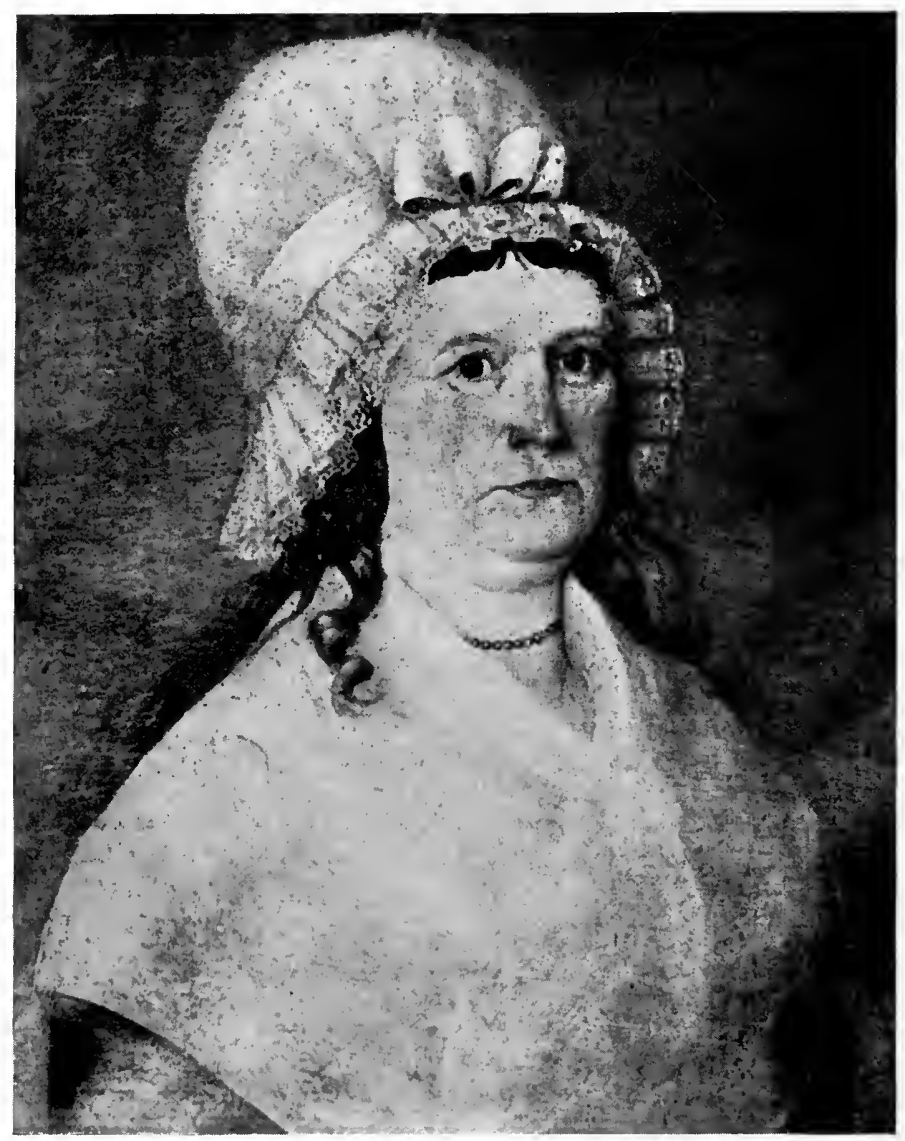

Mrs. Jonathan Chase

Mother of Mrs. Nathan Smith 



\section{CHAPTER FOURTH}

The Founding of the Dartmouth Medical School. Dr. Smith's Voyage to Edinburgh, Where He Continues His Medical

\section{Studies}

Strong in the determination to provide opportunities for this needed instruction, Dr. Smith applied to the trustees of Dartmouth College, at their annual meeting in August, 1796, for their approbation of a plan he had devised for establishing a Professorship of the Theory and Practice of Medicine in connection with Dartmouth. His plan was fully approved by President John Wheelock; the scheme, novel and far-reaching, was favorably received and discussed by the trustees, a resolution complimentary to the character and energy of Dr. Smith passed, and hope given for future encouragement; but it was voted to postpone final action upon the proposition for a year. This unsatisfactory response to his generous offer might have entirely discouraged an ordinary man, but Dr. Smith was only stimulated to new effort and determined to persevere in what he hoped might benefit many sufferers, for the only three schools then in the United States where medicine was taught were those of the University of Pennsylvania, the Medical School of Columbia College and the Medical School of Harvard College. 
In the absence of railroads, the distances to be traveled made it almost impossible for young men of moderate means to attend these schools, and one desiring to study medicine was compelled to apprentice himself to a physician who would instruct him in return for some menial work as office helper or farm hand. In consequence of the lack of proper instruction, few physicians of that day were at all qualified to attend the sick.

Dr. Smith, with his usual energy and far-sightedness, decided to utilize the months of waiting for the trustees of Dartmouth to accept his offer, by acquiring for himself more knowledge of his profession, and, in order to get the best instruction that could be had, he concluded to become a student at the University of Edinburgh, then one of the most noted medical schools of the world. Almost insurmountable difficulties beset this undertaking, for not only had he to part with his family, friends, and patients, but crossing the ocean in midwinter on a rather small sailing vessel was attended by many perils, and his very limited means made it necessary for him to borrow a greater part of the money to pay the way. His integrity of character was, however, so well established that the Hon. Sanford Kingsbury and other friends willingly loaned a sufficient sum to cover whatever part of the expense Dr. Smith himself could not provide.

Plans for the long journey were made with a view to the greatest economy, and every expense considered and eliminated as far as possible. The horse was sold 
and the proceeds used toward defraying the cost of the passage to Glasgow, this route being selected in preference to that by way of London because the price of the voyage to London was \$170, while Glasgow could be reached for $\$ 75$.

Great care and self-denial attended all the arrangements for this journey. He wrote to Dr. Lyman Spalding before sailing: "Respecting my voyage I am not so well provided for as I could wish, but must put my trust in God and not in filthy lucre." His farewell letters to his wife were full of tender solicitude for her and his little son, although he took comfort in knowing that they would be well cared for by her father and mother.

Just before sailing from Boston he wrote the following:

"On Board the Bark Hope, December I 7, I796.

Now for the last time, until I arrive in Europe, I address you. I have lately sent you two letters, which I hope you will receive without delay. I have in them expressed my love and constancy to you, and my tenderness for the dear little Solon. All my anxiety is for my family. I fear no danger but on their account. I have been very fortunate since I left home, all excepting some delay in sailing, which I do not much regret, as I have been able to procure letters and other advantages in this town which I should not have done if I had sailed immediately. Do, my dear, remember me. You are ever on my mind. I am sure I shall ever be happy 
if I live to return and find you and Solon alive and well. Do be careful of our dear little son. I shall keep you in mind, and hope to return happy. It is my constant prayer, and if good intentions can have any influence on our fortune, I am sure I shall succeed.

P. S.-We expect a fair wind in the morning, and a pleasant voyage. There are four passengers on board, all very agreeable. The vessel is as good and safe as ever sailed from Boston, a fine Captain and crew, all very obliging and civil. I lack for nothing to make me happy but your company, with Solon."

The bark "Hope" left with her five passengers, captain and crew on December I8, I 796. After landing and gaining what he could at Glasgow, Dr. Smith proceeded to Edinburgh, where for three months he attended the lectures of Monro, Secundus, on Anatomy and Surgery, and of Black on Chemistry.

A letter to his wife from Edinburgh shows the depth of his affection for his family and what a sacrifice he was making in separating himself from his home in order to accomplish the great work that he hoped to do for humanity. Evidently when he wrote the following letter his homesickness was so intense that he felt tempted to give up the struggle and return to America in the early spring, but his strong will and great ambition came to the rescue and he bravely persevered and eventually decided to remain abroad until September. 


\section{Addressed to Mrs. Sally H. Smith}

Cornish,

State of New Hampshire.

"MY DEAR SALLY:

I am quite homesick tho' very well on all other accounts. You cannot, and I hope you never will by similar experience, be sensible of the anxiety I have suffered since I left my home and family. Tho' I am every day surrounded with new and interesting scenes and am treated with great kindness and attention by the people here, yet my thoughts continually turn on you and our dear little son, whose name I cannot write without shedding tears on it. I imagine a thousand evils ready to befall him. I see him every night in my dreams and often wake myself by attempting to grasp him, but he always eludes my fond embrace and leaves me to mourn his absence. Do my dear, if he be still living, and I dare not think otherwise, do, I say, watch over him with maternal care, kiss him for me a thousand times each day and tell him that his papa is coming soon.

In my letter which I wrote you while in Glasgow I mentioned that I might not be at home till June, but I think now that I shall come sooner. I am now in Edinburgh, shall stay here but a few days, shall then go to London where I shall make but a short stop and then sail immediately to Boston. I have had no material misfortune since I came here; have become acquainted with the Medical Professors here, and am attending their lectures. I have a prospect of accomplishing my 
purpose to my mind. I have bought several books for your amusement, some of them written in the Scotch Dialect with an explanation which will give you a very just idea of the customs and manners of the Scotch people. Present my best Respects to your Honored parents, give my fondest love to your brother and sisters and remember me with fond affection to all our relatives and friends. Present my compliments to my pupils and inform them that I shall, God willing, be with them again in May or sooner. Remember me in particular to my brother and to every one with you in my home. I am, my dear Sally, yours with the fondest love and conjugal affection till Death, which God grant may be at a late day. Adieu, my dear, for a little.

Nathan Smith.

February 23, I797. Edinburgh."

While in Edinburgh, Dr. Smith purchased and "sent home to the college library medical books to the value of thirty pounds sterling and brought with him apparatus for anatomy, surgery, and chemistry which he deemed indispensable for commencing the proposed medical institution" and which he hoped the trustees of Dartmouth might purchase, as he "could ill afford to bear the expense himself."

After leaving Edinburgh, Dr. Smith spent three months in London, where he engaged in hospital work with eminent physicians, before returning to Boston on the ship "Apollo" early in September, 1797.

In this visit of nine months to older countries Dr. 


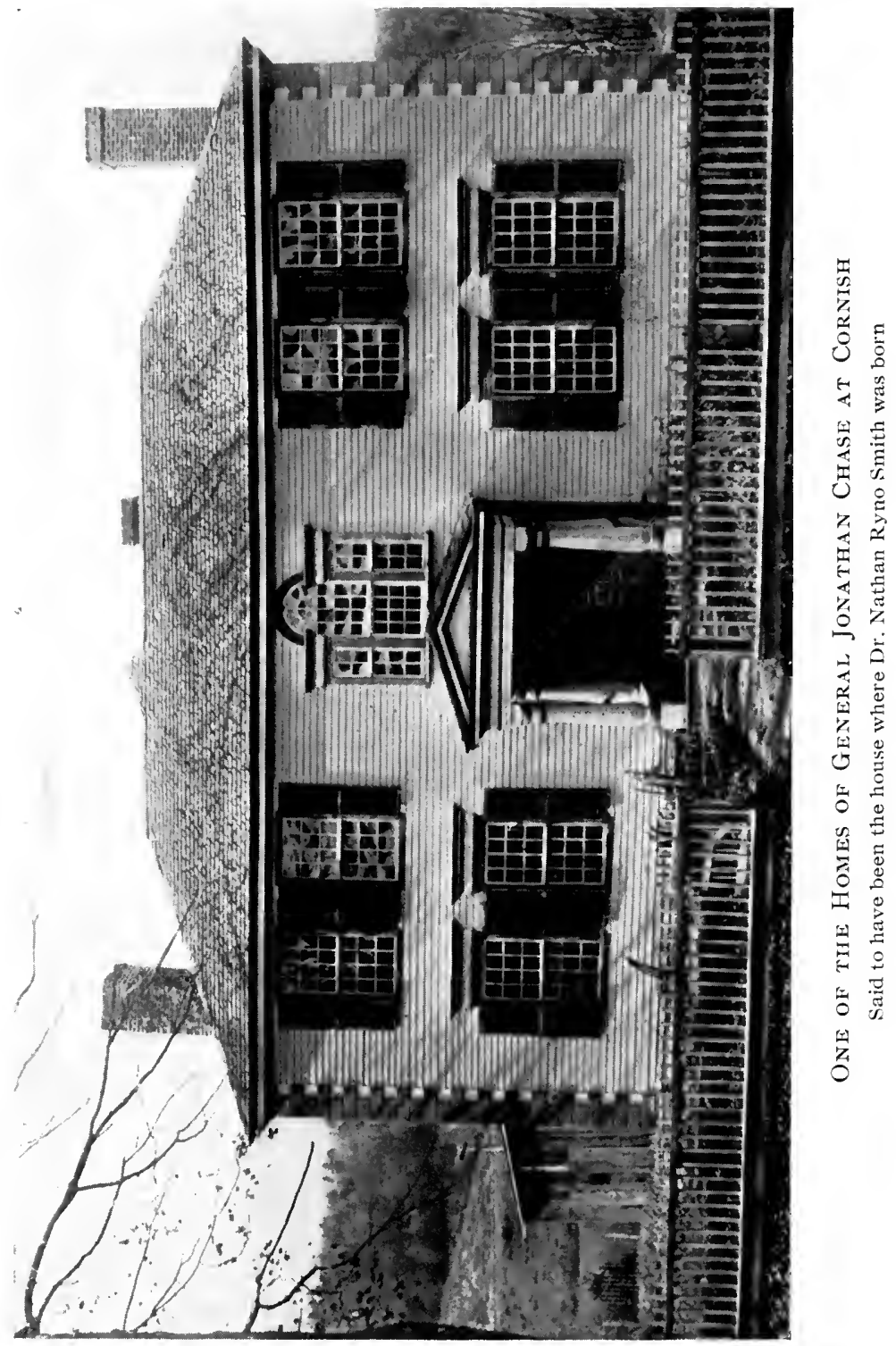



Smith acquired a great deal of valuable information on medical subjects as well as a broader knowledge of the world in general, and the good impression made by the enterprising young American upon foreign friends was attested by letters from them to other American physicians, as also by a diploma, which was sent to him in I 797 on his return, from the Medical Society of London, accompanied by a notice of his election as Corresponding Member of their organization.

On Dr. Smith's arrival at his home in Cornish he not only found his wife and Solon well, but he had acquaintance to make with a second son, Nathan Ryno Smith, a fine boy four months old, who was born on May 2I, I797. A pretty story is told of this happy meeting: When Mrs. Smith was preparing for the father's coming, she borrowed several babies from neighbors and made Dr. Smith select his own from among them, which he immediately succeeded in doing, for, as he said, he "picked for the prettiest." Although this son Nathan was his father's namesake, a name from Ossian's poems was again supplemented, and "Ryno" became the name by which he was always called in the home.

Not much time could be spared by Dr. Smith for the enjoyment of his family and home at Cornish, for he was obliged to go very soon after his arrival to Dartmouth to put into operation the plan for establishing the medical department, which the trustees of the college had decided to accept. 


\section{CHAPTER FIFTH}

Both taste and good judgment were shown by Eleazar Wheelock and his little company, when in I 770 they selected the site of Hanover for the Indian and American College of Dartmouth. The land about it was fertile, the climate very healthful, the scenery around the high plateau upon which it is built exceedingly varied and picturesque. In one direction between the branches of the lofty elms and pines were opened up vistas of still higher hills, and valleys so deep that, in ascending from them, the cattle, as they grazed, made circuitous paths as in mountain districts. From another point could be seen the beautiful Connecticut River, which in its windings formed the boundary line between New Hampshire and Vermont, and not only added variety to the wonderful scene, but brought many practical gifts and privileges of great value to the new settlement.

No wonder that a place so full of natural advantages, and a knowledge of the energy of those pioneers in undertaking the education and civilization of Indian youths, appealed to the generosity of many noble men and women and made them willing to help on the good work by their donations, until, during the twenty-six years which elapsed between the founding of the college and the offer of Dr. Smith to establish the medical school in connection with it, the reputation of the institution had spread over the country, and Dartmouth had 

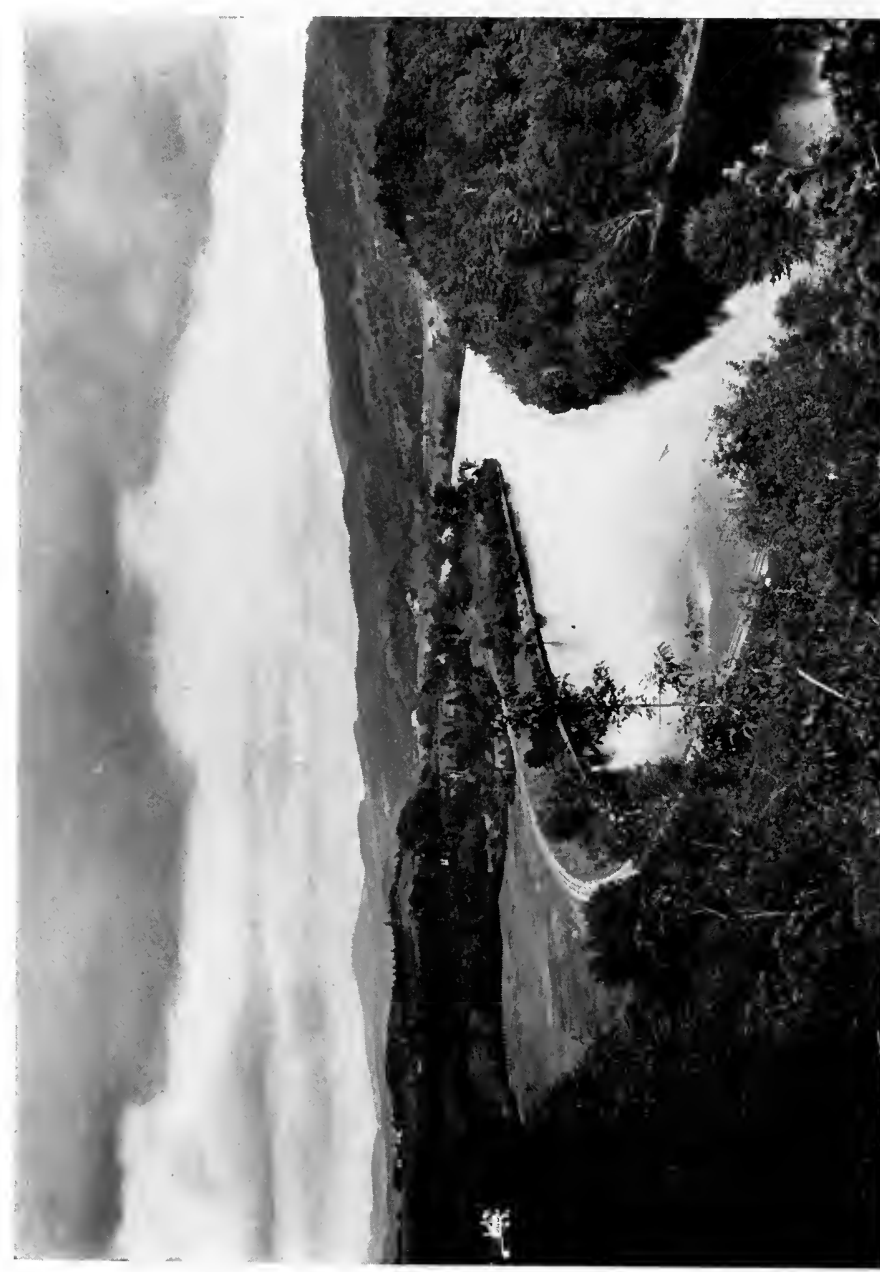

ב 

become recognized as one of the best colleges in the United States.

But in those early days it was not in the power of the most generous to give largely, for the early inhabitants of the country were poor, and even the best of schools had to struggle for the means to erect suitable buildings to carry on its work, and this, the first college of New Hampshire, was no exception to that rule.

"The first full course of Medical Lectures was delivered by Dr. Nathan Smith at Dartmouth in the Autumn of $\mathrm{I} 797$ before his election as Professor." Dr. Oliver P. Hubbard in his "Historical Discourse" at Dartmouth, from which the writer of this history largely quotes, says that "in August, I798, the plan proposed by Dr. Smith in 1796 was adopted by the Trustees, and he was appointed a Professor, 'whose duty it shall be to deliver public lectures upon Anatomy, Surgery, Chemistry, and the Theory and Practice of Physic.' A complete schedule was prescribed as to the course of lectures and the conditions of study and graduation, and the degree of A.M. was conferred on Dr. Smith, while that of M.D. only came in I 801 . The fable of the emergence of Minerva fully armed from Jupiter's brain is hardly more remarkable than the complete evolution of this school, and the placing of it on the shoulders of one man."

Dr. Smith's great skill and energy and his faithfulness to duty carried forward the work of this, the fourth medical school of the country, with such surprising success that students came in numbers to be under his instruction. 
In August, I 798, two young men received the degree of M.B., one of whom was the afterwards noted Dr. Gallup. The degree of A.M. was at the same time conferred by the trustees upon Dr. Smith.

But notwithstanding the phenomenal growth of the Medical School at Dartmouth carried on by one man, Dr. Smith's trials and discouragements were so great that few men thus situated would have persevered in the undertaking. Having no salary from the college to help towards the expenses of the school or the support of his family, he was dependent upon the small pay then exacted from medical students and the meagre returns from his practice, which, although extensive, was far from lucrative, and had to be attended under difficulties, on horseback, over bad roads, and often in inclement weather both in winter and summer.

The accommodations for the medical department were also small and inadequate. Dr. Hubbard says that tradition points to "a small two-story house of four rooms" as its first home, and in August, I 799, the trustees devoted and fitted up, for Dr. Smith's lectures, Room No. 6 in the northeast corner and first story of Dartmouth Hall-a building which, during the hundred years of its existence, by its beauty and suitability well repaid the "long agony of effort" which its erection is said to have cost.

But no inconvenience of surroundings prevented Dr. Smith from persevering in his noble work. He not only taught faithfully and attended untiringly to his large practice, but he kept in touch with physicians of 
the large cities, and was ever ready with keen interest to avail himself of new discoveries.

Jenner published his great work on Variola Vaccine in London in 1798 , and to Dr. Benjamin Waterhouse is given the credit of being the first to practice vaccination in the United States, for he is said to have vaccinated his own family on July 8, I 800 ; but, if not the first, Dr. Smith and his pupil, Dr. Spalding, were certainly not far behind Dr. Waterhouse in adopting the use of vaccine, for, under date of Hanover, August 25, I 800 , Dr. Smith wrote to Dr. Spalding: "I have to acknowledge the receipt of two letters from you since I wrote you and am under great obligation to you for the kine-pox infection which $I$ received in your first letter. I have always been of the opinion that we should arrive at such a degree of knowledge about the kine-pox as to make it a substitute for the small-pox and attributed our failure of it in several instances to our ignorance of the proper mode of communicating it. I have used some of the infection that you sent me. I have never subjected any of my patients to the infection of the small-pox."

This letter with its date clearly shows that before August 25, 1800, Dr. Smith had been practicing vaccination.

Among Dr. Smith's very old ledgers, containing heads of his lectures, there is one marked Hanover. On the inside of the cover is pasted the very plain book plate shown on a following page. 
And on the first blank fly leaf he has written:

Heads of Lectures. Anatomy.

Nathan Smith M.D.-C.S.M.S. Lond.

\section{Prof. Medicine Dartmouth College \\ New Hampshire.}

Throughout the book, the paper and ink are in excellent preservation. The writing is evidently intended for his own eyes alone, for it was rapidly and vigorously penned to serve as suggestions in his extemporaneous manner of delivering lectures.

The first lecture is on anatomy and gives the Greek derivation of the word, and, as was Dr. Smith's custom in all that he did or said, he commenced at the very foundation of things and traced the history in outline along from the ancients to the day in which he was lecturing. He found the era of philosophy beginning with the Ionian Thales in 480 B. C. Socrates, the seventh in succession, introduced the study of morals, bringing down philosophy from Heaven to make men truly wise. "Plato was his scholar, and by his writings we see that he had studied Anatomy. He said that 'the heart was the knot of the blood vessels, and that the blood was the food of the flesh.'

"Hippocrates was nearly contemporary with Plato, -about 400 B. C. From the time of Hippocrates to Galen, who flourished about the second century in the 


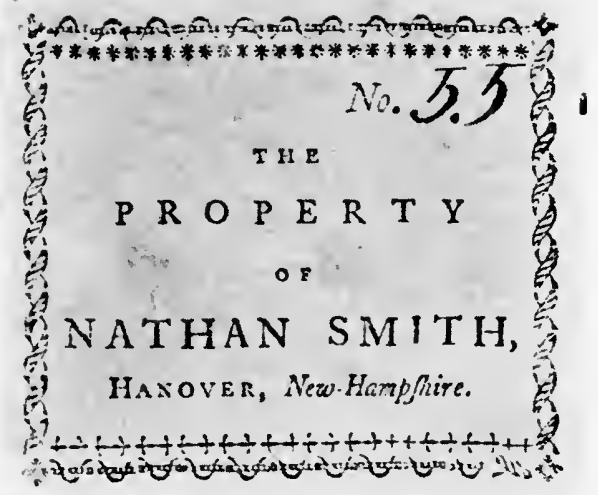

The Book Plate of Dr. Nathax SMith

Photographed from the one in his ledger of 1800 

decline of the Roman Empire, a space of six hundred years, anatomy was greatly improved. These two great men raised the credit of natural knowledge and spread it as wide as Alexander's Empire. Civilization and improvements of every kind are thought to have begun in the fertile countries of the East. ...

"It does not appear from the history we have of the Jews, who went out from Egypt when that country had arrived at considerable improvement in other arts and sciences, that they had much knowledge of anatomy.

"We read of physicians, but how or in what manner they were instructed, we have no account of, and, if we may judge from some of the Jewish ceremonies which were observed in preventing and curing disease, we shall conclude that the rational system of physic was not then taught. Witchery and marvelous applications being in vogue is a sufficient proof of their ignorance in natural knowledge.

"We read that Samuel hewed Agag to pieces, but we do not learn that he did it to acquire anatomical knowledge. On the contrary we are informed that he did it in obedience to a Divine Command."

This interesting introductory lecture is continued in rather unfinished sentences and clauses, and naturally, being hurriedly penned, some of it is difficult to decipher, but all that Dr. Smith ever wrote or said showed not only deep thought and study, but a direct and perfectly original and interesting way of imparting information, often adding to sound teaching the spice of wit.

A lecture on osteology follows the introductory lec- 
ture on anatomy, and then a general description of the human body, etc.

Lectures on physic follow those on anatomy and then come a number of lectures on chemistry. At the back of the book Dr. Smith carefully recorded the names of his pupils under the heading "Catalogue of the members of the classes who attended lectures in 1800 and I 801." These lists are here appended with a photograph of one of the pages.

Seniors for 1800

Josiah Noyes

Nathaniel Shattuck

Daniel Parker

Elisha Hotchkiss

Daniel Campbell

Thomas A. Merrill

H. W. Fuller

Ephraim Simonds

Freeborn Adams

Asahel Stone

Matthew Taylor

Abner Howe

Caleb J. Tenney

Simeon Lyman

Daniel Webster

James H. Bingham

Elihu Smith

Lemuel Bliss

Ebenezer Janes
Juniors for 1800

Elisha Rockwood

Amos J. Cook

Moses M. Fisk

Amos Twitchell

Josiah Moulton

Samuel Whitmore

Nathaniel Huse

Joseph Richardson

Joseph Paine

Samuel Eastman

Augustus Alden

Daniel Phelps

Nathaniel Dutton

John Frink

Jacob Gillett

Joseph Mulliken 
Allatalogne of the menter of

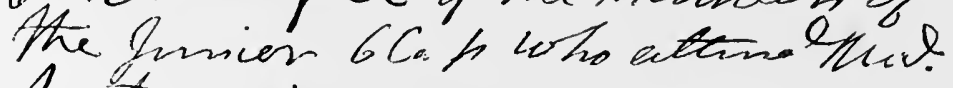
Qutars is 1801

Xuther bliafiniensmaid

$x$ Furertiens pestimarn haid Siare Gavain.

fonesthens Gulmove

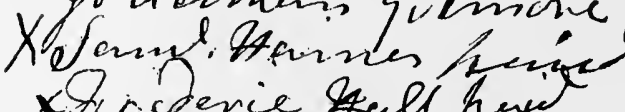
$x$. r. Derie ffull hurid $x$ ftemry Auklardencid

$x_{0}$ Vhernish Anstingtos Baid.

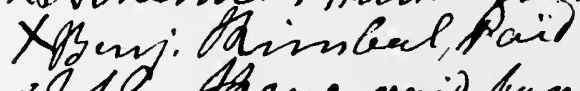

$x$ Coth theyer reid by not

* frying houstiris

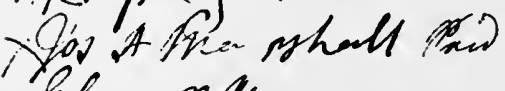

Glecurationza

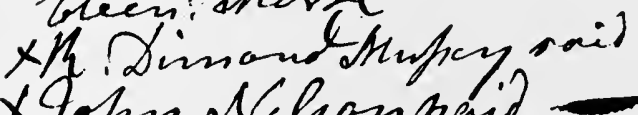

X John aVchoustiaid

Juhnon is ye thai)

$x$ ECmon tiester havd

Photograph of a hage from . An Smiths ledgen heept at Dartmaith in 1800 V 1801. 

Catalogue of the Members of the Senior Class who attended Medical lectures in I80I.

Amos Cook Cutting Brown Emerson Elisha Hammond Joseph Richardson Rockwood

Amos Twitchell Samuel Walker Samuel Whitmore Roswell Willard Nathan Wood
Catalogue of the Members of the Junior Class who attended Medical lectures in I8OI.

Luther Chapman

Jonathan Eastman

Isaac Garvin

Jonathan Gilmore

Samuel Haines

Frederic Hall

Henry Hubbard

Nehemiah Huntington

Benjamin Kimbal[1]

John Keyes [Keys]

Vryling Lovell

Joseph A. Marshall

Eben ${ }^{r}$. Morse

R. Dimond Mussey

John Nelson

Salmon Nye

Thad [d] eus Osgood

Edmun[d] Parker

Samuel Peabody

Augustus Peabody

Jeremiah Perley

Samuel Phelps

John Porter

Experience Porter

Silas H. Sabin

George Shattuck

John B. Storey

Enoch E. Tilton

Nathan Weston

Luke Wood

Jabez Woodman

Storrs

Azor Moody

Jesse Billings 
These lists show conclusively that the Dartmouth Medical School was already in a flourishing condition in the year I 80r, when Dr. Smith's only assistant was his pupil, Dr. Lyman Spalding, whom he employed at his own expense to give three courses of lectures on chemistry and to help him somewhat with his practice.

So many of the students here mentioned became eminent in the medical profession, that comment is scarcely needed to certify to the excellence of the instruction which they must have received from Dr. Nathan Smith, and it has been said that no one could have come under the strong personal influence of a man so attractive, so wise and so exemplary in character, without having ambition stirred and a lasting impression for good made upon him for life.

Among these students of $\mathrm{I} 800$, the man who became most distinguished in the history of the country was undoubtedly Daniel Webster, ${ }^{2}$ but the names of Josiah Noyes, Amos Twitchell, Phelps, Peabody, Emerson, Mussey, Shattuck, and, indeed, nearly all here enumerated, are familiar as eminent either as physicians or men of letters among the early settlers of the country.

In I80I, Dartmouth again honored itself in conferring upon Dr. Smith a second degree-this time that of M.D., a degree then by no means common. Up to within four years of this time Yale had conferred this as an honorary degree upon but seven physicians, two being foreigners. (See Welch, note I3.)

But it was evident to Dr. Smith that, if the school

2 Daniel Webster probably took only chemistry or one or two branches. 
were to go on increasing in numbers, more space must be secured and aid must be had to supplement his small private funds. $\mathrm{He}$ therefore made personal application, in 1803 , to the Legislature of New Hampshire, which resulted in an appropriation of $\$ 600$ for medical apparatus, and in the same year the trustees of Dartmouth College provided another room adjacent to No. 6 already given, which two rooms served for lecture hall, dissecting room, chemical laboratory and library.

In addition to his arduous work in conducting the Medical School at Dartmouth all alone during the winter months, Dr. Smith received a number of students at Windsor, Vt., which adjoins Cornish, and gave them private instruction in medicine in summer. Evidently Dr. George C. Shattuck, who had already received his degree of M.B. at Dartmouth, had some intention of taking the summer course, as the following letter must have been in answer to one from him inquiring about terms, etc. :

"Windsor, July I 2, 1804.

To Dr. George C. Shattuck.

Sir :

Respecting my terms for tuition I have of those who have been educated at College, I33 dollars for tuition, deducting from that what they have paid for tutors while in College. I am now situated in Windsor, Vt., have perhaps as good accommodations for Students in the neighborhood as I had at Hanover. I have with 
me now nine medical students and shall in time to come give a private course of lectures on theory and practice every summer over and above my public course. Respecting the time of payment, I have generally accommodated my students as to time \&c. If you should conclude to study with me, I will do all in my power to promote your studies. I am with respect

Your friend and servant

Nathan Smith."

One month after this letter was written, a proposition came to Dr. Smith from Dartmouth which enabled him to concentrate his efforts in teaching in one locality. In August, I 804, the trustees voted Dr. Smith a salary of $\$ 200$ per year, on condition that he should remove his family to Hanover from Cornish, which, on account of straitened circumstances, he had been unable to do up to that time. Accordingly, early in the spring of 1805 , Hanover became their settled home and this obviated the necessity for Dr. Smith's constant journeys back and forth.

The interest excited by the instruction in this new department is curiously illustrated by an anecdote related to Dr. Hubbard by a gentleman who was, early in this century, an undergraduate in the college:

"President Wheelock came from Dr. Smith's lecture room to evening prayers in the old chapel, and gave thanks, in substance as follows:

" 'Oh, Lord! we thank Thee for the Oxygen gas; we thank Thee for the Hydrogen gas; and for all the 
gases. We thank Thee for the Cerebrum; we thank Thee for the Cerebellum, and for the Medulla Oblongata.'

"Isaac Patterson, Esq., Bath, N. H., Dartmouth, I 812 , confirms this as occurring in 1810 , in letter, October I3, I 879." 


\section{CHAPTER SIXTH}

\section{Friendship of Dr. Smith with His Pupils Letters to Dr. George C. Shattuck}

Friendship between Dr. Smith and his pupils did not end with their student days at the Dartmouth Medical School, but with many of them great interest and strong attachment continued through life.

As has been stated, Dr. Lyman Spalding ${ }^{3}$ became his assistant, living for a time in his house, and Dr. Cyrus Perkins ${ }^{4}$ was selected by him to fill the chairs of Anatomy and Surgery in I 8 Io, when ill health from overwork made it necessary for Dr. Smith to give up a part of the great burden of the school. But perhaps no one of his pupils was ever nearer or dearer to him than Dr. George C. Shattuck. ${ }^{5}$ Their correspondence was constant when apart, and many of Dr. Smith's letters were preserved by this warm friend, who was ever ready to aid his beloved preceptor, often no doubt

${ }^{3}$ Lyman Spalding, from his boyhood days at Cornish, was the admirer and emulator of Dr. Smith. He had secured his M.B. at Harvard in 1797, taking a similar degree at Dartmouth in 1798, and these were followed by an M.D. from Dartmouth in 1804 and the same from Harvard in 1811.

4 Cyrus Perkins, Dartmouth A.M. 1800; also Harvard 1823; Dartmouth M.B. 1802 ; M.D. 1810 ; also Harvard 1823.

5 George Cheyne Shattuck, Dartmouth A.M. 1803; also Harvard 1807; Dartmouth M.B. 1806, M.D. 1812; also Bowdoin M.B. 1851; Dartmouth LL.D. 1853; 1846-1852, president Massachusetts Medical Society. 
at the sacrifice of his own time and interests. Long after the death of both of these good friends, the family of Dr. Shattuck, no less kind than he, sent Dr. Smith's letters to his grandson, Dr. Alan P. Smith of Baltimore. One of the earliest, bearing the date Hanover, January 22, I806, is in answer to a letter from Dr. Shattuck, who, after graduating at Dartmouth, had gone to the University of Pennsylvania for a special course under the then famous Dr. Rush. The address is simply

\section{"To Dr. George C. Shattuck, Medical Student, Philadelphia,"} and reads as follows:

"Dear Sir:

Your favor of the $25^{\text {th }}$ ult. was duly received. I rejoice that you are so happily situated and that your opportunities of acquiring information equal your former expectations. Dr. Rush ${ }^{6}$ must be a very interesting lecturer. As to his classification of diseases I do not think it very material. However we may class diseases we must study them in detail. I have observed that men of genius, having accustomed themselves to view objects in certain relation to each other for some time, consider their relations so obvious as not to escape the notice of the most inattentive observer,

${ }^{6}$ Dr. Benjamin Rush died in 1813. He was not a surgeon of note, but a distinguished teacher and general practitioner of medicine. 
when in reality their reasoning is too arbitrary to be followed without much study and attention. This has generally been the case with nosologists, and perhaps Dr. Rush's method of classing diseases is not wholly exempt from arbitrary reasoning. I cannot see how nosology is essentially benefited by adding the word 'state' to the name of diseases, as the pleurisy state, rheumatic or hydrophobic state of fever. It is no new discovery that those diseases are attended with fever, and the word pleurisy, rheumatism and hydrophobia give us as much information respecting the disease, without the word state, as with it. As to the unity of disease, you know it is my opinion that we have in medical science of late generalized too much and that the progress of medicine has been checked by it. This mode of proceeding tends to substitute idleness for industry, and dogmatism for patient inquiry. Metaphorical reasoning in a lecturer will have one good effect,-young men are always fond of tracing resemblances, and if they do not carry them from the truth, such reasoning will tend to engage and fix their attention.

Since you left this place I have suffered a prodigious loss of books. On getting my library together since the close of last year's course of lectures, we find that 22 No.'s of the Medical and Phy. Journal, Med. Museum and Med. Repository are missing, with about 20 Vols. of other books. I have since brought my library into my own house and suffer no one to take a book without my knowledge.

I have lately amputated successfully in Montpelier; 
the subject was a boy seven years old, the disease a white swelling in the knee.

I congratulate you on obtaining a Royal Stone medal, and am with the sincerest regards for your happiness and prosperity,

Your humble servant,

Nathan Smith.

Hanover, January 22, I 806."

This letter is especially interesting as giving the opinion of one of the greatest teachers of medicine of that day about the methods of another equally distinguished. It also tells of Dr. Smith's loss of valuable books from his library when it was almost impossible to replace them, there being no bookstores nearer than Boston, and even there rare books were often not to be found. The theft, or even the mislaying, of the books so needed in the work of Dr. Smith, who was willing to sacrifice his own time and comfort in the effort to instruct others, seems more than an ordinary offense.

As has been shown, there never was a man more opposed to a faulty education for a physician. $\mathrm{He}$ fought ignorance and the improper treatment of the sick, and waged war openly upon quackery, which was to him an abomination. As early as in 1808 , he wrote to Dr. Spalding thus: "I wish you to write me when the next annual meeting of the New Hampshire Medical Society will be holden, and where. I have an intention to attend if possible. I intend to renew the effort 
to obtain an Act of the Legislature to discourage quackery. You know I'm not easily beaten down in my projects, and, though sometimes slow in execution, yet keep the object in view. The business was not judiciously managed this year. I was out of town when the questions were tried and I'm confident that more than half the members did not understand the matter. Several of the members have solicited me to renew the application. I shall attend the General Court solely for medical purposes at their next session."

At a meeting of the New Hampshire State Medical Society in May, 1807 , it had been proposed by Dr. Spalding and voted that a resolution to prevent quackery be offered to the State Legislature,-no physician to be qualified for practice unless a graduate from a respectable university, and no medical man not so qualified to have legal power to collect debts.

The next eight letters, all written to Dr. Shattuck between 1807 and 1810 , are introduced here in a group and almost without comment, as they speak for themselves, telling of the perseverance of Dr. Smith in carrying on his practice in medicine and surgery, while working under difficulties to establish the Medical School at Dartmouth. There were then no apothecaries anywhere near, and acids and other drugs had to be brought by stage from a great distance, instruments made by a tinman in Boston, to order, after drawings found in books, and necessary herbs and plants derived from the gardens of friends in Salem and Newbury.

It was early in the year 18098 that Dr. Smith, at 
great expense to himself, secured the services of Dr. Alexander Ramsey, ${ }^{7}$ whom he considered the best anatomist in America, to give a course of lectures on anatomy in the school. With the highest appreciation of the good work of others and perfect freedom from professional jealousy, Dr. Smith wrote to Dr. Shattuck that Dr. Ramsey had begun a new era in the college, and put it in his power to do more in the science of anatomy than he knew how to do before.

In this course of lectures, Dr. Spalding showed himself invaluable not only as assistant in demonstration, but also in bringing from Portsmouth much-needed material for illustrations, etc.

Perhaps these lectures and the presence of his valued friends filled Dr. Smith with more enthusiasm than ever for the advancement of the interests of his institution, for about this time he again made personal application to the Legislature of New Hampshire for an appropriation towards building a suitable home for the medical school.

In I 809 , the sum of $\$ 3450$ was granted to him to erect a building of brick or stone for its accommodation, but again a condition was made and this time it

7 Alex. Ramsey, anatomist, 1754-1824, came to this country about 1800 and delivered a short course of lectures on anatomy and physiology in Columbia College. He possessed much profound learning, but his vanity, arrogance and pomp, combined with his grotesque person, interfered with his success as a teacher and won him the name of the "Caliban of Science." $\mathrm{He}$ adopted the theory that the bite of a venomous snake was rendered innoxious by alkalies and died from the results of an experiment on himself.-National Cyclopedia of American Biography. 
was that he should "give a site for it and assign to the State his Anatomical Museum and Chemical Apparatus." Dr. Smith had hoped for a much larger sum, and found it necessary to supplement this grant by over a thousand dollars, with the hope that it might be refunded to him later. But his generosity was as unbounded as his love for his fellow men. He gave the site in 1810 , and afterwards, finding the first situation inconvenient, "he conveyed to the State of New Hampshire forty-five square rods,"-the site now occupied. A building of brick was erected, seventyfive by thirty-two feet, having two commodious lecture rooms in the two-story centre, and two three-story wings for library, chemical laboratory, museums, etc.

Dr. Hubbard, in his most interesting Historical Discourse, describes the enterprise of Dr. Smith as unprecedented, in attempting, all alone and in face of almost insuperable obstacles, to found a medical school, when that at Harvard, the first college of New England, was being sustained with difficulty under the ministrations of three eminent and learned men.

Dr. Smith's letters to Dr. Shattuck, who was now in Boston, show in a small degree how he triumphed over some of these barriers, even when hampered at times "with the weight of business and with very ill health," which he concealed as much as possible for fear of alarming his friends and his class.

The letter of November 28, I 808 , will be particularly interesting to the profession, as it gives at that early day some of Dr. Smith's independent views in regard to cancer and necrosis. 


\section{Dear Sir :}

"Hanover, September I 5, r807.

Respecting our doings at our last Commencement I conclude you have discovered that the Board of Government gave no doctor's degree in Medicine. Dr. Thatcher was not formerly proposed the last year, and by a law of the Board, no honorary degree can be voted without the candidate has been proposed by some person at sitting of the Board preceding. Dr. Thatcher now stands proposed and will probably be honored by a degree at our next meeting. ${ }^{8}$

I have been pestered with a number of letters from several persons, in and about Boston, who appear to have made very great exertions to obtain a degree for a Dr. Barnes of that place. In a letter to a Mr. Hill, one who wrote in his favor, I referred him to you to learn the requisites for a degree at this college, but instead of bringing any word from you, I received several certificates signed by several persons in Lynn and in Boston in his favor but none of them appeared to come exactly to the one thing necessary, and we thought best to postpone the business for that time. I wish, if it would not be too much trouble, that you would try to ascertain the situation and merits of Dr. Barnes, and let me know that I may know how to answer their importunities.

I wish also that you would apply to Mr. Dunn or

8 The honorary degree of M.D. was conferred in 1810 upon James Thacher, surgeon in the Revolutionary Army, and author of "The American Medical Biography"; but the Dartmouth catalogue gives no evidence of Dr. Barnes having been honored with a degree. 
Mr. Maynard, whom you think best, and procure of them on my account several things, viz: One dozen oil flasks and a pound of each of the following, and in as great a degree of purity as they can be obtained:

Nitric Acid.

Muriatic Acid.

Sulphuric Acid.

I will send by Mr. Pool or some other person from Hanover for the goods.

I wish also, that if they can be obtained in Boston, that you would procure for me some earthen and glass retorts.

I am with sentiments of esteem,

Your Friend and Servant,

NAThan SMith.

To Dr. George C. Shattuck, Boston."

\section{"Dear Sir:}

Mr. Church,- the bearer, wishes to be acquainted with you. Mr. Church has been with me one year. You will find him a well-informed, honest man. Any favours you are pleased to bestow on him, will oblige me.

Respecting the subject of your last letter, you may inform those who make it their business to take care of my concerns, that I will thank them to exhibit any demands against me for tuition etc. Respecting Dr. 
Warren,-I payed him his money with interest when he called for it; he was kind enough to wait on me a long time, I suppose because he thought his money safe and at interest.

I have a prospect of procuring a very handsome set of anatomical preparations in season to use them the ensuing course of lectures; if I succeed, I shall have a better collection than there is this side of Philadelphia. I have proceeded some lengths in my dissertation on Cancer etc.

I am with sentiments of esteem and sanguine hopes of success,

Your sincere friend and humble servant,

Nathan SMith.

Hanover, November, 1808 .

To Dr. George C. Shattuck, Boston."

Dear Sir :

“Hanover, November 28, I 808.

I fear I have not in my observations on cancer and scirrhus, been so particular in some parts of it, as I should have been respecting the definition of the word 'Scirrhus.' If that word means only a diseased gland, I am incorrect, or rather the definition is defective, for, from the cases I have related, it appears that a Scirrhus tumor often arises in a part of the body where there are no glands of any kind situated, unless you allow the cells which contain the fat in the adipose membrane that office, and even then we find cases 
which begin in the bone itself, which can hardly be considered as glandular.

Another point perhaps I have not sufficiently insisted on, - that is, that when cancer begins in any particular part of the body and if it produces its likeness in another part of the body it is in a similar part, viz: if it begins in a bone it will next appear in some other bone, or if it begins in the cellular substance, it will next appear in some other part of the cellular substance \&c. This happens also in other diseases. In necrosis, or that disease of the bones which is called in this country 'fever sore' the disease is not always confined to one bone; indeed if the disease is extensive, and especially if it is illy treated in the part first attacked, it generally appears in some other bone and runs the same course as in the first. I believe we might point out many diseases which serve to confirm the doctrine I have espoused.

I fear too, that I have not explained myself suffciently on the question respecting cancer being a general or local disease. I think, however, it will appear that I consider it often as a general disease.

If you have time to make any alterations in what I have written in either of the points above pointed out, I wish you to do it, but I fear you had it too late and that the thing will be found too imperfect to make anything of it this year; if so let it lay over, we can do something with it hereafter. I wrote it under very great disadvantages. I had to struggle with a weight of business and with very ill health for two months past; till within a very few days, I have been wretched 
and more than half the time in torture with an affection of my stomach, which I have concealed as much as possible that I might not alarm my class, which is very numerous and respectable, and alarm my friends; but $\mathrm{I}$ had almost determined to yield to the complaint, when, on a sudden, after taking some pretty powerful medicine several days since, my complaint seemed to leave me, and this is the first evening which $I$ have felt like myself for more than two months.

Dr. Ramsey has commenced his lectures with much applause and I think him a very able anatomist. Being relieved from anatomy I shall be able to do better justice to the other branches so that Dartmouth will not sink this year.

Your sincere friend,

Nathan Smith.

If I have my health I shall be able to furnish a paper for Dr. Boylstone in a few weeks.

Dr. Shattuck, Boston."

Dear Sir :

"Hanover, December 31, I808.

Permit me to make you known to my worthy Friend and Benefactor, Dr. Alexr. Ramsey, who will pass through Boston on his way to Philadelphia. Dr. Ramsey has just closed his course of Lectures in this College which have been delivered much to the satisfaction of all concerned. Dr. Ramsey has begun a new era in our 
College as relates to Anatomy and Physiology, and has put it in my power to do much more in that science than I knew how to do before.

I wish, if it can be consistent, that you would contrive to bring Dr. Ramsey acquainted with Mr. Boylstone, who seems to have the improvement of medical science in view.

I am now projecting a scheme to procure a building for medical purposes at Hanover. I expect to be in Boston in the course of next month and will then acquaint you with all my plans relating to the advancement of our infant, but somewhat thrifty, medical institution. I am with sentiments of the warmest friendship, your old friend

\section{Dr. G. C. Shattuck,}

Nathan Smith.

I 3 Middle St.,

Boston,

Massachusetts."

"Sir :

I have written a letter to $\mathrm{Mr}$. Thurston of Newbury, requesting him to pay you twenty-five dollars, and have directed Mr. Aspinwall, who will hand you this, to leave the letter with you, and must request you to take the trouble of calling on Thurston for the money, if he should be in Boston, as I think probably he may be; if not, be so kind as to send the letter to him and let him know where he may direct to you. Mr. Aspinwall is a pupil of mine and will return 
directly here; if you have any communication to make to me you may do so by him.

I am, with sentiments of esteem,

$$
\text { Yours, \&c., }
$$

Nathan Smith.

Hanover, March 16, I809.

Dr. G. C. Shattuck."

"Sir :

I am continually troubling you about many things. I wish now that you would be so kind as to procure for me, two tin reflectors and a tin canister, which you will find described in Henry's Chemistry, in his chapter on Caloric. If you can find a tinman who will make them for you, and you will transmit them to me by Mr. Williams or Mr. E. Woodward, it would oblige me very much. I shall soon be able to transmit to you the means of paying for these things.

If you have a man in Boston who makes thermometers, and if he can do it, I wish also to have an air thermometer constructed according to Henry's directions in his chapter on Caloric. I presume you can find that book in Boston, and the workman may follow that in his work.

I have a patient here from Boston, a Mr. Darby, who has cataracts. I have operated on one yesterday with very flattering prospects of success.

If no other opportunity should offer I wish you would send these things by the stage; if they were 
carefully put up and sent by the mail and the driver well charged, I think they would come safe to hand.

I am, with sentiments of esteem,

Your Friend and Servant,

Nathan Smith.

To Dr. George C. Shattuck, Boston.

October, I 809."

"Dear Sir :

Since writing to you last, Colonel Graves informed me that a man by the name of Howe, a tinman living near Boston Stone, will make the instruments of tin which I wrote for, extremely well, as he can give a very high polish.

The reflectors I wrote for, you will find described in Henry in his chapter on Caloric, 28th page. They should be twelve inches in diameter and segments of a circle or sphere of nine inches radius.

The canister you will find described on the next page; it says polished block tin, six inches square, and I wish also that you would send me a little tinfoil.

We have commenced our course of medical instruction in this place. I do not know how many students we have, as I have not yet taken a catalogue, but have already over fifty medical students and fifty or more from the College, making in all a little more than an hundred.

Mr. Darby's case still appears very promising. $\mathrm{He}$ had not the least pain or soreness in the eye more than 
forty-eight hours. I think there can be no doubt but he will see well.

I have lately become acquainted with a Mr. Henry Darby from Salem, who has gratuitously offered me whatever I may find in his garden that will be useful to me. I am informed that he has one of the best gardens in New England. This was what I wanted very much and shall make my calculations to profit by it. I will visit him in April or the very first of May next and shall spend my time there and at Boston and Newbury till the last of that month, with a view to possessing myself of everything pertaining to gardening and agriculture that may be useful in this part of the country.

Respecting the glass retort, you may send me two or three; the middling size is the best.

I am, with sentiments of esteem,

$$
\text { Yours, \&c. }
$$

Nathan Smith.

Hanover, October 4, I809. To Dr. George C. Shattuck, Boston."

"Sir :

I have written you two letters of late, and as $\mathrm{Mr}$. Woodward was going to Boston, I thought best to write you again and, in addition to what I wrote for before, I want you to procure for me, one quarter of an hundred of red lead, sixteen pounds of mercury and about one gallon of winter strained lamp oil. The whole of those articles will be too much to send by the 
stage, but if an opportunity should not offer for sending them otherwise, I wish you to send me about half a dozen oil flasks by that conveyance. The remainder of the dozen I should like to have sent by the first team or when you send the other articles and should like it as well to have them sent full of oil as they come to hand. If opium is less than $\$ 1.50$ an ounce ask the apothecary to put up four ounces for me.

Mr. Woodward will speak with you respecting publishing some account of our medical affairs in this State, especially as respects the late grant for a Medical Building about which some of our people are making a political issue. Mr. Woodward will be able to inform you respecting the particulars.

I have already received several pupils for attending the opening course of lectures and have heard of a greater number than usual at this time who are calculating to attend. I feel very anxious to meet them and shall neglect nothing that I can do to render the institution reputable.

I am,

Your Friend and Servant,

Nathan Smith.

To Dr. George C. Shattuck, Boston.

October, I 809."

Pathetic indeed is the letter of May I4, I8 10 . For the first time in the history of Dr. Nathan Smith, we find his ardor for his work dampened and his great 
discouragement expressed. $\mathrm{He}$ had been willing to give his all to benefit his fellow men, but in return he found himself misunderstood and surrounded by such unpardonable ignorance and persecution as to make the situation almost unbearable. In his hour of deep disappointment, after a struggle of over twelve years to establish the Medical School, he wrote confiding to his friend his strong temptation to give up the battle.

On more mature reflection, however, this uncommon man put self aside, his benevolence conquered and he persevered again with his noble work. Some help was accorded, for it was in this year of 1810 that the trustees of Dartmouth for the first time employed an assistant for Dr. Smith, calling, at his request, his pupil, Dr. Cyrus Perkins, to occupy the chairs of Anatomy and Surgery, and this somewhat lightened the burden of the man who had for so long carried on the work of the whole school alone.

Dear Sir:

"Hanover, May I4, I8Io.

I have at length determined to leave Hanover, but at present have not concluded on any certain place of future residence. The political parties are so very jealous of each other in this State and so near a balance that I have nothing to expect from either, as some ignorant persons might be offended at any grant or assistance voted by the Legislature to promote what they term the 'cutting up of dead bodies.' No one will choose to advocate the measure and I expect they will, if not deemed too unconstitutional, revoke the 
grant made for that purpose last year, ${ }^{9}$ and, if that can not be effected, they will enact laws which will inflict corporal punishment on any person who is concerned in digding (?) or dissecting. If the thing should take this course it will afford me a good pretext for leaving the College and State,-a thing which will not be disagreeable to me. The proposal I made the State of giving land and the whole of my museum and apparatus was too much to give, but while engaged in promoting the school in this place I felt willing to go all lengths in sacrificing on the Esculapean altar; but the conduct of people and parties has cooled my ardor for laboring in my avocation in this place and determined me to sell my talents in physic and surgery to the highest bidder.

I shall attend the medical meeting at Exeter on the last Wednesday in this month and shall go from thence to Boston thro' Newbury and Salem. I propose to spend a week or two in Boston and shall then have an opportunity to converse with you on all subjects.

I am in haste,

Your Friend and Servant,

Nathan Smith.

Hanover, Monday, May I4, I8ro.

P. S.-You will not at present mention publicly my intention to remove from this place.

To Dr. George C. Shattuck."

${ }^{9}$ For the erection of the medical building. 


\section{CHAPTER SEVENTH}

Amid the difficulties and trials here described, more honors were awaiting Dr. Smith.

In his historical paper, kindly loaned to the writer by Dr. James A. Spalding of Portland, the following extract is found: "Dr. Smith having been chosen President of the State Society in I8II, was asked by Dr. [Lyman] Spalding, who was Secretary of the same Society, what he should announce on the program about the President's oration. Dr. Smith replied: 'You know what my habits have always been, viz., to deliver my sentiments on the nature and cure of diseases in as plain and simple a style as possible, and as this method has raised me to honor, and my pupils to a rank at least equal to any medical man's pupils in New England, I should not like to depart from my former practice. And especially as what I have to say will be confined to the theory and treatment of one or two diseases which can only interest medical men, I should not like to call it an oration, lest from the very name, I should be induced to play the orator.'"

Perhaps the recognition of his work and achievements manifested at this time in various quarters helped in a measure to cheer Dr. Smith, for, aside from his election to the presidency of the State Medical Society, the London Society, forgetful of its diploma presented in 1797 , sent a similar document, while Harvard conferred upon him the degree of M.D. 
These, together with the aid given by Dr. Perkins in the Medical School, and the exhilaration due to several notable cases of surgery, give a new tone to the letters of this year. Two from Worcester describe some very interesting operations. It is said that Governor Lincoln was on the point of resigning his office on account of threatened blindness, but that a successful operation by Dr. Smith for cataract enabled him to see again and continue his work as governor. Dr. Smith's joy and very pardonable pride over the success of his surgery at Worcester is really refreshing, and surviving friends and relatives of his still feel gratitude to the friends and patients who covered him with glory before he returned to the good people of Hanover, whose accusations of delay, etc., he dreaded might be awaiting him.

The money arrangements of that day seem to have been made principally by notes, promising payment; and these were handed about from one to another for collection. Dr. Shattuck was evidently Dr. Smith's chief reliance in place of a bank, for almost every letter to him contains some allusion to notes to be collected.

"To George C. Shattuck,

Boston.

Worcester, March I8, I8I I.

Dear Sir :

Today I have couched an eye for Governor Lincoln and one for a little daughter of Judge Paine of this 
place. Both operations were attended with the most flattering prospects of success. In the Governor's case the operation was exactly similar in all its circumstances to that I made on Mrs. Marston.

The little girl's case was a very interesting one. She had lost one eye by a former operation; her eye was very unsteady and the cataract membranous, but I contrived to fix the eye and to perform the operation in about two minutes with the most heartfelt satisfaction to all present. The little girl is about sixteen years old, a lovely child and very sensible. The disease in her eye was born with her. Her connections are numerous and very respectable. You can hardly imagine a case in which the feelings of friends and acquaintances could be more interested.

If these two cases succeed, as they promise, I shall be in danger of receiving more flattery and commendation than I can well bear.

I wish you to call on Mrs. Derby and say to her that I do not recollect whether I took the money which I deposited with her or not; if she gave it to me it is safe in my trunk at Lancaster, but if it was left by mistake, you may take it and send it to Mr. Adams by the first safe conveyance. One parcel was for Mr. Adams, and the other for Mr. Gilbert, which was about i 4 dollars.

I feel more inclined than ever to move to Boston to practice my profession. I am with sentiments of esteem your friend and servant,

Nathan Smith." 
"Worcester, 2 Ist March, I 8 I I.

\section{Dear Sir :}

I wrote you on the I 8 th inst. and believe I forgot to give you your title which you may be assured was not from the want of due respect. Since I wrote you I have performed on an eye in Sutton; the case was a singular one, the cataract was as hard as calculus; when touched with the needle it broke with an audible sound, like that of glass, which was heard by the bystanders, and a portion of it, about one third part of it, slipped through the pupil into the anterior chamber and fell below the pupil; another part of it adhered very firmly to the ${ }^{10}$. . . and returned with great violence after it was depressed, but at length the pupil was nearly or quite cleared and the light passed into the eye and the man exclaimed that he could see. The piece of cataract which passed through into the anterior chamber remains below the pupil and I do not know that it will ever be absorbed on account of the unusual hardness, and unless it should irritate the iris or cornea by resting on them, I do not know that it will do any harm, except the deformity, as it appears white through the cornea. The case was one of those which was from the birth of the person, who was about thirty years old.

Governor Lincoln and Miss Paine are both in a most hopeful and promising way. The Governor could see to count his fingers in a very . . . light, and Miss Paine this morning . . . we uncovered her eye we held a 10 The paper of the letter was torn where the words are left out. 
bowl of water before her and asked her if she could see it. She looked at it and said she could see the bowl but the water did not appear as she expected and should think there was something in it. There was a piece of sponge in the bottom of it. I shall set off for Hanover to-morrow morning covered with glory. I suppose I shall be accused of delay and wrong disposition of my time by the good people in our own vicinity, but I thought those two cases in Worcester were of such importance to me that a few days' time should not prevent my improving the opportunity to my best advantage.

Dr. G. C. Shattuck, Boston."

Nathan Smith.

"Dear Sir :

I have enclosed to you a note against Noble Orr, as you will see. I wish you to deliver the note to Captain Joshua Blake. You may leave the note with Messrs. Stanton and Spelman with whom Blake is concerned, to be delivered to Blake who is going to Havana where Orr is, and Mr. Blake tells me that he knows him and that he has no doubt but the money will be obtained on the note.

I left Worcester yesterday. All my cases were very promising then.

I am, with sentiments of esteem,

Your Friend and Servant,

Nathan Smith. 
Mr. Blake is going out soon, of course wish you to attend to the business soon.

Lancaster, March 23, I8Ir.

Dr. G. C. Shattuck, Boston."

\section{"Dear Sir:}

I have this day received your favor enclosing the money which I left with Mrs. Derby which came safely to hand, and have enclosed to you Dr. Abbot's note which you will perceive had turned into an execution and which you will find endorsed satisfied. I will also enclose to you the note against Dr. Nye and Dr. Foster as soon as I can find it.

I left Lancaster on the day I wrote you from that place and arrived at Brattleborough on Sunday morning after. We were obliged to wait there for the stage till Tuesday morning and to fill up my time I was engaged to reduce a dislocated shoulder which had been dislocated nine weeks. I succeeded in about half an hour. Afterwards on the same day a child was brought to me with cataracts in his eyes.

The child was a beautiful and very sprightly boy of . three years old. The question was whether we should operate immediately and run the risk of failing in the operation from the restiveness of the child, or defer it till the child was ten or twelve years old. Considering how much the child must lose by being blind so many years and how very troublesome it would be for the parents, I determined to attempt an operation which 
was effected in the most safe and perfect manner and I have no doubt of final success in the case. At Charlestown I amputated a finger and performed for a Hydrocele.

I arrived at home last evening, finding my family and friends all well.

I am with sentiments of esteem,

Your Friend and Servant,

Nathan Smith.

Hanover, March 28, I8II.

Dr. G. C. Shattuck, Boston."

"Dear Sir :

I have enclosed to you a note against Dr. N. Whitman of Bridgewater. The conditions were that I was not to drive him to pay, which promise must be kept, but if he could probably help me to the money I would willingly make him such a discount as would satisfy him.

I have also sent you a note against Selfridge which I wish you to present to Thos. O. Selfridge and obtain pay if possible. I have also sent a note against Dr. Abraham Menan who lives in Mendheim or Cumberland, Mass. I wish you to send the note to some person in that vicinity to be collected. For all these things and for the postage of letters, \&c. I wish you to pay yourself out of the first money that comes into your hands which is my property. 
Perhaps Dr. Perkins can make use of the notes to his advantage. If so let him have them.

\section{Nathan Smith.}

March 3I, I8II.

Dr. Shattuck, Boston.

P. S.-The money by Mr. Payne came safe to hand.

I have a case of cataract since I came home which promises success.

I have also sent you a note of Ephraim Wales. I believe you had a note against him before which he partly paid to me and had a receipt for the same and he has since paid same to D- for me. I wish you to present him both notes and let him bring in his receipts, \&c. and pay me the balance. Another note against Saml. who lived in Manchester, which perhaps his brother will pay if pains are taken to look it up." 


\section{CHAPTER EIGHTH}

The letter of April I 5, I 8 I I, brings forward a little glimpse of the family of Dr. Smith. It will be remembered that the Ryno he speaks of with such pride was his second son, Nathan Ryno, then a lad of fourteen, who was destined to become distinguished in later years, as this history will show. At the time this letter was written, Dr. Nathan Smith and his wife, Sarah Chase, were the parents of nine children, four sons and five daughters. Solon, the eldest, of whom we have heard, was sixteen years old, and the youngest then was the little baby, John Derby.

Although deeply engrossed in his practice and business interests, there never was a more devoted husband and father than Dr. Smith. His daughter-in-law, who knew him intimately, told the writer that he was the tenderest and gentlest man in his home that she ever saw.

This letter is one of the most important of the collection, for, after telling of his children, Dr. Smith gives to Dr. Shattuck, in his own handwriting, a full account of the origin of the Dartmouth Medical School.

\section{Dear Sir:}

"Hanover, April r 5, I 8 I I.

I have received your favor by Dr. Perkins and am much obligated to you for your attention to my business respecting the note against Selfridge. I think with you 
that it will be improper to urge his brother to pay it. I shall consider it lost.

You will recollect that Sylvester wrote you that Ryno had gone all amiss, and I really supposed he had been idle during my absence and intended to have inquired into his conduct in a few days after my return. It happened, however, that the school he attended was to be examined a few days after my return. I was not present at the examination, being called off on urgent business, but Professor Shurtleff ${ }^{11}$ attended and, without soliciting, told me that Ryno Smith passed the best examination on the Principles of Arithmetic he ever witnessed in any person of his age. Ryno began the study of Arithmetic in January last and was examined about the last day of March, so that we may form some judgment how he has spent his time. So much for the boy who goes all amiss.

I know not how it happened but so it is, that a certain kind of owl-like gravity in men gives them great credit for wisdom, and stupidity and aversion to play in a boy secures him the reputation of a good scholar.

Mr. Perry, who taught Ryno last winter, is now a member of my family and has the charge of the education of my children. I have great reason to be satisfied with the progress of Solon, made during my absence, and the little girls have exceeded my most sanguine hopes in their improvement.

Respecting the origin of the Medical School in this

11 Roswell Shurtleff, A.B. 1799 Dartmouth, tutor, professor, college pastor and librarian, filling at Dartmouth one or more of these positions at a time between 1800 and 1861 . 
place: I gave the first course of medical lectures in 1797 beginning in November,-was made Professor in I 798. Dr. Lyman Spalding gave a course of chemical lectures in 1801 or 2, - he can inform you the exact date, and whether he gave one or two courses. I do not know. Dr. Ramsey gave a course on Anatomy in 1808 . The State Legislature granted to me 600 dollars for chemical apparatus in 1803 and in 1809 granted 3450 dollars for a Medical Building, which is now begun and progressing and will be finished by the first of October. I obtained both grants by my petitions alone.

N. Sмітн.

Dr. G. C. Shattuck, Boston."

"Received April 20, I8 I I."

"Dear Sir:

Your favor of 16 th inst. I received yesterday. The package from London contained a diploma from the London Medical Society with several pamphlets relating to the doings of the Humane Society in London.

I perceive that the folks in London are forgetful as we are on this side of the Atlantic. I had a diploma from the same Society in the year I797, and in a letter from Dr. Lettsom he remarked on the properties of the Bloodroot, a specimen of which I sent him, that the astringent qualities of it rendered its effect in dysenteric cases doubtful. Now I never mentioned in my letter that it was astringent, neither do I think that it is so, or at least its astringent properties are but trifling and probably constitute no part of its medical 
virtue, besides, I did not mention it as a remedy in dysentery. The diseases I mentioned in my letter in which it had been useful were: acute rheumatism, bleeding from the lungs, coughs, and epileptic fits. I conclude the good old man wrote long after receiving my letter.

Respecting your application in favor of young Parkman $;^{12}-$ Dr. Perkins and myself shall be happy to recommend him to our Hanover Board of Trustees for a degree, and from my own knowledge of his perseverance in studies and the excellence of his mind, I shall consider it as a just tribute to his superior merit.

I intended to have spent this winter in Boston, but in reviewing my affairs I found them such as required my presence at home and all my exertions to bring them into a better form. I have made considerable progress in settlement of my old affairs and hope in the course of the year to see myself in better circumstances. Our business has been very good this winter and we have no reason to be dissatisfied with our income excepting that the usual delay in payments in this district gives us some trouble at present.

I shall spend a part of the summer in Boston. I am

12 Presumably George Parkman, then twenty-one years of age, Harvard A.M. 1809. Evidently a young man of great promise, for although Dartmouth did not give him a degree, he had that recognition from Aberdeen in 1813. He became one of Boston's noted physicians and gave the land upon which the Harvard Medical School was built. The Parkman Professorship of Anatomy and Surgery was established in 1847 and named in his honor, and this chair was occupied by Dr. Oliver Wendell Holmes, 1847-1882-1894 Emeritus. Dr. Parkman was murdered in the College laboratory. 
about to petition the Legislature of New Hampshire at their next session for an additional grant to cover one thousand dollars which I expended in building the Medical House over and above what the State granted for that purpose and for another thousand to begin a botanical garden. The Russian stove I have heard of and calculate when I come to Boston to procure plans for building them in my house.

Yours etc.

Nathan Smith.

Please to give my own and Mrs. Smith's best respects to Mrs. Shattuck, Mrs. Davis, and to Mr. and Mrs. Derby.

Hanover, April.

To George C. Shattuck, M.D., Boston."

It is thought best to publish all of the letters of Dr. Smith to Dr. Shattuck in full, as they give better evidence of the vast extent of his professional work than can be procured in any other way. They tell not only of his interest in the Medical School, but of his medical and surgical practice throughout New England, as he described it: "bandied about from one part of the country to the other." The last week of April of I 8 I I, he was eighty miles above Hanover with an ill patient; a few days later at Bath attending spotted fever; at Exeter, the last of May, to attend the meeting of the Legislature in the interest of the Medical School, going thence to Concord, where he operated 
successfully on Mr. Cushman for artificial joint. In September he writes from Worcester of having had six operations for cataract in various localities during two weeks, besides an operation for the same thing on Judge Lincoln; and in the same letter he expresses the intention of visiting Boston within a few days.

Under date of June 26, I 8 I 2, Dr. Smith describes his tour of three weeks, spent in again attending the meeting of the Legislature of New Hampshire, as well as in ministering to the sick, blind and halt about the Merrimack, and performing several operations among them; also of the prospect of visiting Boston again in July. Evidently after leaving Boston under pressure and hurry of business, he writes, under date of July I I, of hoping to be there in September, and that on his way home to Hanover he had extirpated a tumor in Truro and another in Charlestown, and on his arrival performed a very serious operation on the thigh of a lad for necrosis, and adds, "the cure is certain." Within a week he is to operate in Concord, and next in Walpole for an exostosis of the thigh bone.

It may be noticed that the majority of those distant visits for professional work were made during the vacation months of the Dartmouth Medical School. During the lecture terms there is not a doubt but that Dr. Smith's conscientious and earnest endeavors were given to the instruction of his classes.

"Dear Sir:

I have fallen to my old habits and am bandied about from one part of the country to the other. Last week 
I was in the upper Coos, eighty miles above Hanover and am now at Weathersfield in the service of $\mathrm{Mr}$. Jarvis, late Consul at Lisbon who has been dangerously sick but is, I think, to-day out of danger.

We have broke ground for the foundation of the Medical House and every part of the business towards the completion of the building is in happy progress.

The spotted fever is still ravaging various parts of this part of our country. I saw four persons sick of that terrible disease at Bath a few days since. Two children, who were taken the morning of the same day. I was there, died before noon. Perhaps you may have seen some of the newspaper publications from several of the medical gentlemen in this quarter, and, if so, you may remember the old proverb, viz.: 'In trouble every fool pretends to advise and if more happy thinks himself more wise.' The object of these publications seems to be principally to puff their authors and to brag of what they have done, and two of those teachers of the public have fallen out and have accused each other of telling more than was true in their own favor, and the public, I believe, are generally agreed that they are both correct in that particular.

I wish you to see Mr. and Mrs. Derby, and after remembering me to them in the most affectionate manner, inquire of them whether I am to expect a visit from them, Mr. and Mrs. and Miss Davis in June next. I shall be at Exeter on the last Wednesday in May and shall be home in about four days from that day; should like to receive them the beginning of the second week in June. 
You may inform my friends that I shall be in Boston the latter part of June.

I am with sentiments of esteem,

Your Friend and Servant, Nathan Smith.

Hanover, May 2, I8I I.

Dr. George C. Shattuck, Boston."

Dear Sir :

"Hanover, May 4, I8 I I.

I have this moment rec'd your letter by the last mail and you may rest assured that I have not for many days read a letter that gave me half so much joy. I think you have taken the wisest measures to effect the best purposes and have no doubt but you are candidate for as much happiness as falls to the lot of human nature. You must however remember that it is not always in the power of man to secure his own happiness, tho', I think yours looks as well in prospect as that of any man within my knowledge.

I wrote you last week by Mrs. S. Jarvis of Claremont but possibly you may not receive the letter so soon as this will reach you. In that letter I requested you after presenting my best respects to Mr. \& Mrs. Derby, Mrs. Davis, Miss Eliza D. \& Miss E. Williams, to inquire of them when I might expect to see them at my house. I shall be at Exeter on the last Wednesday in May next \& shall return the week after, so that it would be convenient for me to receive them about the 2nd week in June. I have rec'd a letter from Dr. 
Whitman informing me that Mr. Peabody had called on him to pay the note \&c. I thought I expressed to you in the letter inclosing the notes that Whitman was not to be called on for the note unless it was convenient for him to pay, but it may be I neglected it. As Whitman cannot pay till fall I wish you would speak to $\mathrm{Mr}$. Peabody to give you the note $\&$ wish you to keep it till Dr. W. can pay it \&c. I am with sentiments of esteem, Yours in great haste,

Dr. G. C. Shattuck, Boston."

Nathan Smith.

\section{"Dear Sir :}

I should like to know to a day when I may expect Mr. Derby and company at my house. You will bear in mind that I must be at Exeter on the last Wednesday of this month which will be next week, and if $\mathrm{Mr}$. Derby should not be here till the Monday or Saturday after our elections, which will be on the first Wednesday in June, I should probably stay and see our elections at Concord; but if $\mathrm{Mr}$. Derby has made his arrangements otherwise you will not communicate that wish of mine to him as it is a matter of great indifference to me whether I am at elections or not.

I have had two successful operations for cataract,both old men, one 72 and the other 84, - the last week. I have no doubt of the success of both cases. The man aged 72, was one of old Bob Rogers' Rangers and has served through the whole of the Revolutionary War. All I expect in either case is the pleasure of doing good, 
as they are both extremely poor. Mr. Cushman of Concord, who suffered the operation for an artificial joint, has recovered so $f a r$ as to walk with crutches. The thigh bone has united firmly; it is a little shortened. This patient, from want of proper attention, has suffered a confinement at least twice as long as was necessary and the limb is less perfect than it might have been in a similar case so situated that I could attend it. I am certain I could cure it in half the time and have the limb the full length. I consider the experiment a sufficient warranty for such observation.

I am with sentiments of esteem and sincere friendship,

Your humble Servant,

Nathan Smith.

Hanover, Sunday, May I9, I8 I I.

Dr. G. C. Shattuck."

\section{"Dear Sir:}

I left home a fortnight since $\&$ since that time have had six operations of couching besides an operation on Judge Lincoln which I performed yesterday; the cataract has risen but the eye is not injured \& I shall at length make his sight perfect. I regret very much that I was not able to be at Boston on the day you mentioned in your last letter to me, but my business seemed to require my delay \& I assure you that you \& Miss Davis have my warmest wishes $\&$ most fervent prayers for your mutual happiness. 
I shall probably be in Boston on the day after tomorrow. I am with sentiments of esteem,

\section{Yours sincerely}

Nathan Smith.

Worcester, September 25, I8 I I.

Dr. G. C. Shattuck."

"Hanover, December 20.

Dear Sir :

Immediately on receiving yours by Dr. Twitchel I wrote to Bradley \& Gardner \& by the last mail they write that Dr. Waterhouse has obtained the appointment which I was soliciting for you. . . . I have closed my course of public instructions for the present year perhaps with as much credit as I have done heretofore. We had a very good course on Anatomy, much better than at any former time. We were very fortunate in obtaining subjects and have dissected three who were all pretty good; the one brought by $\mathrm{T}$. was excellent.

I have lately added 52 volumes to my. library of historical works, viz: Mavors' General History, 26 vols., Mavors' Voyages, I 9 vols., and Hume's England, 8 vols. As my time is so taken up that I cannot read such lengthy works, have set two pupils to reading in course and have requested them to fix a kind of index to everything relating to medicine or medical men to be found in the several works, so that I hope to reap some advantage from the books tho' they are not medical.

In your last, you mentioned a gentleman who is going 
to England and who will purchase any books I wish for. I do not know whether he is a bookseller or whether he must have the money to purchase with before he goes; if he is a dealer in books and will purchase books which are wanted and will wait for his money till the books are delivered at Boston, should be glad to purchase to a considerable amount, but the dearth of money ${ }^{13}$ here is so great that I cannot immediately send enough to make it any object, not having as yet made any collections the present year. I will, however, make out a list of books which I should be glad to purchase and for which I would pay the money as soon as the books could be procured, and perhaps the man you mention or some importer of books will be willing to order out the books.

Bell's Anatomical Tables and Dissections.

Sayer Walker's Observations on the Constitutions of Women and Diseases to Which They are Liable.

Pemberton's On Diseases of the Abdominal Viscera.

Stone On Diseases of the Stomach.

Everard Homes' Observations on Cancer.

I wish you to send me one canister of the best battle gunpowder,

\section{Yours sincerely, \&c.}

\section{N. Sмiтн.}

To Dr. George C. Shattuck, Boston.

Wish you to put the formula in the mail if you have no opportunity to send it immediately (?)."

13 Perhaps due to the War of 1812 . 


\section{"Dear Sir:}

I have only a moment to write you and can only inform you that we are all well at present. I have just returned from a tour of about three weeks spent in attending our Legislature and attending on the sick, blind and halt on and about the Merrimack. Our Legislature did not see fit to allow me the I,2 I 7 dollars I expended in building the medical school at Hanover over and above the grant made by the Legislature for that purpose, but I have no doubt but they will at their next meeting.

I have among several operations performed on my tour, worked twice with success and have a patient now waiting for the operation to be performed this morning.

I shall probably be in Boston next month; till then please remain assured of my very great esteem and sincere friendship. Also please to give my respects to Mrs. Shattuck, Mrs. Davis and Mr. and Mrs. Derby.

$$
\text { Yours, \&c. }
$$

Nathan Smith.

Hanover, June 26, I 8 I 2.

To George C. Shattuck, M. D., Boston."

Dear Sir :

“Hanover, July I I, I 8 I 2.

. . I wish you to tell Mr. Maynard that I intended to have seen him before I left town \& have spoken with him on the subject of what I owed him, but the hurry of business prevented it. You may 
inform him that I shall be at Boston early in September next \& will then settle with him. On my way home I extirpated a tumor in Truro, another in Charlestown, \& since I arrived I have removed a large sequestra from the thigh bone of a lad. The dead bone is about four inches in length of the whole femur. I divided the flesh, introduced a trephine, sawed off the dead portion of bone in the middle, $\&$ drew out first one end $\&$ then the other. The cure is certain. I am going this week to perform an operation in N. Concord, where an artificial joint has been made in the thigh bone, \& next week in Walpole for an exostosis on the thigh bone.

Dr. G. C. Shattuck."

Nathan Smith. 


\section{CHAPTER NINTH}

The accompanying photograph will give some idea of the form of the old medical building for which Dr. Smith obtained the grant and gave his land, anatomical museum, etc., and which was the first independent home of the Dartmouth Medical School. It was built of brick and was probably completed in the autumn of I 8 II. In the two-story centre are two good lecture halls and in the two three-story wings are smaller rooms for library, laboratory, museums, etc. The lighting of the lecture hall on the first floor, by large windows on opposite sides of the room, and the acoustic properties are exceedingly good. The seats for students are well arranged; they are placed in long rows slightly elevated one above another all the way up in front of the lecturer, and on the wall behind his position is hung a large blackboard.

The very primitive arrangements of the hall consist of a trap door beneath where the lecturer stands, which opens into an underground place, where a hundred years ago subjects were kept and lifted up for anatomical study. Running almost all the way across the room in front of the lecturer is a broad counterlike table somewhat rounded at the corners, a part of which must have served for anatomical demonstrations; about one third of it at the other end, being detached and on small wheels fitted to a little track, could be rolled through a side door into an adjoining 
room where patients prepared for surgical operations were placed upon the table and rolled back into the lecture hall ready for the surgeon.

In those old days no aseptic treatment was practiced, nor had antiseptics been discovered, for the world was in blissful ignorance of the presence of lurking germs, now recognized as arch enemies to the health of the human race. But, although germs were undiscovered, pain was fully understood and believed in, and-sad to say-no anesthetics were known by which to deaden the sufferings of patients, or the sympathies of the tender-hearted surgeon.

An early pupil of Dr. Smith at New Haven, Dr. Abraham T. Lowe of Boston, who, when a student, accompanied him to a distant town to assist him in performing a capital operation, described to Dr. Hubbard, as follows, Dr. Smith's deep sympathy for the patient on this occasion:

"It was a chilly morning, as we sat by the fire, and the doctor looked at the patient at the farther end of the room. The lad was emaciated and trembling. Dr. Smith was visibly affected, his eyes dropped tears and his hand trembled as he whispered to me: 'I shall not do what they expect. It is a cruel business, and I will perform a less severe operation, in the hope it may have the same effect.' On examination it became apparent that the severer operation (amputation of the thigh) could not be avoided. Before we returned to the room, he said to the attending physician, 'Hall, you know all about this boy's sufferings; at the moment we begin, bend over and across the bed to hide us from 


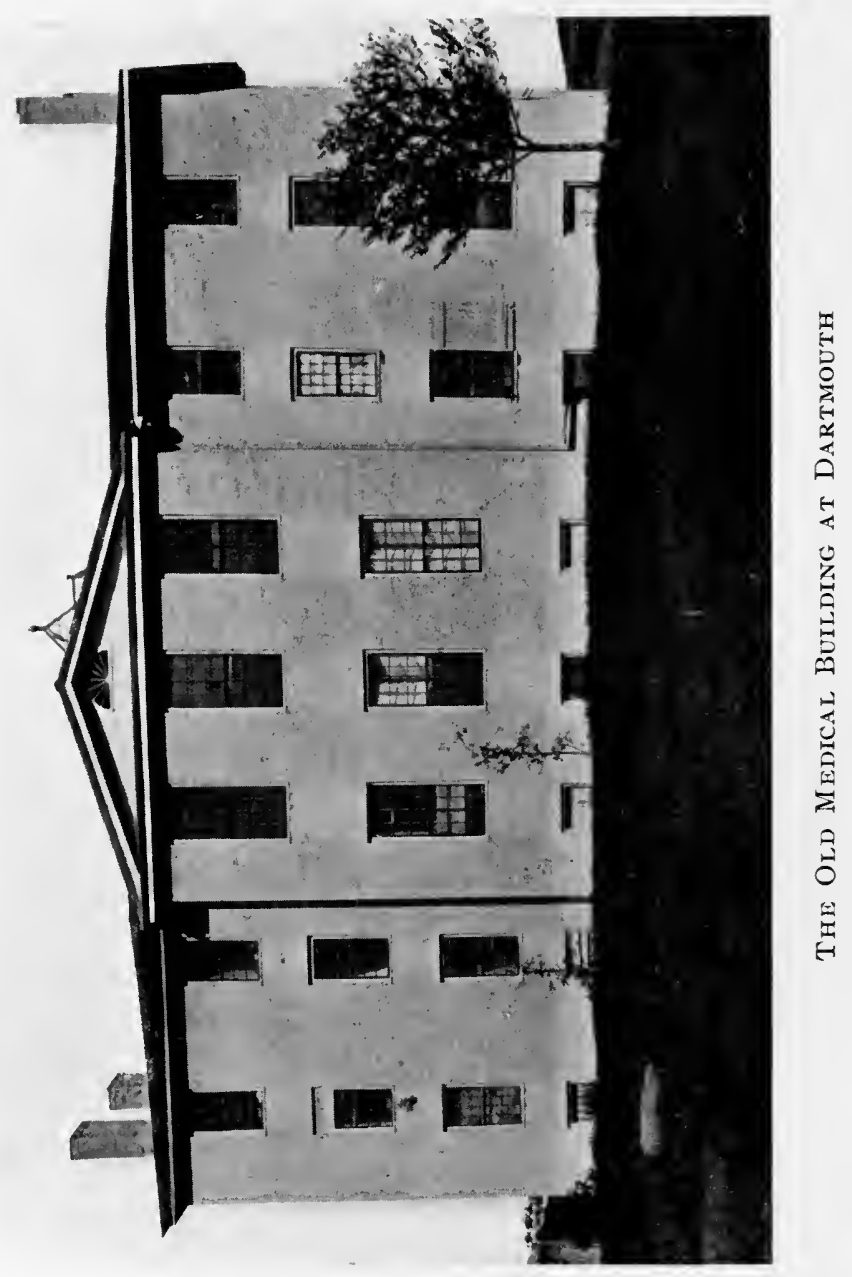



his sight, and do your best to comfort him,' the tears still falling from his eyes. At once he became calm, the tremor left him, and in less time than while I write this period, the operation was completed, and the patient recovered."

Dr. Lowe adds: "Dr. Smith was a great and good man. He never seemed to toil for professional fame, but to do good to his fellow men." The old hall of the Medical Building at Dartmouth was the scene of many minor operations, and when sufferers were brought from distant places to be relieved from complaints and injuries, after the wheeling back into the little dressing room of the operating hall, they were often subjected to the further ordeal of being transported to their homes on mattresses in wagons. But, in spite of the want of later day science, the majority of patients recovered and lived long lives.

The hall of the old Medical Building is light and airy, and some of the lectures are still given there. Dr. Gilman D. Frost, the present Professor of Anatomy, who kindly showed the writer through the building, values highly its association with the man who first filled the chair, or-as Dr. Oliver Wendell Holmes expresses it-who filled a "Settee of Professorships." Very recently Dr. Abraham Flexner has added his tribute, speaking of him as the man who "was its entire faculty, and a very able faculty at that."

While still retaining the use of what is so good of the old building, Dartmouth now possesses excellent modern conveniences for its medical school. On one side of the structure of $\mathrm{I} 8 \mathrm{II}$, there is an up-to-date 
building for dissecting and anatomical study, and on the other side of it has been erected the splendid "Nathan Smith Laboratory," for chemical and pathological research. Not far away from this group of buildings is the beautiful "Mary Hitchcock Hospital," which, although not very large, is fitted up with every comfort for the sick, and also with operating rooms, whose spotless and lovely white marble walls and tiled floors are in every way sanitary. Indeed, all the arrangements of the hospital show it to be as thoroughly equipped for surgery as any hospital in the world.

This venerable Medical School of Dartmouth,-the fourth institution of the kind in the United States,has created a record worthy of all honor during the century and more of its existence; from its lecture halls have gone forth not only well-taught physicians to do work in distant country neighborhoods, but numbered among its alumni are to be found the names of some of the most useful and distinguished physicians and teachers throughout the country; men who have held chairs in other colleges and, in their turn, been the instructors of scientists and discoverers who have built upon their foundation.

One of the most carefully kept of Dr. Smith's old ledgers contains only the notes of his lectures on chemistry and, as he was never a regularly appointed professor of chemistry after leaving Hanover, it is reasonable to suppose that these lectures were delivered in the Dartmouth Medical School before the year I 813, when he left for New Haven. All of the lectures show 
a wonderful amount of study, and also of original thought, and one of them ends with the following remarkable prophecy.

\section{Extract from a Lecture on Chemistry}

by Nathan Smith, delivered at Hanover-probably before 1813 .

"Respecting what the effect of chemistry on medicine may be hereafter is uncertain, but it is conjectured that it will be able to discover the nature and composition of inanimate animal matter, that it will precisely discover and determine the chemical effects which take place in living animals, that it will also discover what takes place in organic injuries, and in what diseases consist, that it will discover the means of preventing such injury at its commencement and of remedying several of them when produced, and that it will simplify materia medica. That it will effect all this is by some fondly hoped, in the first place: by pursuing with ardor the modern analysis,-so different from the ancient; by making physiological experiments such as those of Spallanzani on digestion, of Lavoisier on respiration and Vauquelin on excrements; by operating, in an Hospital consecrated to experiments of that kind, on the liquids and organs altered by disease before and after death; by experiments tried with prudence on diseases after the notions formed from preceding data ; by causing only well known remedies to be prescribed; by discarding all inert substances; by forbidding such as are poisonous; by reducing the number of 
medicines to such as possess real activity, and lastly, by rendering the formulæ of medicine more exact."

In the hundred years which have passed since these words were uttered, what of all that Dr. Smith foretold has not been accomplished by chemistry? How fitting and poetically appropriate that, almost upon the very spot where his words were spoken, a beautiful building has recently been erected, bearing in his honor the name of "The Nathan Smith Laboratory," where, as he fondly hoped, in a "Hospital consecrated to experiments of that kind," scientists of to-day are pursuing with ardor the modern analysis, and, by chemical and pathological research, carrying on some of the work which is giving to the world discoveries and benefits far exceeding his most loving and most ambitious dreams.

In the year I 8 I 2 , it was decided to establish a medical department at Yale College and, knowing of Dr. Smith's rare ability as an organizer and teacher, and of his great skill in the practice of medicine and surgery, the trustees selected him as the man best fitted to aid in the enterprise and invited him to become Professor of the Theory and Practice of Physic, Surgery and Obstetrics in the new institution.

It is easy to gather from one or two of the foregoing letters-especially the one of May I4, I8rothat Dr. Smith had found thickening clouds of diffculty closing in around his work at Hanover.

Although his classes in the Medical Department of Dartmouth were steadily increasing in numbers and were filled by intelligent young men attracted to the 


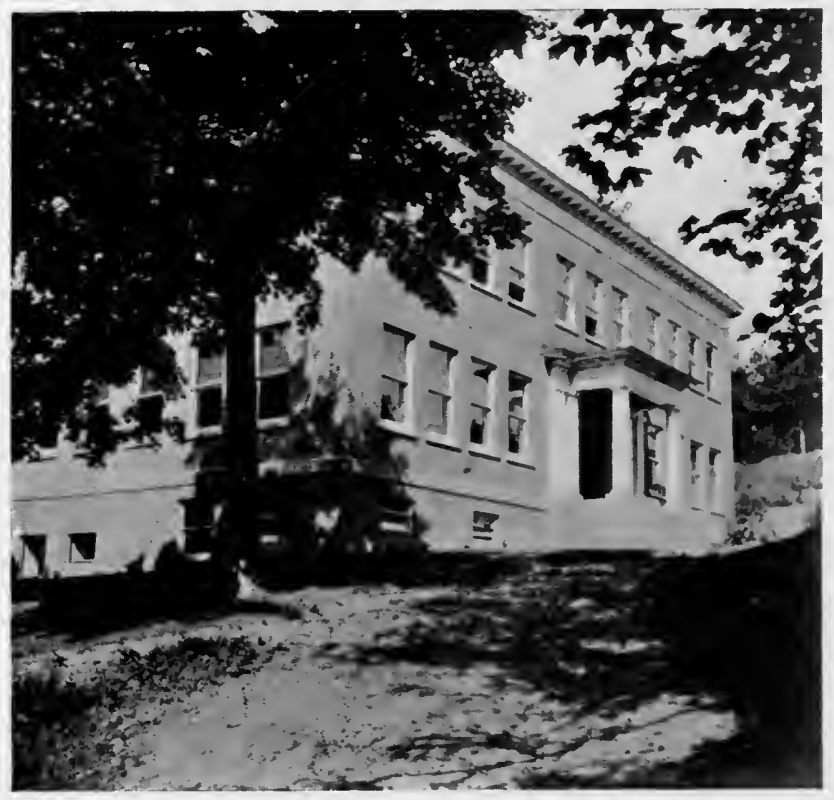

The Nathax Smith Laboratory at Dartmouth 

school by his rare ability as a teacher, he began to feel as though he were held in the strong grip of circumstances impossible any longer to contend against. The poverty of the state and political jealousies which separated men into parties were already threatening the crisis which a little later came to the Dartmouth School and which brought forth the noted and pathetic appeal from Daniel Webster before the Federal Supreme Court, when he is said to have shed tears, while pleading, in one of his eloquent speeches, for the life of his Alma Mater.

To question Dr. Smith's patience or unselfish devotion to the child of his fostering care, would be an injustice that no one could be guilty of after reading of all he had endured to bring it into existence; but, perhaps, in his wisdom and keen foresight, he may have seen that his future usefulness there was being made impossible, and that some new element was needed to complete the work.

In what way he was influenced to leave Dartmouth no one can tell. But it is evident that the Higher Power which orders the destinies of men had work in other fields awaiting the services of the master hand which had accomplished so much already.

President Wheelock and the trustees of Dartmouth College regretted exceedingly the parting with Dr. Smith and were as slow in accepting his resignation as they had been in accepting his proposition to establish the Medical School, for their action was delayed until I $8 \mathrm{r} 4$.

Two years later, in 1816 , Dr. Smith returned by 
invitation to give another course of lectures which was attended by sixty-six medical and forty-four college students. ${ }^{14} \mathrm{He}$ was at this time reëlected to a professorship, but declined to accept and the trustees were obliged to consider his action in leaving Dartmouth as final.

The tremendous start given to the school by Nathan Smith's unprecedented skill and energy carried it along through many years until its reputation was spread far and wide; indeed, Dr. Hubbard asserts that "comparing the two schools [the Medical Schools of Harvard and Dartmouth] from 1798 to 1828 , both inclusive, Harvard graduated two hundred and thirty students of medicine, and Dartmouth three hundred and forty."

No wonder that Dr. Hubbard is impelled to add: "If this were the climax of Dr. Smith's life and he had rested from his labors, and this school was his only monument, we might justly inscribe upon it [the Dartmouth motto], "Gaudet tentamine Virtus."

Dr. Smith had already arrived at the age of fiftyone years, a time of life when, after achieving a great work, men usually crave the quiet of home and rest from some of their arduous labors; but the zeal of this man was untiring, he weighed the ponderous question before him carefully and decided that the new field where ground had to be broken needed him more than the one which was then in a flourishing state of cultivation. In his acceptance of this professorship in the Yale Medical School selfish considerations had no

14 Hubbard, p. 20. 
weight. To leave family and friends and the school which he had struggled for fifteen years to establish, must have cost the good doctor many a heartache, but once recognizing a call to be that of duty, there was no hesitation in his obedience.

Dr. Smith owned a little farm at Hanover where he could leave his wife and younger children in comfort until he could make a home for them at New Haven, and plans were made to take up the new work in Yale College at an early day. But, as the following letters from him to Dr. Silliman will show, Dr. Smith was detained in Hanover by the spread of a most disastrous epidemic, which extended even to members of his own family.

In his letters to Dr. Silliman, Dr. Smith gives no name to the disease, but from his "Essay on Typhus Fever," on page 75 of "Medical and Surgical Memoirs," we gather that this epidemic was what was then called typhus fever (now typhoid), for he states: "In the autumn of I8r2, Professor Perkins, now of New York, and myself attended between fifty and sixty cases of Typhus in the vicinity of Dartmouth College, and many of them were students of the Institution; of the whole number which came under our care, only one was bled, and that on account of a sense of fullness in the head of which he complained, . . . he eventually recovered," and, the doctor adds, "Of all our patients we lost but one."

The remarkable success of Dr. Smith in saving the lives of so many patients ill with this dread disease, was due to his entirely original and independent treat- 
ment, which he had devised and practiced as early as the year 1798 at Cornish. This treatment is described in the article on typhus fever, referred to above.

Of the letters relative to Dr. Smith's call to New Haven one has been preserved, addressed to Dr. Mason Fitch Cogswell, of Hartford, a noted physician and the founder of the first asylum in the country for deaf-mutes. Dr. Cogswell had been asked to take the chair subsequently offered to Dr. Smith, but felt his work in Hartford of too great importance to leave. This letter, though undated, evidently was written at about this time and shows the humble spirit of the truly great man, ready to acknowledge himself at fault and to endeavor to undo such harm as he may have been instrumental in causing. This was a period in which the faith of many thinking men was severely shaken as the result of books published about that time, notably Paine's "Age of Reason," and perhaps Dr. Smith may have been for a time one of those so influenced.

The early part of the letter has to do exclusively with surgical cases. The last part, referring to Dr. Smith's call to New Haven and the considerations set forth by the president of the college, is as follows:

"Respecting Dr. Dwight's former objections to me, I freely acknowledge that they were well founded and such as a wise and good man would always consider as all important. My earnest prayer now is to live to undo all the evil I have done by expressing my doubts as to the truth of Divine Revelation, and to render 
to Society all the good my talents and powers will permit me to do.

I am with sentiments of esteem

Your friend and servant,

Nathan Smith."

"Hanover, March 3 I, I8I3.

Prof. Silliman, New Haven, Ct.

Dear Sir :

Your favor of the I 9 th has been received. According to my promise to Dr. Cogswell I intended to have visited you at New Haven last January, but before I was ready to set off on my journey, we were visited by a very fatal epidemic and instances of sickness and mortality became so frequent that $\mathrm{I}$ was afraid to leave my family in such perilous times; and my fears were not groundless,- four of my children have lately been affected by the prevailing epidemic, but by the Divine Goodness have nearly recovered. I believe this country has never before been visited by sickness which has carried off so great a number of adult persons in so short a time. In some towns of this vicinity which contain perhaps from IOOO to I 500 inhabitants they have buried over fifty persons since the first of last January. The disease has not yet much abated either in its violence or frequency of attack. We hear of new cases every day, and almost every day brings me an account of the death of some friend or acquaintance. 
How long this dreadful calamity will be suffered to afflict us, none can tell; but we hope and pray that when the winter is over the disease will disappear.

The winter here has been long and severe. The snow is deep and the three last days have been the first springlike days we have had.

Respecting your former letter, Dr. Cogswell wrote me that he had it and declined sending it as he feared it might pass me on the road. I wrote him to keep it safe till my arrival, so that I have not seen it. Dr. Cogswell however mentioned in his letter some circumstances alluded to in yours, particularly respecting the Anatomical Museum and Library. I wrote him on that subject, that I would furnish something towards a museum and that I had between five and six hundred vols. of books, chiefly medical, which should contribute to build up the intended Institution at New Haven.

Respecting my visit to Court,-that,death excepted, you may depend on seeing me at $\mathrm{New}$ Haven before your General Court convenes at Hartford next May. I am, dear Sir, with high consideration, Your obedient Servant

Nathan Smith."

"Hanover, September 2, I 8r3.

Prof. Silliman, New Haven, Ct.

Dear Sir :

Your favour of the 28th August, was handed [me] yesterday. On my arrival at home from Boston, I found Mrs. Smith convalescent, for which I have 
great reason to render thanks to Divine Providence; she still continues to convalesce, so that I think I shall be able to leave home for New Haven soon.

Respecting the terms and regulations you have agreed on for the government of the Medical Institution, I have no fear on that subject, and doubt not but they be well adapted to the purpose for which they were made.

I think with you that it will contribute much to the prosperity of the establishment to have commons in the Medical College, as it will probably reduce the price of board, which I find is an object with many who are wishing to attend there. If this arrangement is carried into effect, the young gentlemen can certainly go through their study term at New Haven, cheaper than at Hanover; the length of time taken up in our course of lectures, ${ }^{15}$ being greater than in other institutions in New England, will be in favour of the students in a pecuniary point of view, for, while they are living at

${ }^{15} \mathrm{Dr}$. Smith had evidently already identified his interests with the institution at New Haven. It is not at first clear as to whether he means Dartmouth or Yale in speaking of "our course of lectures," but we learn through Dr. Welch, that "at the beginning, the course of medical lectures here [at Yale] extended through six months, a longer period than obtained at the time in any other medical school in this country." $\mathrm{He}$ adds in a note: "The length of the annual course was afterwards shortened to five months, then to four months (1824). In 1832 it was from the second week in November to the last week in February. It is now thirty-four weeks, exclusive of vacations." It will be more readily understood, if the length of the term was only four or five months, how it was possible for Dr. Smith to give courses at Brunswick and Burlington without interfering with his teaching at New Haven. 
as little expense as they do in the country, they pay nothing during the lectures for private tuition.

I think you have done well to prohibit the undergraduates from attending any lectures but yours (Chemistry). I have felt the embarrassment of lecturing on Anatomy and Surgery before young men who are not designed for the profession.

When Dr. Cogswell wrote to me on the subject, my answer was, that if I had an appointment in the institution, I would take any part on me that in the opinion of those concerned would contribute most to the good of the establishment. Therefore if it is thought best I will lecture as you propose. My son who entered the College at Yale some time since, left home before I arrived from Boston, expecting to meet me at Wethersfield to make arrangements for him respecting room at College and to give bond for the payment of tuition, board \&c. If anything should be necessary before I come to New Haven, I will thank you to take so much concern for him as to do what may be wanting and I will see that everything is done on my part as soon as I arrive. With sentiments of esteem, I remain, dear Sir, Your Friend and Servant,

NATHAN SMith."

(These two letters to Professor Silliman are in possession of Dr. Saml. Theobald, the great-grandson of Dr. Nathan Smith.)

In the autumn of 1813 , about a month after the writing of the second letter to Professor Silliman, Dr. 
Smith left Dartmouth for New Haven. His two sons, David Solon and Nathan Ryno, were to be with him as students at Yale College. His good friend, President Wheelock, and the trustees of Dartmouth were most reluctant to part with him. 


\section{CHAPTER TENTH}

On his arrival at New Haven, Dr. Smith was received with great kindness and cordiality. Ex-President Woolsey, of Yale College, relates that "when Dr. Smith came to lecture at Yale, in 1813 , he came directly to my father's house, and remained there all winter. $\mathrm{He}$ was the most delightful, unselfish and kind-hearted man I ever knew, and we children all loved him. He was confined to the house for a month by an injury to his leg, and it was a great treat for us to be in his room, and difficult to keep us out."

Dr. Smith wrote an interesting letter to one of his warm friends at Hanover, Mr. Mills Olcott, dated December, $18 \mathrm{r} 3$, in which he described his accident as follows: "Immediately on arriving into New Haven, I fell into such a run of business that, it being very dark one evening, I ran my leg against a plank with such violence it gave a pretty severe contusion. Fever followed, but Mr. Woolsey had received me into his house supplying all my wants both in sickness and health."

The same letter describes one of his first professional cases, - a very pretty young lady with white swelling of the knee. She informed Dr. Smith that she had had it set five times, - twice by women and three times by male bone-setters, - but, instead of getting better, it grew steadily worse every time. Dr. Smith adds: "If I should remain I must have a severe 
conflict with this tribe of bone-setters, for I never could when young and pliable get on with them, and now, grown old and stiff, I feel less inclined than ever to yield the least approbation to this kind of gentry."

As soon as Dr. Smith recovered from the injury caused by his accident, he lost no time in taking up his duties as Professor of the Theory and Practice of Physic, Surgery and Obstetrics in Yale College. There he was to have as associates: Aneas Munson, Professor of Materia Medica and Botany; Eli Ives, Adjunct Professor of Materia Medica and Botany; Benjamin Silliman, Professor of Chemistry, Mineralogy and Geology; and Jonathan Knight, Professor of Anatomy and Physiology.

Students came in numbers to benefit by the instruction of these eminent teachers, and the medical department steadily grew with the college in reputation and importance.

In addition to his work as instructor in medicine, Dr. Smith rapidly acquired a large practice, not confined to the city of New Haven, for his calls were to every county and almost every town in the state. The sick and unfortunate also came to him from a distance to get his ever ready help and advice.

In the ledger which Dr. Smith kept at New Haven, in 1813 , and 1814 , are recorded the daily visits to patients, and his charges for professional services. A photograph of one of these pages will show names familiar to many even now, for the descendants of some of these good people still live in and around New Haven. In addition to the records photographed, we 
find Roger Allen, of Woodbridge, appearing as first patient in November, I8I3. Then here and there throughout the book, there are such names as Hotchkiss, Atwater, Hoadley, Dummer, James Hillhouse, Judge Painter, Mrs. Shattuck, President Dwight, George Munson, Professor Silliman, Miss Woolsey, Jonathan Edwards Porter, another Nathan Smith, etc. Many out of town visits are recorded, and one of the last pages of the ledger is taken up with a list of visits to a lady who seems to have been a pensioner of the city, for all the charges for the visits are made to the town of New Haven.

One feature of this interesting old book is the low price charged for medical attention. For an ordinary visit with prescription the price was only fifty cents, and even when surgery was done the charge seldom reached five dollars.

Probably for economy of space and time, Dr. Smith usually made his ledgers serve for recording the heads of his lectures as well as for the keeping of his accounts. This ledger of 18 I 3 and I 814 contains a careful outline of his introductory lecture and, as it was almost certainly the first lecture ever delivered in the Yale Medical School, it may be interesting to find it introduced in the Appendix to this volume. 


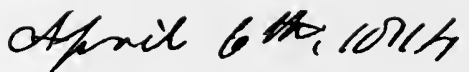

Nevid wt, the witlow

Ahul benifen, Don to vifit $x$ hns

$4^{8}$.

form Inites geto.

wifity adun: - l's

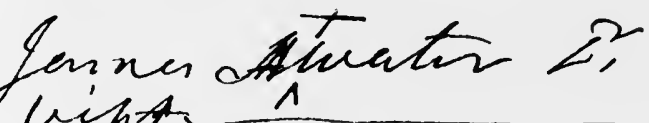

To wipar

56

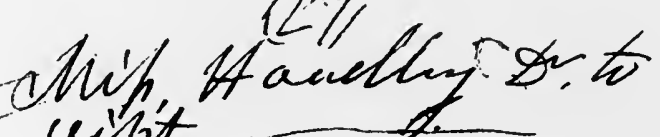

uifit ho

Resish Dinzey gits

sulge patomix y

らを

$\Delta$

to cespex $x$. - .

48

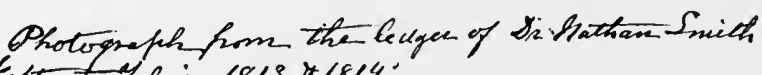
tepteat Jale in 1818 . $\forall 1814$. 



\section{CHAPTER ELEVENTH}

In order to show Dr. Smith's manner of teaching and delivering his lectures, the following extract is borrowed from Appendix E of Dr. Oliver Hubbard's admirable Historical Discourse. The lectures here described by Mr. Nesmith were probably heard by him at Dartmouth when Dr. Smith returned there for his special course in 1816 , and the introductory lecture must have been repeated by Dr. Smith from memory, as it is no doubt the one prepared in 18 I 3 for his first address at Yale College.

The Hon. George W. Nesmith (Dartmouth, I 820 ) writes: "Franklin, N. H., December 27, I879.-It was my good fortune, in I 8 I 6 , to hear him [Dr. Smith] deliver three lectures. The first was his introductory lecture, addressed to the Medical class. In this lecture he gave the history and progress of Medical Science from the days of Hippocrates down to his own time; sketching briefly the many improvements of modern days, and comparing them with the darkness and superstitious practices of ancient times; illustrating his various positions by appropriate anecdotes; closing his lecture by sensible advice to the students in reference to their conduct, their habits of study, inculcating industry, close and earnest investigation, and the acquisition of all that knowledge best calculated to make them good citizens and useful in their profession. This lecture was extempore entirely-without notes-delivered in 
plain, familiar language, without any apparent attempt at display, still demanding and receiving the strict attention of his hearers. It is now more than sixtythree years since I heard that lecture and much of what he then said is still impressed upon my memory.

"The next lecture I heard was about one month later, and was specially devoted to 'discussion upon the effects of wounds or injuries upon the head and brain.'

"This subject gave the Professor opportunity to relate to his class many and diverse cases that had occurred in his long and extensive practice. He made this lecture interesting, having a skeleton head before him, enabling him to illustrate this class of injuries to this delicate part of the human frame. The Professor allowed the students the free use of interrogatories. Whereupon a certain student, not the sharpest, intellectually, of the number, inquired 'if it would not be possible to transfer living sentient brains from one head to another's?' Professor Smith answered 'that he was not aware that a wise Providence had yet pointed out any successful mode of effecting this object; but he thought if the gentleman, who puts the question, could make a discovery of this nature, it might prove of great advantage to himself and many others in this world.' He asked no more questions that day.

"The third lecture was upon 'the diseases incident to the New England climate and their treatment.' Here Professor Smith was much at home in a learned discussion upon fevers. It appeared he had written and sent out to the public something upon this subject. My recollection is he discussed the character and symptoms 
and treatment of the Spotted Fever, which had prevailed extensively through many parts of New England. I sympathized with his remarks on this subject, and could attest to their truthfulness, because it had visited our town (Antrim?) in I8I2.

"He merited all the encomiums conferred upon him by you and more. Many of the good works that he did will never be recorded. The Institutions he aided or established will be living monuments consecrated to his memory, we trust, forever."

One beautiful trait in the character of this great man was his tenderness and strong affection for his friends and his family. All of the histories of Dr. Smith demonstrate that in his busy life he could not have had many leisure moments, and yet no rush of business could ever crowd out from his loving heart the constant thought of his home and family, so that the many necessary separations from them were among his severest trials, as the following letter to his wife will show.

"To Mrs. Sally H. Smith, Hanover, N. H.

My Dearly and Well-beloved:

I fear that my absence has been severely felt by you and the children. For my own part I have had a dreary winter of it; you may rest assured that I will never leave you and the dear children so long a time during my lifetime. I think I shall be able to get home by the middle of April. I will thank you to tell Plumley that I wish him to engage somebody to do the ploughing and sowing in the Spring, as it may be necessary to 
have it begun before I can reach home. Do kiss all the children for me and tell them that papa will come home and never leave them again.

Solon and Ryno are both very well and doing very well in their studies. Ryno is one of the first in his class and Solon has improved very much.

We have lately had some difficulty in the School between the cooks and the scholars. A cook abused one of the scholars in the kitchen and the scholars put the cook under the pump and pumped him, as it is called. I think, however, it will be settled without much difficulty. Solon was one who helped to pump the cook, but so many assisted in the thing that the blame will be light on the individuals.

Miss Painter, who was at Hanover two summers ago for her health, is here now under my care. I have obtained a good deal of business since I came here for which I shall receive my pay in the Spring. The people in New Haven expect to see you here in the Spring, but it is not certain that I shall ever remove to this place. I am with the fondest affection yours forever,

Nathan Smith.

New Haven, March 4, I814."

The school began its work in October, 1813 , with a class of over thirty students, in the building at the head of College Street, which had been erected for a hotel by James Hillhouse. This was readily adapted to its new uses and, after a short lease, purchased by the Medical Institution, together with a considerable tract of land adjoining, designed for use as a botanical 


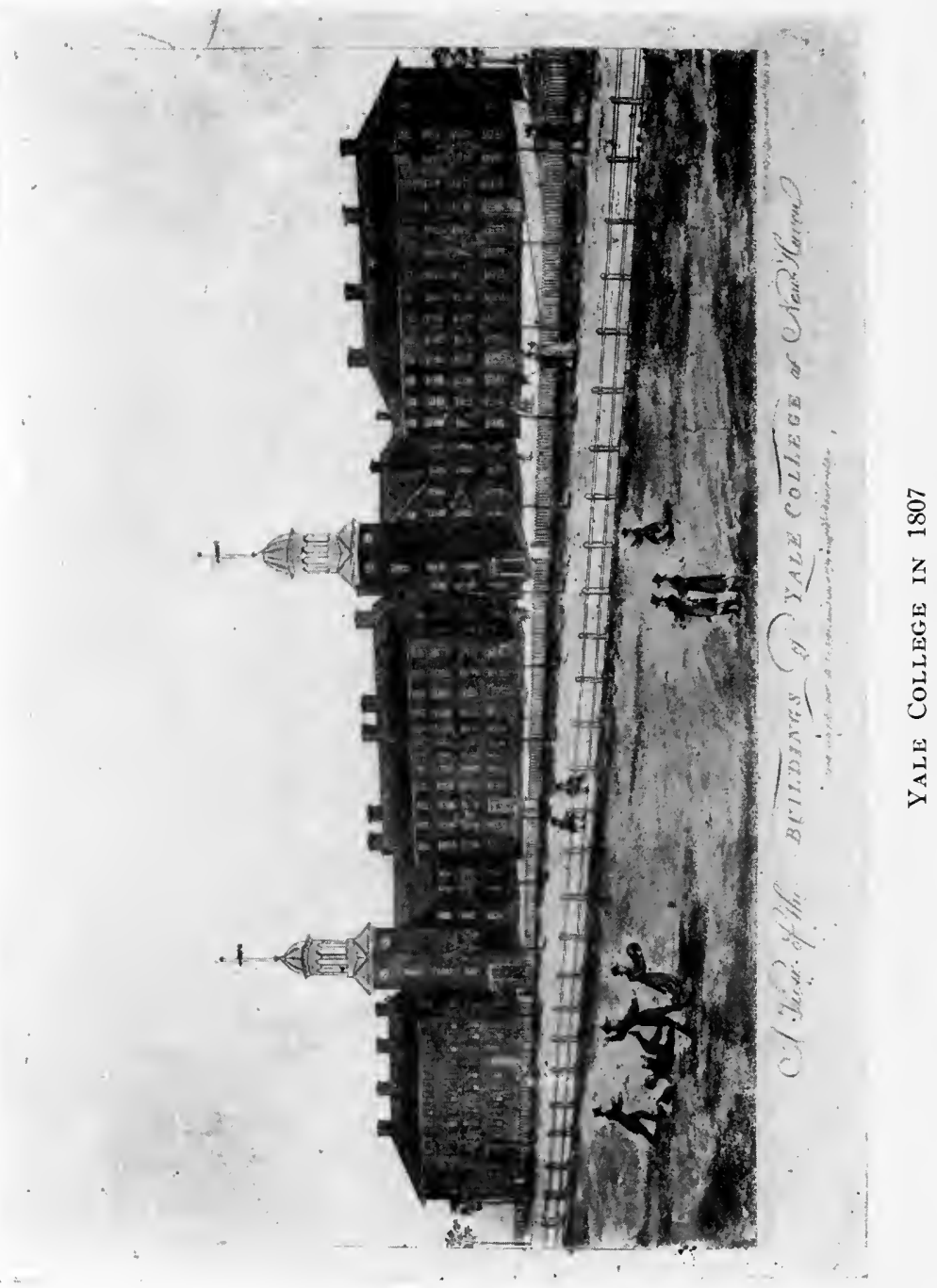



garden. The money necessary for this purchase was obtained through the personal application of Dr. Smith to the Legislature of the State of Connecticut, which responded with the generous sum of $\$ 20,000$, which proved sufficient to secure not only the building and grounds, but to furnish the beginning of a library and of an anatomical museum.

The plan for a botanical garden must have been particularly pleasing to Dr. Smith.

In his letter of October 4, I 809, he rejoiced in the opportunity offered him to profit by a garden productive of healing herbs in Salem, and in April, I 8 I I, he writes of his intention to petition the Legislature of New Hampshire for a thousand dollars with which to begin a botanical garden at Dartmouth.

"The garden for the Yale Medical School was established on grounds adjacent to the building on Grove Street, by the exertions of Professor Eli Ives and at his own expense. A hothouse was built and a variety of native and foreign plants, shrubs and trees, mostly of a medicinal nature, were planted. Dr. M. C. Leavenworth, a graduate of the Medical Department in 18 I 7 , who was a good botanist, was engaged to make a collection of indigenous plants for the garden, and at one time there was a good collection of such plants. The time and expense involved, however, proved to be burdensome, and the garden, after a protracted struggle for life, perished from neglect." -Welch, note 26.

" 'Commons' were instituted in the basement of the building, and above were sleeping and study rooms for 
the students. The close connection with the college is evidenced by the attempt to introduce into the Medical School academic customs of the former. The medical class assembled morning and evening for prayers, the professors officiating, and the rigid rules governing the academic department were enforced. These academic customs were discontinued in 1824 with the establishment of the Theological and Law Departments. They are probably without parallel in the history of medical schools.

"In I 835 and subsequently, enlargements and other improvements were made in the medical building, better fitting it for its purposes, especially for anatomical work. At the beginning a few hundred dollars were advanced by the College Corporation to enable the School to begin its work, but later this sum was refunded."-Welch, note 3 o.

In this building, now familiar to all as "South Sheff," or Sheffield Hall, the work of the Medical Department was carried on for forty-five years until in 1859 the property was sold to Hon. Joseph E. Sheffield for a Scientific School, and from the funds thus obtained the present building was erected on York Street, for the accommodation of the Medical School.

According to popular hearsay, this change of location was necessitated by the proximity of the Grove Street Cemetery to the original situation, the belief being current that resurrectionists found it all too easy to introduce subjects for dissection disinterred from New Haven's "Westminster," as the cemetery across the street is sometimes denominated from the great 
number of distinguished men whose remains have been interred there.

Strong feeling against "the cutting up of dead bodies" had made trouble for the Medical School in New Hampshire, as Dr. Smith's letter of May I 4, I 8 Io, testifies, and doubtless all of the early medical schools had to contend against similar popular prejudice and ignorance.

In the spring of 18 1 5 , Dr. Smith was called to his home at Hanover by the extreme illness of his eldest daughter, Sally Malvina, a lovely girl of sixteen years. There seems to have been nothing that the devoted father and skilled physician could do to save the precious life of his child, whose passing to the Better Home on June I 3 is described as a scene of "perfect Christian peace and Heavenly serenity" which impressed all about her with the comfort which faith and trust alone can give.

The influence of the good Bishop Philander Chase must have lingered around his family and friends long after he had left the neighborhood of Dartmouth, for Mrs. Smith and many of the Chase family were earnest Christians. President Allen, of Bowdoin College, stated in his address of I 829 that the death of this dear daughter, following that of Dr. Smith's friend and patient, Mr. Hubbard, Professor of Mathematics at Dartmouth, overwhelmed Dr. Smith with wonder and convinced him beyond all question of the truth and efficacy of religion.

Mr. Hubbard was a cultured and strong man of many accomplishments, whose eloquent expressions of 
trust in his Saviour and of lofty anticipations of happiness in the world he was about to enter impressed all who were around him in his dying hours with the truth and power of religion. Dr. Smith, who was present, did not ascribe this radiance of Christian hope and comfort to "nervous influence or to an inflamed fancyfor Mr. Hubbard was a man of reason and argument as well as of feeling, and his words carried conviction to the mind as well as emotion to the heart."

The death of this daughter was the first break in the home circle and came as a crushing sorrow, never to be entirely outlived, and it must have been harder than ever for the husband and father to leave his bereaved family to go back to work at Yale College; but it is probable that, as the summer was already at hand, he was able to spend the long vacation with them before returning to New Haven.

As has been already stated, he was invited to Dartmouth soon after to give another course of lectures and no doubt his visits to his home and family were not infrequent, although in those days, when there were no railroads or conveniences for rapid travel, journeys were very difficult to accomplish, and long separations must sometimes have been inevitable.

Letters to Dr. Smith's intimate friend, Mr. Mills Olcott, at Hanover, show that he returned to $\mathrm{New}$ Haven in September, I 8 I $_{5}$, having Miss Mary Olcott under his care. In October of that year he wrote to Mr. Olcott: "I am much obliged to you for your kind attention to my family and hope you will continue to look a little after them." 
Again, in January, 1816 , he wrote to the same good friend: "I feel very anxious about my family. I wish you would call on Mrs. Smith and if anything is wanting to make her comfortable during this stormy season, if you will lend her the necessary aid I will remunerate you if I live,-as I trust I shall."

The Junior exhibition of I 816 was held in the Chapel at Yale College, on Tuesday, May 7, when the name of $N$. R. Smith appears on the card of invitation as one of the managers. This photograph of one of the original cards will be found quaint and interesting. It was in this year that Solon took his degree of M.D., an occasion of great pride and interest to the family-and it is probable that his good father at this time appreciated more than ever the necessity of collecting his family into a more settled home.

He therefore gave his final course' of lectures at Dartmouth during that summer, and, declining reëlection to a professorship there, immediately went about making arrangements for the removal of his family to New Haven, which was accomplished early in the spring of 1817 . With efforts and interests concentrated in one place, Dr. Smith began to feel relief from certain anxieties, and having arrived at the zenith of his ripe knowledge and experience, it is said that at no time in his life was he able to accomplish more wonderful work as teacher, writer and practitioner, than in the years which followed this removal to New Haven.

The following rather gratifying testimonial came to him from his pupils in the spring of 1817 : 
"Professor Smith, Sir :

Conscious of your abilities and the exertions you have made in contributing to the improvement of the medical class in the study of Surgery and Practice of Physic the winter past:

We, as in their behalf, acknowledge their entire satisfaction with the Lectures and, with emotions of gratitude and sentiments of much respect, return you their sincere thanks.

Benjamin Trumbull, David S. Edwards,

Committee.

New Haven, March 22, I 8 I 7." 


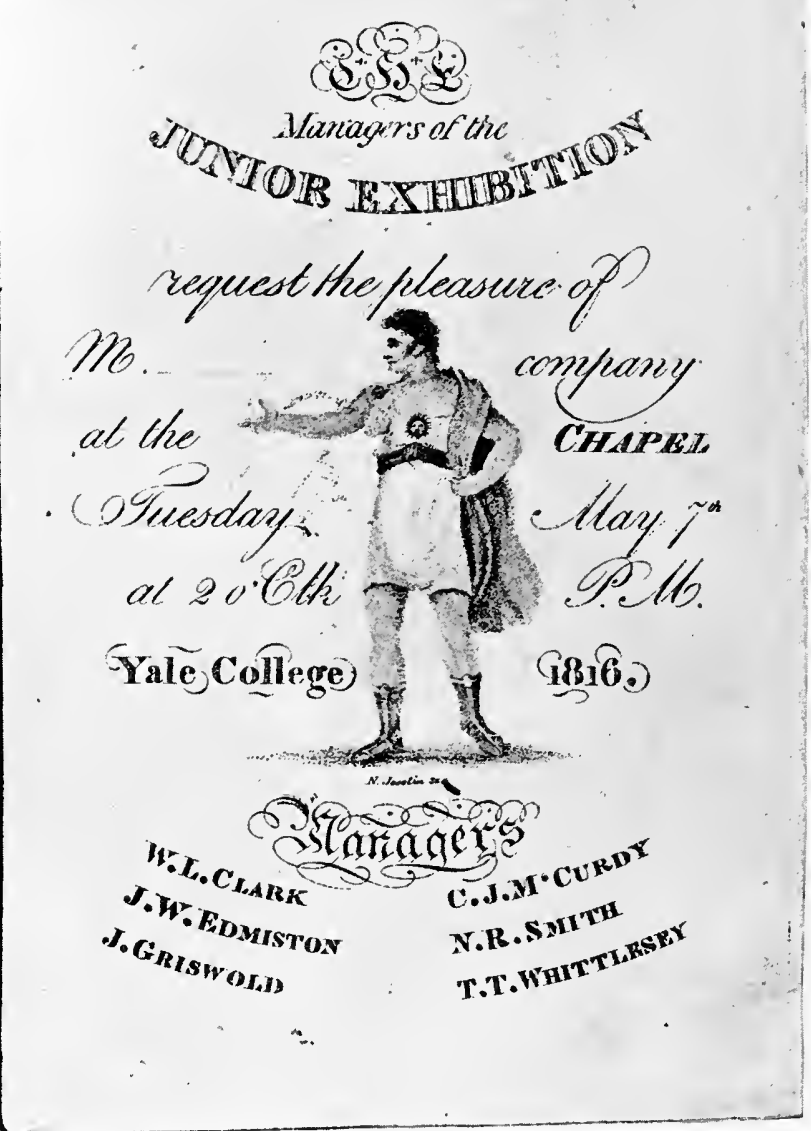





\section{CHAPTER TWELFTH}

The summers of 1816 and 1817 brought events of great importance to the young Smiths. Solon took the degree of M.D. at Commencement in I 816 , for which occasion Nathan Ryno, a Junior of the regular college course, wrote a play called "The Quixotic Philosopher," which was acted, with great applause, by the students, he himself taking a prominent part. The play added much to the entertainment of the members of the college and its visitors, and was said to be very clever, showing great literary talent on the part of its young author. In 1817 Nathan Ryno received the degree of A.B.

Dr. Smith, with his usual promptness in action and his great interest in the future welfare of his sons, immediately after their graduation sought to make the best plans for their advancement in life. For the younger one, Nathan Ryno, he secured a fine position as classical tutor in the family of Mr. Thomas Turner, of Fauquier County, Virginia, a gentleman of wealth and position; but after a year or more there, young $\mathrm{Mr}$. Smith realized that, although he had enjoyed his work as instructor and had formed a strong attachment to his friends of Virginia, and a sympathy and love for the southern people which went with him through life, his tastes were all pointing in the direction of medicine and surgery as his special vocation. He therefore returned to New Haven, and began to study medicine under his 
father and the other eminent professors of the Medical Department of Yale College.

In the meanwhile, Dr. Smith had given Solon rare opportunities for the study of botany by employing a German botanist to travel with him for a year through the western country, which enabled him to classify and know the medical properties of nearly all the plants of the country. He was also a fine naturalist and gave much attention to entomology. Some time later he furnished descriptions of the New England reptiles for President Hitchcock's great work. The two letters to Dr. Shattuck which follow give an idea of Dr. Smith's hopes and plans for Solon.

\section{"Dear Sir:}

I wish for your assistance in a certain way. Solon writes me that he has learnt by the public papers that an expedition is to be fitted out to make an establishment at the mouth of the Columbia River. He wishes, if possible, to obtain the office of Surgeon's Mate in that expedition, which would, he thinks, favour his project for acquiring a thorough knowledge of the Botany and Natural History of North America. Mr. Crowninshield lives in your vicinity, and I wish you to sound him on the subject, and you may state to the Secretary of the Navy, ${ }^{18}$ that Solon has been fully educated in the Science of Medicine, and has studied Botany practically, and is perhaps not behind any one of his age in the United States; and also suggest that

${ }_{16} \mathrm{Mr}$. Crowninshield was Secretary of the Navy only until November, 1818. 
an industrious botanist stationed in that unexplored region, might, besides doing his duty in the service, render this country essential service by his discoveries.

Professor Silliman is now absent, and as soon as he returns, we, the Professors of Yale College, shall make out Solon's certificate and credentials in manner and form, and send them to Mr. Secretary, and also forward them to the Seat of Government.

Please to accept my very great regards for yourself and Mrs. Shattuck and also remember me affectionately to Mrs. Derby. Also present my very great respects to Mr. Elliot and family.

I am with sentiments of esteem yours, \&c.

Nathan Smith.

New Haven, August 3I, I 8 I 8. To Dr. George C. Shattuck, Boston."

\section{"Dear Sir:}

I wrote you a few days since respecting a place for Solon in the Navy or Army; as the hurly burly of Commencement is now over, the subject will be attended to by the Professors and his testimonials will be forwarded to the proper authority; a commission in the Army, if it cannot be obtained in the Navy, will enable him to travel in the Western country, (which he much wishes for), if he can be stationed in that region.

We were much pleased with your pupil, Mr. Wells, who from his modest deportment and amiable manners promises well. Mr. Wells will be able to give you an account of our Commencement. A class of sixty-seven 
graduated and we think the present Freshman class will be considerably more numerous. We do not know how many we shall have in our next class of medical students, but, from the present appearances I think it will exceed any we have had before.

I am with esteem yours, \&c. \&c.

Nathan Smith.

New Haven, September ro, I8r 8. To Dr. George C. Shattuck, Boston."

The history of Sutton, Mass., compiled by the Rev. Messrs. Benedict and Tracy, contains quite a full account of the life there of Solon, from which we gather that the position in the army or navy, which his father so anxiously sought for him, was not obtained, and that he started the practice of medicine in that town in 1819 , when there were already three other doctors in the district. Solon's thorough training and the prestige of his father's fame, however, soon helped to make him one of the most popular physicians in that part of the country.

$\mathrm{He}$ is described as a large man, of fine personal appearance, with great, piercing, gray eyes, which his patients thought could look straight through them and tell exactly what was the cause of complaint.

Sutton had been the home of many of his ancestors, for his great-great-grandfather, Samuel Dudley, descended from the Dudleys and Suttons of England, was the founder of the settlement and the name, Sutton, was given to it in his honor. The Chase grandparents were also residents of Sutton. 
On the 26th of July, I819, the sixth little daughter and tenth child was born to Dr. and Mrs. Nathan Smith. They called the child Sarah, for her mother as well as for the elder sister who had died at Hanover four years earlier.

This advent made the number of Dr. Smith's family complete. A copy of a page from the family Bible, in which Dr. Smith had with his own hand most carefully registered all of the births of his children, may prove of interest here.

Children of Dr. Nathan Smith and His Wife, Sarah Hall Chase Smith.

David Solon Chase Hall Smith was born 27 th June 1795 at 3 o'clock A.M.

Nathan Ryno Smith was born 21st May 1797 at 1 o'clock P.M. Sunday.

Sally Malvina Smith was born Dec. 27th 1799 at 4 o'clock P.M.

Gratia Eliza Smith was born 16th May 1802 at 11 o'clock A.M. Sunday.

Mary Amanda Smith was born 30th Dec. 1803 at 11 o'clock A.M.

James Morven Smith born Sept. 23rd 8 o'clock P.M. in the year 1805. Monday.

Catherine Camilla Smith born July 2nd at 1 o'clock A.M., 1807.
Laura Matilda Smith born on the 3rd day of Dec. 1809 at 2 o'clock in the morning. Sunday.

John Derby Smith born on the 9th day of April A.D. 1812-at 6 o'clock in the evening. Thursday.

Sarah $\longrightarrow$ Smith born on the 26th day of July 1819 at 8 o'clock in the evening. Monday.

Gratia Eliza Smith married Dec. 30th 1822.

David S. C. H. Smith married July 26th 1820 .

Sally Malvina Smith died June 13th 1815. 
It is evident from the above register that marriages of the older children soon began to follow the birth of the little Sarah, and if no other records were left of them, the people of the present day might be left in ignorance as to whom the children married; for the fact that they were married on a certain date seemed to be all that impressed their father, who registered the brief statements. David Solon C. H. Smith married Lucy Hall,-probably his cousin,- - of Sutton, where he continued to live and practice medicine. Gratia Eliza married Rev. I. S. Lincoln, in her father's house at New Haven. 


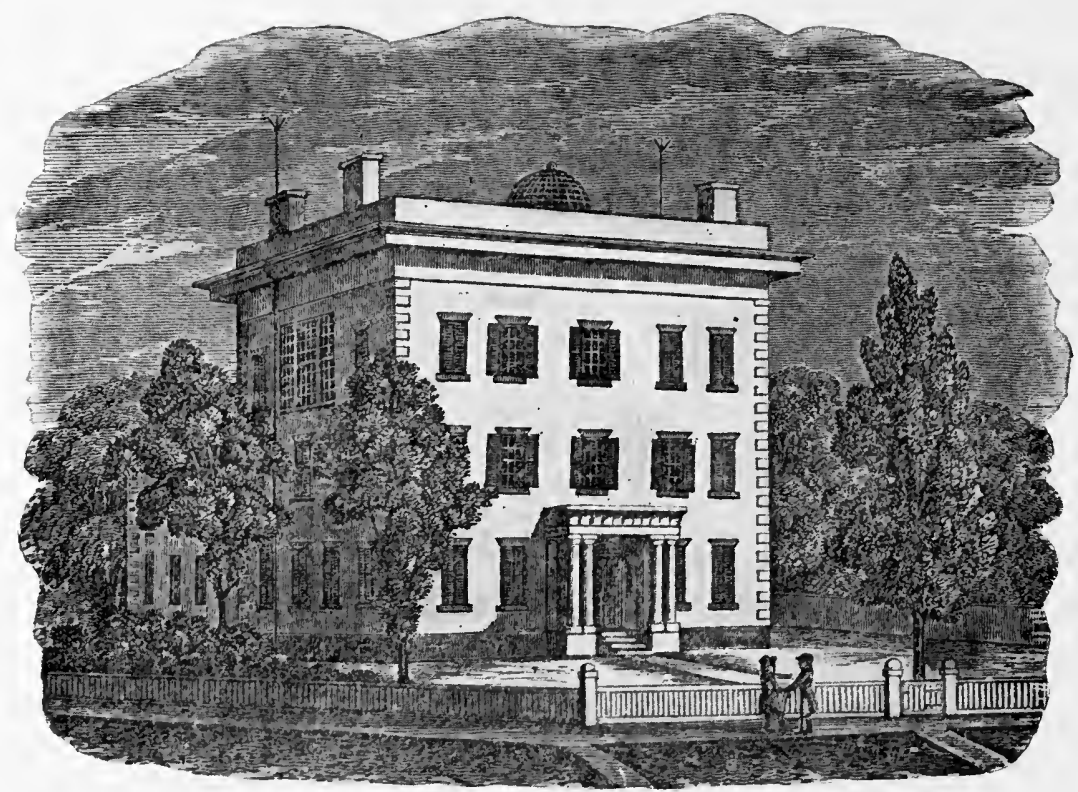

Yale Medical College in 1840 



\section{CHAPTER THIRTEENTH}

In June, I 820,- -according to President Allen of Bowdoin, - the first Legislature of the new State of Maine passed an act establishing and endowing the Medical School of Maine, and he asserts that "the creation of this school may be in no small degree ascribed to the fact, that Dr. Smith had been consulted on the subject of being placed at the head of it." Dr. Allen writes further that: "Before the session of this Legislature, and before I became a resident in this State, I received from him a communication, in reply to a letter suggesting the plan of such a school in Maine, in which he said, he should take great delight in coöperating in such an institution. He added:- 'I think after what experience I have had, we could form a medical school, that would, in point of real utility, equal any in the country.-In a new State like Maine, where neither habit nor party have laid their ruthless hands on the public institutions and where the minds of men are free from their poisoning influence, everything is to be hoped for.'"

Dr. Smith wrote the following letter from New Haven to Dr. Shattuck before taking up his duties in the new Medical School of Bowdoin College at Brunswick, Maine.

Dear Sir :

“New Haven, January 7, I82 I.

I have engaged to go to Bowdoin College and to 
deliver a course of lectures which will continue about ten weeks, for which I am to have six hundred dollars. President Allen has written to me saying that there is a young physician by the name of Arnold who has had considerable experience in dissecting, and wished me to consult him about going on with me, and to ascertain what compensation would satisfy him. It is not probable that his services will be wanted more than five or six weeks. Will thank you to feel of him on the subject, if you think he would be a suitable person, and learn his terms if he is inclined to go with me.

I have one more favor to ask of you, and that is to see if you can find some young man in Boston who would agree to furnish us with two or three subjects. They could be sent to Portland and by water. The College expects to pay the expense and will be willing to give a reasonable compensation. Perhaps some young man who wants cash might be willing to furnish two or three. They will not be wanted till some time in March.

We have a good class of medical students in this Institution, about sixty very respectable young men. I have pushed on my course of lectures with a view to my engagement at Bowdoin. I am through Theory and Practice and have advanced some ways in Surgery.

I shall go to Brunswick by the way of Boston and will then see you; this will be the fore part of next month.

I have performed many surgical operations in the - last year, and some of great importance. My success has been very great as respects curing, and if my 
patients had been of the right sort, my business would have been very good, but alas, many of them have been poor, and the people in Connecticut have no idea of rewarding professional men except by compulsion or by being begged. The lawyers compel, and the priests beg for pious purposes.

Please to remember me affectionately to Mrs. Shattuck, Mrs. Davis and Mrs. Derby.

I am with sentiments of esteem,

Your Obedient Servant,

Nathan Smith.

Dr. G. C. Shattuck, Boston."

From President Allen's address we gather that the Medical School of Maine was opened in the spring of I $82 \mathrm{r}$, the governors of the college having very liberally offered apartments for the purpose in Massachusetts Hall. Dr. Smith delivered the various lectures, with the exception of chemistry, in which branch ample instruction had for many years previous been given at the college by Professor Parker Cleaveland. He was assisted, however, in anatomy by Dr. John Doane Wells ${ }^{17}$ the expert hand which two years afterwards relieved him wholly in that department and in surgery. Dr. Wells was a graduate of Harvard and a pupil of Dr. Shattuck, who in answer to Dr. Smith's letter recommended him for the position.

${ }^{17}$ John Doane Wells, Harvard A. M. 1817, and M.D. 1820; also Berks. Med. Inst. Mass. 1829, afterwards Professor of Anatomy at the University of Maryland. 
There were twenty-one young gentlemen at the first course. The next year they had increased to fortynine. In the year I 829 there were nearly a hundred, and Dr. Allen ascribed much of the success of the school to the reputation, experience and skill of Dr. Smith. In his surgical clinic during the first course he couched nearly twenty eyes for cataract, one eye was completely removed, a leg was amputated, and various other surgical operations were performed, which brought relief to sufferers, while increasing the advantages of the students.

Dr. Nehemiah Cleaveland, in his history of Bowdoin College, states that "Dr. Smith had been the steadfast friend of the venerable Wheelock [of Dartmouth], and though no partisan, he had deeply felt for him in those troubles which saddened his last days. . . . His friendship for President Wheelock extended to the son-in-law [President Allen of Bowdoin], and made him [Dr. Smith] the more willing to give his name and strength to a work which was in other respects congenial to his spirit." Dr. Cleaveland states further: "As I was at that time studying medicine, I joined the class [of $182 \mathrm{I}$ ], attended the lectures, was present at most of his operations in the neighborhood, and saw much of him in general society. The course over, I accompanied him, in that most sociable of vehicles, a one-horse chaise, on a professional tour to Wiscasset and up the Kennebec. Of my intercourse-at once pleasing and profitable-with that great man the impressions are still vivid. . . .

"Dr. Smith was a large man. . . . His expression 
and genial countenance, his very attitude and air, were admirably caught by the great artist who fixed them on his canvas, and whose picture will reproduce his image to all who knew him. . . ${ }^{18}$ There was no show of learning, no attempt at brilliancy, no assumption of dignity or superiority. The admiration which was felt for his ability and wisdom - a feeling shared by all who knew him-could be accounted for only by his possession of those attributes."

18 The portrait here referred to is supposably the well-known one painted by Samuel Finley Breese Morse for the Yale Medical School Class of 1826, a copy of which appears opposite title page of this book. This picture, Professor Silliman says, is "esteemed one of the best works of that artist." Morse's fame as a portrait painter has been so eclipsed by that of his later achievements as inventor of the telegraph that his work as an artist has not had the prominence in the popular mind which it merited. 


\section{CHAPTER FOURTEENTH}

The summer course of lectures at Bowdoin did not in any wise conflict with the regular work of Dr. Smith at New Haven, for that city continued to be the theatre of his most important professional achievements as physician, surgeon and teacher of medicine, and it was during the time of his connection with Yale that he performed some of his most remarkable operations.

It was on July 5, I82 I, at Norwich, Vt., that he performed the extraordinary operation of ovariotomy, which should in itself have rendered his name famous and which would, doubtless, have been associated with him but for the fact that McDowell in Kentucky had performed a similar operation some nine years previous, although of this Dr. Smith had no knowledge.

Such an authority as Dr. Gilman Kimball of Lowell, Mass., says: "Ephraim McDowell, as has been already said, will be regarded in all time to come as the "father of ovariotomy,' and as one of the master spirits of his profession. It was my privilege to be present at the dedication of the monument to him, and to listen to the words I have just quoted as they fell from the lips of the orator on that occasion.

"Doubtless, in point of time, the credit should be given to the Kentucky surgeon as having been the first ever to successfully perform the operation of ovariotomy.

"But I believe I should be guilty of a great injustice 
to the memory of Dr. Nathan Smith did I not insist upon this fact, that has already been almost forgotten, and place upon the imperishable page of history the assertion which I think every candid reader will admit -viz., that, in point of absolute merit, Dr. Nathan Smith is entitled to the same honors that have been accorded to Dr. McDowell. Nor was his first operation an accidental one, as has been intimated, but the result of calm, deliberate study of the laws of vital action, like all the rest of his surgery; there was as much of John Hunter in it as in any action of John Hunter's life."

In the same address Dr. Kimball says:

"It is claimed, and justly, I suppose, that he was the first to perform staphyloraphy in this country. As an operator, he was cautious and painstaking, and is said never to have lost a patient from hemorrhage, either primary or secondary. His ingenuity and manual adroitness are especially deserving of notice on account of his introduction of a new method for reducing dislocations of the hip joint by what is known as the manœuvre system, 'which is as useful as it is simple, and as scientific as the principle of flexion and leverage, on which it depends.'

"The incident by which Dr. Smith came into possession of a clew to this important discovery is but another illustration of the truth already declared, that the most beneficial results to mankind have been those which have been educed from the slightest circumstance, which the thoughtless might consider a mere trifle or accident. This fact, as related by the late Professor 
A. B. Crosby, is as follows: 'While residing at Cornish he had a friend who was a sea-captain, and who, on returning from foreign voyages was wont to relate to him whatever of interest in a medical way he might have chanced to observe while abroad. On one occasion he told Dr. Smith that on his previous voyage one of the sailors dislocated his hip. There being no surgeon on board, the captain tried, but in vain, to reduce it. The man was accordingly placed in a hammock with the dislocation unreduced. During a great storm the sufferer was thrown from the hammock to the floor, striking violently on the knee of the affected side. On examination, it was found that in the fall the hip had somehow been reduced. This interested Dr. Smith wonderfully, and he questioned the narrator again and again as to the exact position of the thigh, the knee, and the leg at the time of the fall.'

"From a careful study of 'this apparently insignificant circumstance,' Dr. Smith demonstrated the reducing of dislocation of the hip by the 'manœuvre method,' so called, now almost the only one resorted to."

The Medical School at Yale continued to grow in reputation and in numbers during these the busiest years of the life of Nathan Smith. In the ledger he kept in 1821 are notes of some of his lectures, which show his extreme care in giving instruction, as likewise his own steady growth in knowledge and experience, preparing him to write for the world his invaluable essays on fevers, necrosis, etc., which, according to scientific men of to-day, marked him as a hundred years 


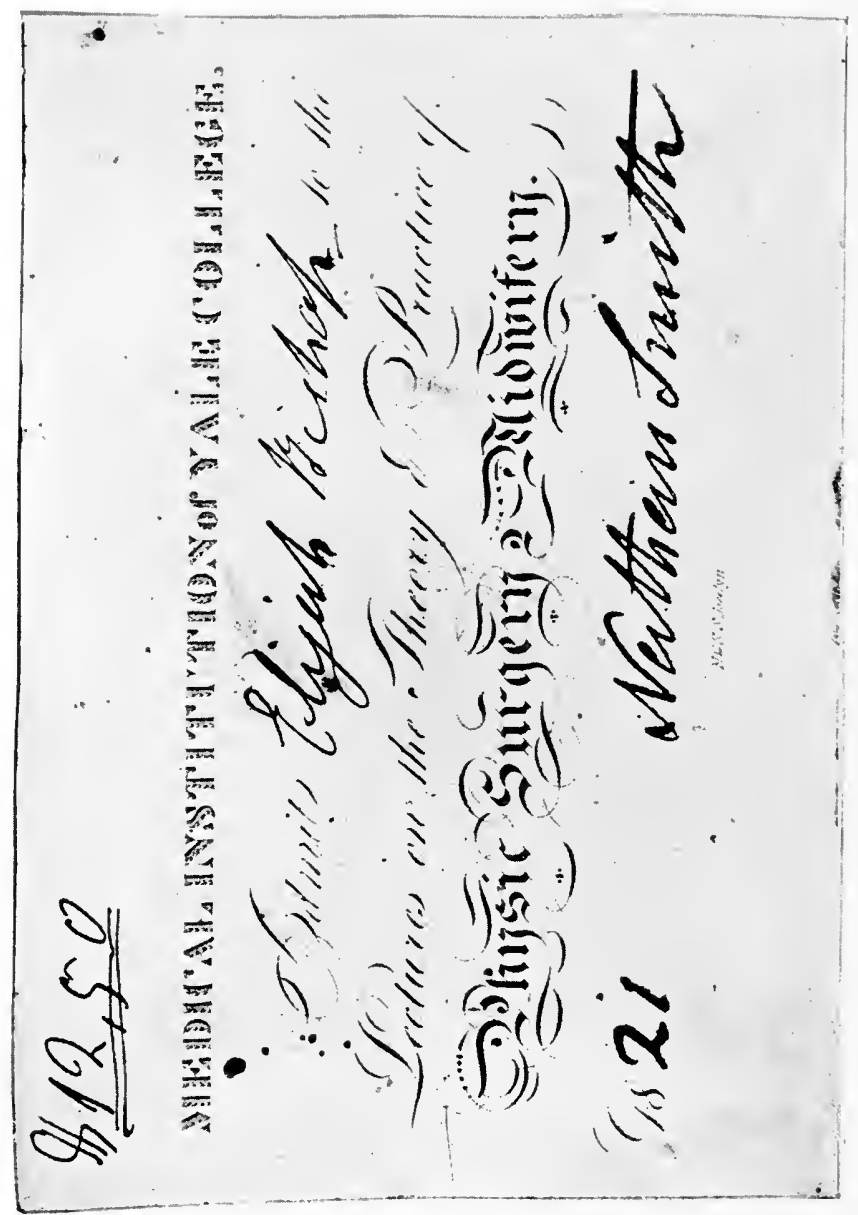



ahead of his times. In the same ledger are recorded the following names of the medical students of Yale in I82I and 1822 . The accompanying photograph is from the original ticket to Dr. Smith's lectures, of Dr. Elijah Bishop, one of the students of I $82 \mathrm{I}$.

From Dr. Smith's ledger, kept at New Haven in I $82 \mathrm{I}$ and I 822 , the following lists of students' names are taken.

Benj. Welch Jr.

Timothy Dimock.

H. Everitt.

Solyman Russell.

Heminway.

Miller.

Case.

George W. Walcott.

D. S. Hart.

Charles Smith.

George Gary.

Joseph G. Knapp.

Asahel Jones.

Edward Dickinson.

Horatio N. Fenn.
Edward York. John A. Paine. William Powell. Amos W. Gates. Charles Hooker. Increase Harrison. Wyllys Woodruff.

J. B. Irving.

George Taylor. Ephraim Little. Norman Bull. Henry Holmes. B. Mawry. Eben West.

Edward Leffingwell.

Catalogue of Students in 1822, Who Have Taken Tickets.

Thomas A. Dutton.

Joseph Camp.

Henry Hewitt.

Henry Lee.

Samuel H. P. Lee, Junr.
Alexander Wolcott.

Thomas Wilbur.

Benj. B. Coit.

$Z$. W. Bingham.

Abraham L. Smyth. 
John H. Arnold.

Datin Williams.

William O. Talcott.

Chester Hamlin.

Garry H. Minor.

Ulysses W. Mather.

H. Cleveland.

Samuel W. Pratt.

Asa H. King.

E. S. Trowbridge.

Titus C. Pratt.

Samuel D. Carver.

Chester Griggs.

Nelson Carpenter.

Alden L. Skinner.

A. P. Beers.

Edward P. Terry.

Gustavus A. Rogers.

Lemuel Wick.

Curtis Prentice.

Sheldon Lemon.

Samuel Woodruff.

Isaac Beers.
Theodore Gilbert.

Asa Witter.

J. G. Pierce.

W. H. Cogswell.

William H. Huggem.

Thomas H. Klien.

Walter H. Olcott.

Robert G. Huntington.

Samuel W. Brown.

Earl Loomis.

Elijah Bishop.

J. P. Haynes.

William Henry Cleveland.

Richard H. Eastman.

D. B. Shelton.

Samuel McClellan.

Henry B. Porter.

Charles Rowland.

B. F. Cleaveland.

Solomon P. Cushman.

Orson Osborn.

Samuel W. Gaylord.

Thomas O. H. Carpenter.

Although Dr. Smith was doubtless free from partiality for one son above another, it is quite clear that from the time "Ryno" passed the fine examination in arithmetic at Hanover through the period when he stood one of the first in his class at Yale, the father's natural pride continued to grow and centre around this talented son who seemed to have inherited many of his own tastes for the medical profession and who 


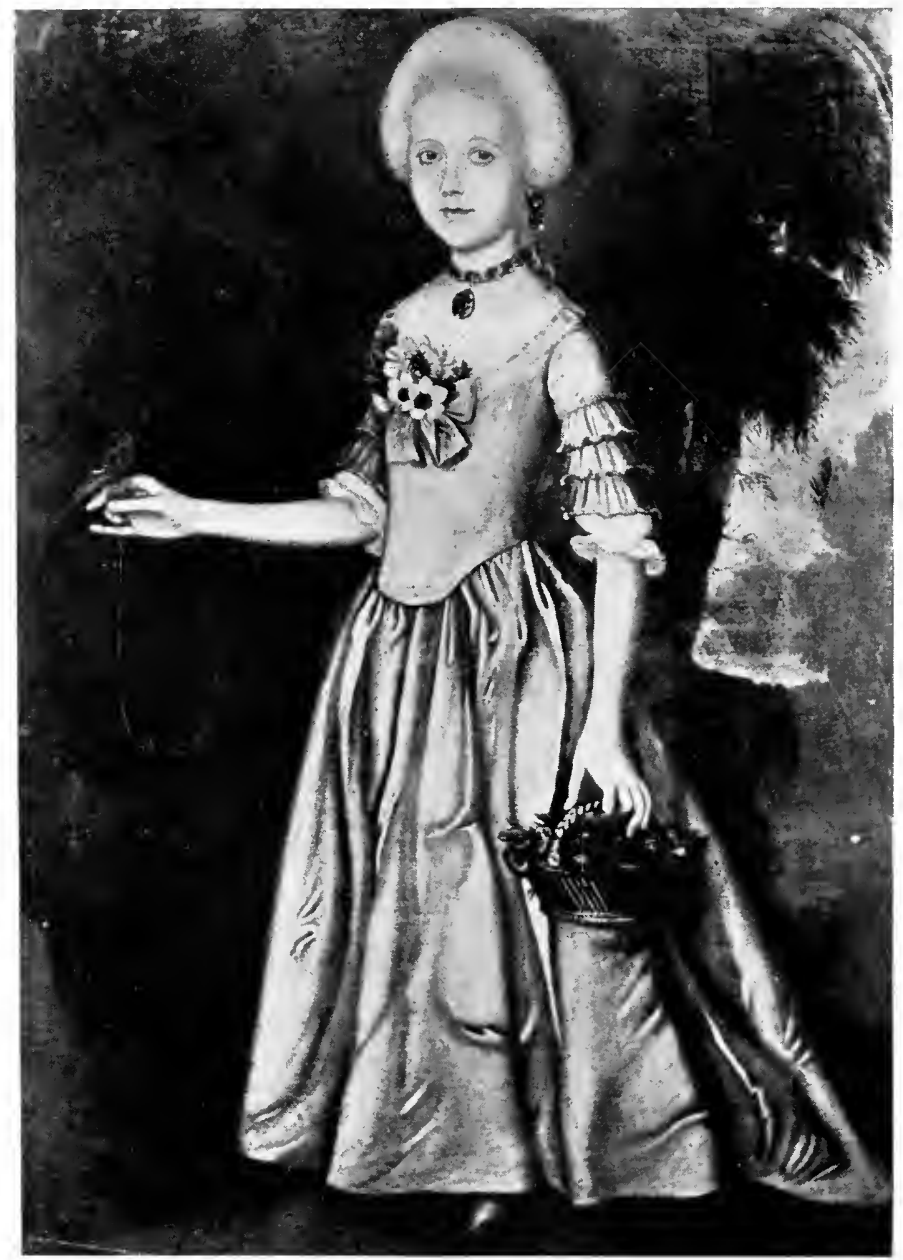

Mrs. Frances (Montesque Buchanan Allen) Penniman The mother of Mrs. Nathan Ryno Smith

Portrait by Copley when she was nine years old 

showed much perseverance in making progress under difficulties.

Solon had married early and was practicing medicine in Sutton, Mass., James Morven was but fifteen years of age, and John Derby was only a little lad of eight years when Nathan Ryno Smith received the degree of M.D. from Yale in 1820 .

Soon after graduation in medicine, Dr. N. R. Smith removed to Burlington, Vt., and there married Juliette Octavia, the daughter of Dr. Jabez Penniman. Mrs. Nathan Ryno Smith was a woman of beautiful character and strong personality. Her mother and grandmother were quite noted in Revolutionary days, the mother before her marriage to Dr. Perriman having been the second wife and widow of General Ethan Allen, and the grandmother, after the death of Monte Montesque, having married the well-known Tory, Crean Brush. The photographs of their interesting portraits are here given.

In the early part of the nineteenth century the impulse given by the elder Dr. Smith toward advancement in the knowledge of medicine and surgery had extended throughout the country, and the necessity for good medical schools began to be felt in many states.

The University of Maryland was first to follow Dartmouth and established its school in 1807 . Then, in rapid succession during the next ten years, five other medical schools sprang into existence, headed by that of New Haven in I 8 I 3 .

According to Professor Benjamin Silliman: "In order of time the Medical Institute of Yale College 
was the sixth established in the United States. The medical schools of the University of Pennsylvania and at Columbia College were instituted in 1768 ; that at Harvard in 1782 ; at Dartmouth in 1798 ; and in the University of Maryland in 1808 . But prior to $18 \mathrm{ro}$, Columbia had sent out only 35 graduates in medicine, and from r8 ro to 1860 none. Harvard graduated only 54 students [59 according to recent catalogues] prior to I8r3, when Yale came into the field."

Bowdoin's medical department at Brunswick, Me., was started by Dr. Nathan Smith in I 82 I and a few months later the University of Vermont established its medical department at Burlington and called to the Professorship of Surgery and Anatomy, Dr. Nathan Ryno Smith, through whose exertions, aided by those of his father, the school was organized.

While still faithfully discharging his duties at Yale and at Bowdoin, Dr. Nathan Smith visited the Burlington school and not only delivered courses of lectures there, but by constant correspondence with his son, gave it the benefit of his wisdom and experience, thus, as the colleague of his son in the enterprise, aiding in the establishment of a fourth medical school in New England. 


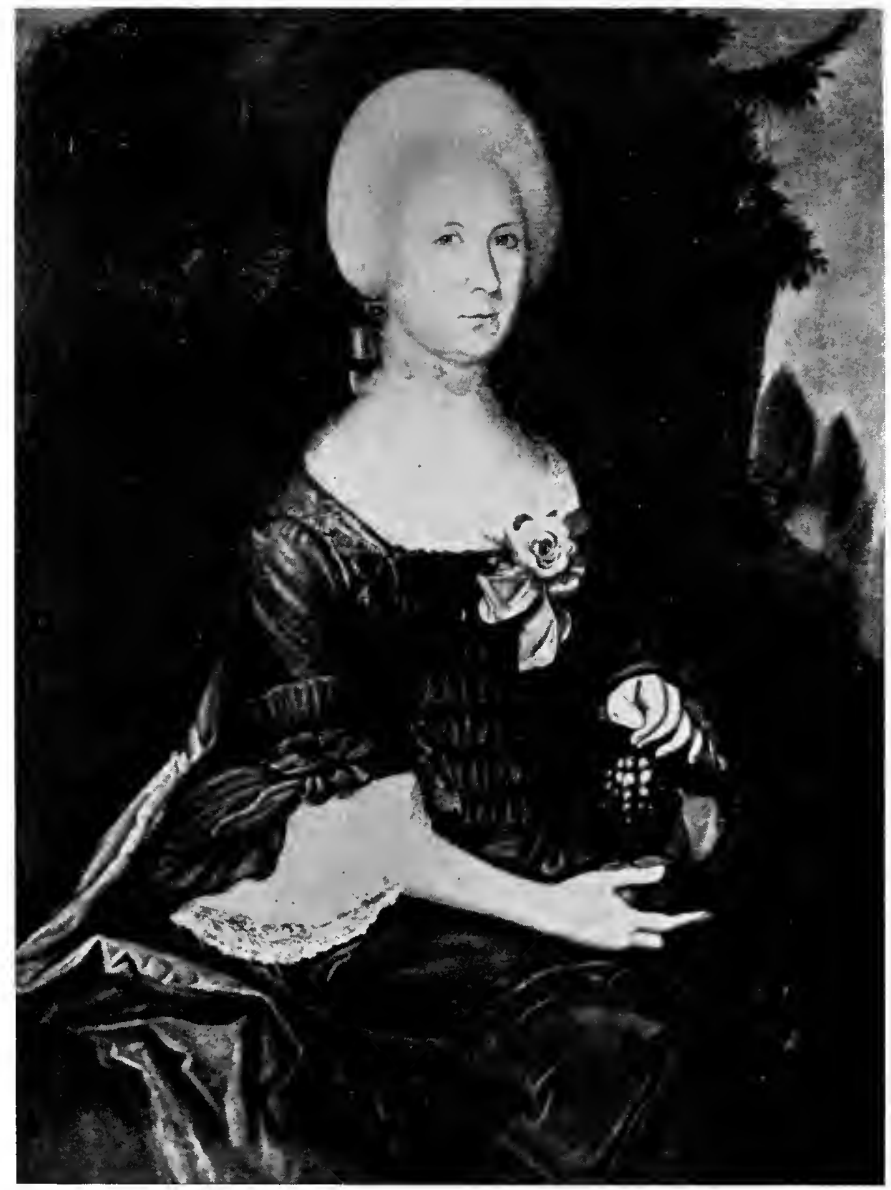

Mrs. Margaret (Schoolcraft) Montesque Wall The grandmother of Mrs. Nathan Ryno Sinith Portrait by Coptey 



\section{CHAPTER FIFTEENTH}

Three interesting letters from Dr. Nathan Smith to Dr. Shattuck will give an idea of his wonderfully busy life. Writing from Brunswick, Me., and from New Haven, he mentions the completion of his Treatise on Fevers and also speaks of his intention of spending some weeks in Burlington, Vt., where he will deliver a course of lectures, which he hopes may be the last he will be called upon to give outside of New Haven.

From Brunswick, April i 8, I 823, Dr. Nathan Smith writes to Dr. Shattuck in Boston:

\section{"Dear Sir:}

I left a chaise at Middletown in Connecticut with orders to send it by water to Boston, and directed that it should be sent to your care. If it arrives I wish you to turn it over to James Mann \& Co., India street, with orders to send it on by some of our coasters who ply between Brunswick and Boston; or, if it is more convenient to send it to Bath, it will answer my purpose. If there are any charges from Middletown to Boston I will thank you to pay it. Send the bill in a letter to me and I will pay it to you.

Our course of lectures go on very well and I believe will be very satisfactory to the class, which is without exception the best class of medical students $I$ have seen together.

I have written out a treatise on Typhus Fever and 
Mr. Bell is copying it for the press. I shall also, before I leave this, finish a book on Surgery which will contain about two hundred pages, which I shall publish in the course of the present year.

Dr. Wells gives a very good course on Anatomy, and is popular with the class. I think the school is now established. The next year will decide the fate of the school at Burlington. We made a very good beginning last year, and if no untoward circumstance occurs I think it will live. I think the four schools which I have been concerned in bringing forward in addition [to Harvard], will be as much as New England will bear, and I think there will not be too many. Every State should have one medical school and no more. A medical school does more towards ameliorating the condition of mankind than any other institution, as the knowledge acquired in them is of more practical importance.

Professor Wells and Mr. Bell send their best respects to you and your family.

I am, with great esteem,

Your Friend and Humble Servant,

$$
\text { Nathan Smith."” }
$$

A few weeks later he writes to the same friend:

"Dear Sir:

Your letter respecting the chaise has been received. I have enclosed you five dollars for the freight to Boston. 
I have still another favor to ask. Dr. Wells informs me that you have Cooper's newly invented instrument for extracting the stone through the urethra. We have a case in this village which I think is a proper one for such an instrument, and wish, if you are willing, that you would send it to me by the captain of the vessel who may bring my chaise and I will immediately make use of it and send it safely to you. I have two objects in view, one to relieve the patient, and the other to show it to Mr. M. Eastman, a man of great ingenuity, who, I think, having seen one, can make another like it. If the chaise is already sent, and if you should be willing to oblige me, I wish you to send it by the first safe hand, and if you have an opportunity to send it to Portland sooner than to Brunswick, please to send it to the care of Dr. Merrill of Portland, as I am going to Portland to-morrow and shall probably be detained there the whole week as a witness in a case of alleged murder. If any gentleman was coming to Portland in the stage who would be willing to take charge of it, I can receive it there.

I am, with sentiments of great esteem,

Your obedient Servant, Nathan Smith.

Brunswick, Sunday, May 5, 1823. Dr. G. C. Shattuck, Boston."

Dear Sir :

"New Haven, August I6, I824.

I have sent you a manuscript translation of a French 
work on the diseases of the ear, by Dr. J. Bell. I was to have brought it with me last winter, but owing to my present illness I did not, and it escaped my recollection till my return home and till I happened to find it in my house. It was Dr. Bell's request to have it sent to you for your opinion of the work, as to the propriety of printing it, \&c. I wish you would peruse it and then give it to Dr. Wells with your opinion of it and request him to send it to Dr. Bell by a safe conveyance.

I have just located myself in the Medical House which is fitted up in good style and makes me a very commodious house for my family. I have agreed to go to Burlington for six weeks, which will be the last time probably that I shall leave New Haven for the purpose of lecturing in any other place.

N. B. The direction on the wrapper for Dr. Bell is not correct now as he does not live where he did when that was written. I presume Dr. Wells will know how to direct to him.

I am with esteem,

Your obedient Servant,

Nathan Smith.

Dr. G. C. Shattuck, Boston."

The next letter in point of date from the elder Dr. Smith to Dr. Shattuck is the following, written from Solon's house at Sutton, and is too amusing to be omitted from the collection. Truly the care of clothes seems to have given as much trouble in old days as it does now. 


\section{Dear Sir :}

"Sutton, June 29, I 825.

By mistake your folks put up one of your white collars and vests with my clothes, and by the same chapter of mistakes, I believe one of my vests with three pair of linen socks were left at your house. I had the misfortune to leave your vest at Black's Tavern in Providence, but have ordered it to be brought to my son's in Sutton and from there to be sent safely to you.

Now if my clothes should be found in your house, I wish when you have a convenient opportunity you would send them to Mr. Lincoln in Gardner.

\section{Yours with esteem,}

Nathan Smith.

Dr. G. C. Shattuck, Boston."

Anecdotes of Dr. Smith's kindness and humor are still current among some of the families of New Haven, where his visits were looked forward to with eagerness not entirely due to hope of relief from pain. A descendant of the family of Mr. Woolsey, who so cordially received Dr. Smith into his household upon his arrival in New Haven, remembers hearing many amusing tales of Dr. Smith from her mother, and says that it would be impossible now for any physician to hold toward his patients the relation then sustained by Dr. Smith to those who sought his assistance.

On every conceivable topic his opinion was asked and looked upon as the ultimate authority, and his humorous accounts of happenings of the day often 
helped as much as his prescriptions in restoring his patients to health. His kindness to the poor took many forms, most frequently that of professional attentions and ministrations entirely without hope of reward.

He was called one day to a neighboring town where an explosion had taken place, so shattering a poor man's leg as to require its amputation. The $\$ 50$ fee demanded by the doctor having been collected from the crowd of sympathizing bystanders, the operation was performed. At its close Dr. Smith handed to the patient the money, duly counted, and rode away.

Another tale related of him shows not only his pleasure in a harmless joke but his entire absence of affectation, with a most pleasing modesty in reference to his own reputation. "One day he was riding through Guilford, a few miles east of New Haven, when a woman came out of a house and asked if he knew Dr. Smith, and if he were in New Haven, and explained that there was a case there requiring his attention. $\mathrm{He}$ inquired the particulars, and said: 'I know Dr. Smith very well; he is not in New Haven, but I can attend to this case just as well as he can.' He did so, performed the necessary operation, and rode away without telling who he was."

His direct fashion of saying things is illustrated in the way in which he treated the case of a student by the name of Lincoln, who came to Dr. Smith for medicine soon after his family had joined him where he was then living in Wall Street. The doctor's daughter was frequently seen by young Lincoln when 
he called, and the medicine, strange to say, instead of curing him, seemed to create a necessity for more. Finally the doctor said to him one day, "I believe, Lincoln, you don't want any more medicine. It's my daughter you want." The doctor's diagnosis proved to be correct and Mr. Lincoln was married to Miss Gratia Eliza, Dr. Smith's oldest living daughter, immediately upon the young man's graduation.

It is not surprising, in view of the illness to which Dr. Smith alluded in one of the letters just recorded, that the commodious and comfortable quarters fitted out for him and his family in the Medical Building at New Haven, should offer for him attractions stronger than he had ever before felt for a home, and that, at the age of sixty-five years, he began to long for a rest from his journeys and strenuous efforts in behalf of distant medical schools.

In this wonderful age of rapid transit, it is almost impossible for us to realize the magnitude of the work accomplished by that great man of a hundred years ago, now that distance is so nearly annihilated by immense floating palaces crossing vast oceans in a few days, while long trains drawn by steam or electric power take travelers from place to place at the rate of fifty or sixty miles an hour, broad rivers forming no obstacle to their speed. Men are now even successfully undertaking to fly through the air, and it would seem as though the Prophet Nahum had looked far beyond the future of Nineveh, and even to the automobiles of our day, when he said: "The chariots shall be with flaming torches . . the chariots shall rage in the 
streets, they shall jostle one against another in the broad ways: they shall seem like torches, they shall run like the lightnings." And doctors of our day are not behind other men in the use of these cars which run like lightnings.

In Dr. Smith's time, a little sailing vessel took many weeks to bear him across the Atlantic to what was then a far-away land which he visited in pursuit of knowledge. Slow stages took him to distant places by land, and small boats by water, and for visits to patients nearer home his only dependence was his one-horse chaise or his faithful horse. It seems almost incredible that under such circumstances, while his home was at Cornish, he could have successfully established a medical school at Hanover, and that later, while living at Hanover, he should have helped to found the Yale School and have delivered lectures there during four winters before moving his family to New Haven, and further, while still holding his professorship at Yale, aided in establishing the medical schools at Brunswick and Burlington. It must be remembered, too, that founding these medical schools, and delivering a vast number of lectures, were only a part of his achievements; for he visited many meetings of State Legislatures in behalf of his colleges, while his medical and surgical practice extended to almost every part of New England. His wonderful writings, too, while not imposing in point of number, are reckoned among the classics of his profession and are still instructive even in this advanced age.

During Dr. Smith's experience as a teacher of medi- 
cine he gave, according to Dr. Hubbard, some fortytwo general courses in the thirty-two years from 797 to 1828 , giving instruction in about a hundred and thirty-eight special courses. Dr. Welch tells us that the period of greatest prosperity of the Medical School at $Y$ ale until quite recent years was the first two decades of its existence, this being precisely the time of Dr. Smith's connection with the school.

Varied and widespread as were the interests of Dr. Smith, it is gratifying to those connected with the Medical School at Yale to feel that, at heart, he must have cherished a special affection for their institution, for at his death he bequeathed to it his library.

Dr. Nathan Smith ranks second in time among ovariotomists, having performed an original operation at Norwich, Vt., July 5, I 82 I, with no knowledge of McDowell's operation. Out of thirty cases of lithotomy, only three were fatal. He lost no patient of hemorrhage consequent upon an operation, and he first in America performed the operation of staphyloraphy.

"In reference to necrosis, amputation of the thigh, reduction of dislocation of the hip, and treatment of fractures, his principles and devices were new and valuable."

Professor Knight of New Haven was assuredly not exaggerating when he wrote in I829, that "to Dr. Smith is justly due the credit of having introduced and diffused over a large part of New England, the most correct practice, of all the celebrated surgeons of the last and present century." 


\section{CHAPTER SIXTEENTH}

Dr. Smith's interest in establishing schools of medicine did not subside with creating the four schools in New England, for his services were deeply enlisted in the founding of the Jefferson Medical School of Philadelphia, in I 825 , by his son, Dr. Nathan Ryno Smith, and Dr. George McClellan.

They depended much upon his influence and splendid judgment and turned to Dr. Smith and his friend, Dr. Shattuck, for contributions of articles for the American Review, a publication issued from Philadelphia in 1825 .

The Jefferson Medical School under the auspices of the two young professors made.a brilliant opening with I 10 or I 20 students, and two if not more of the number attained a world-wide reputation in their profession. "One of these was the illustrious head of American surgery, Professor Samuel D. Gross, and another was Dr. Washington L. Atlee, the distinguished ovariotomist, whose labors in the advancement of American gynæcology are everywhere held in deserved honor."

Although great credit for the success of the Jefferson School was due to the young Dr. McClellan's skill and energy, there is no doubt that the help and encouragement of Dr. Nathan Smith back of his son (Professor of Anatomy), did much to promote the interests of the work, and this again shows how widely his influence already extended. 
That his stupendous professional work was accomplished while burdened with unusual family cares and great difficulties in financial arrangements, will be shown by the following letters:

\section{Dear Sir :}

"New Haven, January 6, I 826.

I want three hundred dollars to enable my son at Sutton to pay for a house and land which he has purchased, and if you will loan that sum to him and me with our joint security, I will see it forthcoming to you in the month of June next. I have about six hundred dollars in endorsed notes at Brunswick and shall solicit Dr. Wells, when he goes to Brunswick again, to get it for me. I think one half will be paid this winter, but if it should not, I can make up the deficiency.

We have a pretty respectable class this winter, both as to numbers and deportment, and think we shall retrieve what we have lost in character from want of subjects, \&c. Since I have made known my determination not to go, abroad any more to give lectures, my business in this city has increased and is increasing. I have had a good deal of surgery this winter, a part of which has been before the class.

When I was at your house I left there a report of the trial between Hawks and - Some of our fraternity here having seen some sparring about the case wish to see the report, and if you can put your hands on it, will thank you to send it by the mail or otherwise. For myself I care very little about it or what the newspaper folks say about it. 
I believe N. R. is getting on very well at Philadelphia. They have I IO students who pay $\$ 15$ each, which is much better than I expected. John Derby goes to a Latin school in this town, and is a fine scholar and bids fair to make a most excellent speaker. I calculate to have him enter college in a year from next Commencement. Some time between now and that time, when your George is at home, should like to have him spend a few weeks with you.

The failure of Eagle Bank, has given a great shock to New Haven, and though I did not lose but twenty dollars which happened to be in the bank at that time, yet it has hurt me much more than that by making my debtors poor. Upon the whole it has been one of the most scandalous transactions that could be conceived, and all perpetrated by a single individual who, so far, appears to be perfectly indifferent as to its consequences. ${ }^{19}$

I am, with sentiments of esteem,

Nathan Smith.

Dr. Geo. C. Shattuck, Boston."

19 Happily the verdict of later years was such as to make these statements seem erroneous as far as moral obliquity on the part of the president was concerned. Dexter's Biographies give this account of him:

"George Hoadly, born December 15, 1781. After graduating [at Yale in 1801] he studied law in New Haven with the Hon. Charles Chauncey, and from March, 1803, to Commencement, 1806, held the office of tutor in the college. Editor in Washington, later returned to New Haven and entered on practice of law with promise of unusual success. Mr. William W. Woolsey, a retired merchant of New York, who had settled in New Haven, became much interested in Mr. 
"New Haven, April 22, I 826.

\section{Dear Sir :}

In my letter to you last winter respecting my dues at Bowdoin College, I made a mistake of two hundred dollars, which leaves me but $\$ 400$ due there, and from a letter I received from $\mathrm{Mr}$. Cleaveland some time since, I fear there will be more delay about paying that than I expected. I have written to $\mathrm{Mr}$. Cleaveland stating that I should expect the notes to be put in suit immediately or that the Board approve the debt and pay me the money. The notes are given to the Faculty of the College. What they will do about it I do not know; be that as it may, I can pay the money to you if necessary, about, or not long after, the time proposed.

Please to give my very greatest respects to Mrs. Derby and accept a large portion of my respect and esteem for yourself and family.

\section{Yours, \&c., \\ Nathan Smith.}

Dr. G. C. Shattuck, Boston.

I think I shall visit Boston in the month of June or July on business in that quarter. I have very flattering

Hoadly, and, as president of the Eagle Bank, which was incorporated in 1811, and which commanded a large share of public confidence, he unhappily persuaded his young friend to give up his profession and become cashier of the bank. Mr. Woolsey returned to New York in 1815 and Mr. Hoadly succeeded to the presidency, which he held until the disastrous failure of the bank in September, 1825. The president and directors had loaned on insufficient security an amount equal to the entire resources of the bank, and inevitably great indignation was 


\section{Life and Letters}

accounts from the new school in Philadelphia. They have a charter sanctioned by act of the Legislature and passed into a law, so that the old school ${ }^{20}$ cannot put them down as they intended. They had $\mathrm{r} 20$ students last winter and I think may have 200 the next term. I have reason to believe that Ryno is gaining in reputation. Solon, I believe, is doing a handsome share of business."

felt toward the president, though it was afterwards conceded by most witnesses that his error was one of judgment only, and that he derived no profit from the losses of others. Mayor of New Haven, 1822-1826. In 1829 settled in Cleveland, and had a useful and honorable career there. He was remarkable for evenness of temper and kindliness of disposition. Married in New Haven, November 8, 1819, to Mary Anne, eldest child of W. W. Woolsey and Elizabeth (Dwight) Woolsey (sister of President Woolsey and niece of President Dwight)."

20 The Medical School of the University of Pennsylvania. 


\section{CHAPTER SEVENTEENTH}

The success which attended the opening of the Jefferson Medical School was phenomenal and young Dr. Smith showed no flagging of enthusiasm, though burdened with work and responsibilities. Like his father, he did not regard the duties of his professorship of Anatomy as a reason for not taking up other useful work, and he became the founder of the Philadelphia Monthly Journal of Medicine and Surgery, and associate editor of the Medical Review, afterwards merged with the American Journal of the Medical Sciences. But in I 827, after two years of work in Philadelphia, his ambition was aroused by an invitation from the School of Medicine of the University of Maryland to become its Professor of Anatomy, of which chair he effected an exchange with Dr. Davidge, before the lecture season began, for that of Surgery.

$\mathrm{He}$ and his father recognized that far greater advantages presented themselves for his future in this more important branch in the older school already holding a "wide celebrity throughout the South and West." Therefore Dr. N. R. Smith concluded to sever his connection with the Jefferson School and accept the appointment. Accordingly, early in the autumn of that year he repaired to Baltimore and made ready to deliver his first course of lectures, which was attended by a very large class.

By this move of N. R. Smith to a southern city it is 
easy to trace the ever widening benefit to the country at large of the magnificent work of the first Nathan Smith, whose careful and splendid training in medicine and surgery enabled the son to carry to a still more remote neighborhood some of the wealth of wisdom and medical knowledge gathered at the feet of his distinguished father.

Truly the father's pride must have been more than gratified in witnessing the steady progress towards fame of this son and namesake, even if, as the following letter shows, the young doctor had not found time to write to him for some weeks after his removal to Baltimore.

It is pleasant to find a mention of each of the four sons of Nathan Smith, in this, his last letter to Dr. Shattuck, and to read between the lines of the peace which was evidently crowning his life of labor. Although still teaching and writing and accomplishing as much in a quiet way as in any year of his life, he had ceased his tremendous journeys over the country and, surrounded by his wife and younger children, was enjoying his comfortable home life at New Haven.

Dear Sir :

"New Haven, December 8, I 827.

Your favor of the $5^{\text {th }}$ inst has been received. Mr. Hull informed me by letter that he had left \$ I 50 with you and I have given Mr. Crenshaw, my son-in-law, an order to receive it. It gives me great pleasure to hear that your family and Mr. Derby are in good health and prosperity. I wish very much to visit my good friends 


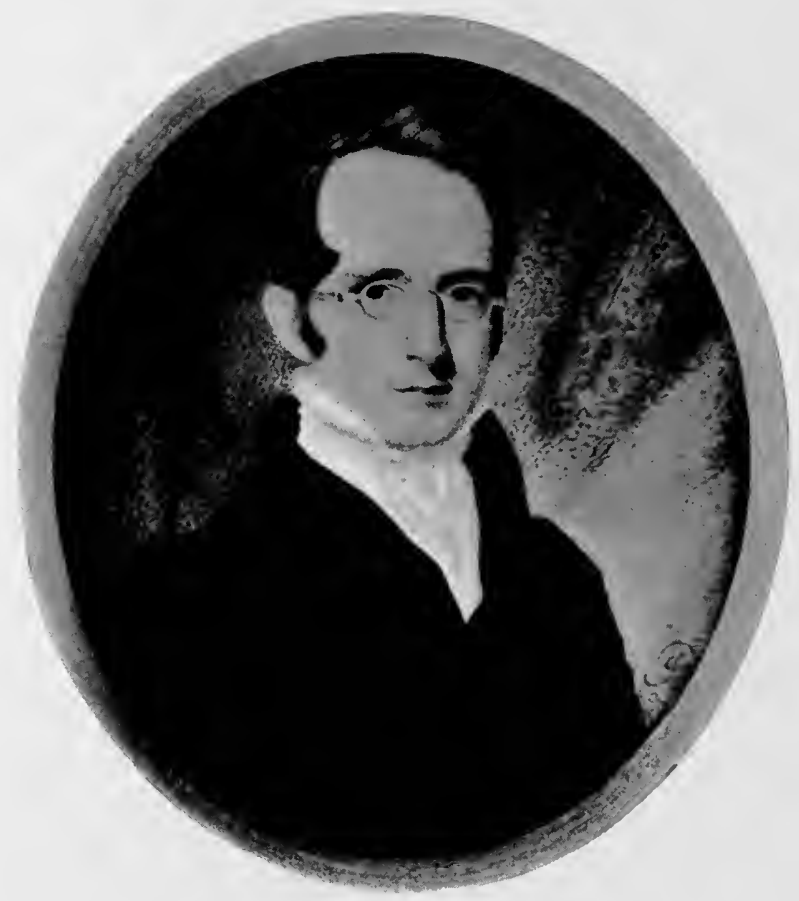

From the Miniature of Dr. Nathan Ryno Smith 

at Boston, but do not know at present at what time I shall be able to gratify that desire.

My family are all well who are now with me. Laura is on a visit at N. H. I believe Solon is getting into considerable repute at Sutton, and as for Ryno, I have not heard a word from him since he removed from Philadelphia to Baltimore. I trust, however, that he is working hard, both for fame and money. James is still with me and will probably take his degree in the spring. John is a fine boy and a good scholar; he will enter college next Commencement.

Our school flourishes tolerably well. We have a class of 9o. They are very fine young men and appear better than any class previous. My health has been unusually good the last year and I have effected as much, perhaps, as I have ever done in one year. Respecting my Surgery, I have written a considerable part of it and expect to get through it the next summer. I should probably have accomplished it before, but have been obliged to write some for my son's journal and several essays to deliver before medical meetings \&c.

I wish you to give my very great regards to $\mathrm{Mr}$. Derby, and remember me affectionately to Mrs. Shattuck and other members of your family.

From your friend,

Nathan Smith.

George C. Shattuck, M.D., Boston."

Six months after writing the last recorded letter to Dr. Shattuck, in July, I828, Dr. Nathan Smith was 
suddenly taken severely ill with a trouble which, although short in duration, left him weak and debilitated. Dr. Knight of Yale, in his biographical memoir of Dr. Smith, says: "From this state his friends perceived with alarm that he did not entirely recover. $\mathrm{He}$ continued to be weak, with occasional attacks of illness, through the remainder of the summer and autumnal months. Though enfeebled in body, his mind retained its usual vigor and activity, and unwilling to yield to what he probably considered a trivial complaint, he continued, with the exception of a few days, his laborious employments. No considerable alteration in the state of his health appeared until about four weeks since [early in January], when he was attacked with a severe influenza. This was accompanied and followed, by a painful and vertiginous affection of the head. . . .

"On the evening of Tuesday, the I $3^{\text {th }}$ inst., he first perceived a slight numbness of the left hand, with a trifling indistinctness in his articulation."

This condition of the father became so alarming that it was considered necessary to notify the two sons who were living at a distance from New Haven, and in answer to the sad letter of one of his sisters, Dr. N. R. Smith wrote the following from Baltimore.

My dear sister :

"Baltimore, January I9, I829.

I am extremely distressed to know that our dear father is so seriously ill. I did not see Dr. Wells till last evening. He informed me of papa's illness, but 
did not think him dangerously sick. I flatter myself, as you are rather timid, you may be more alarmed than there is occasion for. It will be extremely difficult for me to leave Baltimore at this time, but nothing shall keep me from the sick bed of the kindest, the best of fathers; I shall wait one day,-perhaps two,arrange business which I cannot honorably neglect, hoping also to receive further intelligence from you; I shall then proceed as quickly as possible to New Haven.

If my dear father should, in his illness, feel any solicitude about his family, tell him I would have him dismiss it all. Providence has placed me in a situation soon to be able to take his place, in all respects in relation to them. My home, my heart, and my purse will always be theirs, but I trust in Heaven that he may be long spared to us. Tell him that I ask his forgiveness for not having written to him so often as I should have done; it was not from any abatement of affection.

Give my love to our dear mother and to brothers and sisters.

Yours most affectionately,

$$
\text { N. R. Sмiтh. }
$$

N. B. I feel somewhat less anxiety because I think Dr. Ives would have written to me had he thought papa to be in danger. Should papa's situation become more alarming before I see him, I hope that he may be made acquainted with his situation, and pray that he and all his may be resigned to the will of Heaven.

N. R. S." 


\section{CHAPTER EIGHTEENTH}

The beloved doctor was not only surrounded by his large and devoted family during these sad days of suffering and anxiety, but throughout his illness he was tenderly watched by his colleagues and their families by day and by night. Dr. Reuben D. Mussey, his pupil and successor at Dartmouth, was by his bedside with kind ministrations, and Dr. George C. Shattuck, the best beloved pupil and the faithful friend of his lifetime, came from Boston to see him, affording him unspeakable comfort in his last hours by promising to assume responsibility for the education of his youngest son, John Derby, then in his second year at Yale-a promise faithfully performed.

It has been suggested that "these incidents may carry back our thought to the last days of Socrates, surrounded by his disciples, ministering consolation and most deeply interested in his fate." If this be true, the contrast in the two scenes must also be recalled. When Socrates was asked by his pupils for his last legacy the answer came: "If you take good care of yourselves, you will always gratify me and mine most." Could Dr. Smith have uttered a last message, it would have been in the doctrine of his unselfish life and in the words of his Saviour he would have said: "This is my commandment that ye love one another as I have loved you." Before the great Socrates in facing death all was uncer- 
tainty and unrest, for, although believing in the immortality of the soul, he had for his comfort only the vagaries and superstitious teachings of Greek Philosophy; but Nathan Smith, the Christian believer, had for his support the firm foundation laid for his faith in the blessed Word of God, and its precious promises brought to his last hours a sense of perfect peace by the assurance of the forgiveness of sin and of happiness in the world to come.

During the long life of Dr. Smith, he had not regularly connected himself with any particular church, although he attended service always and had the highest reverence for all of the doctrines of Christianity and "had expressed to a friend some months before his illness, his full conviction of the truth of the Christian religion." On its consolations he seemed to rely in these, the closing scenes of his life, "requesting the counsel and prayers of several ministers of the Gospel."

In the week which followed the letter of his son, N. R. Smith, there was no abatement of the dread disease, the "symptoms of paralysis gradually increased, until the morning of the 26 th instant when the powers of life became exhausted, and at 6 o'clock, in the 67 th year of his age, he slept the sleep of death."

So passed from the field of its earthly labors, the beautiful spirit of the man who, following the footsteps of the Master, "went about doing good," and, like the Divine Healer, made the blind to see, the deaf to hear, the lame to walk, and who preached to the ignorant and the afflicted the great Gospel of Healing. 
Nathan Smith left this world a poor man, but who can estimate the value of the legacy which he bequeathed to Humanity, for its price was far above that of gold or of silver or precious stones? His ripe knowledge and keen observation, after a life of study and vast experience, fitted him not only to become the leading physician and surgeon of his day, but, together with a rare talent for communicating the treasures of his learning, enabled him to instruct hundreds, nay, even thousands, of students in the medical schools which he had established. These young men, looking up to Nathan Smith as their professional father, went abroad to cure the sick, and, as the result of his teaching, to raise the standard of medical science to a far greater height of excellence than it had known before.

Nor did his great work for his fellow beings end when he ceased to move among men and teach in bodily presence, for his clear and forcible writings have gone on and on for a hundred years, transmitting to succeeding generations some of the wealth of his discoveries and scientific research. His essays on "Necrosis" and "Typhus (Typhoid) Fever,"- - so far in advance of the enlightenment of the time in which they were written,- -are a marvel to surgeons and physicians of to-day, and are pronounced by them to be classics in medical literature.

Loving and sorrowing friends laid the mortal remains of Nathan Smith away to rest in the Grove Street Cemetery in the lot belonging to the college at New Haven, and erected there to mark the spot a handsome stone with this simple inscription: 


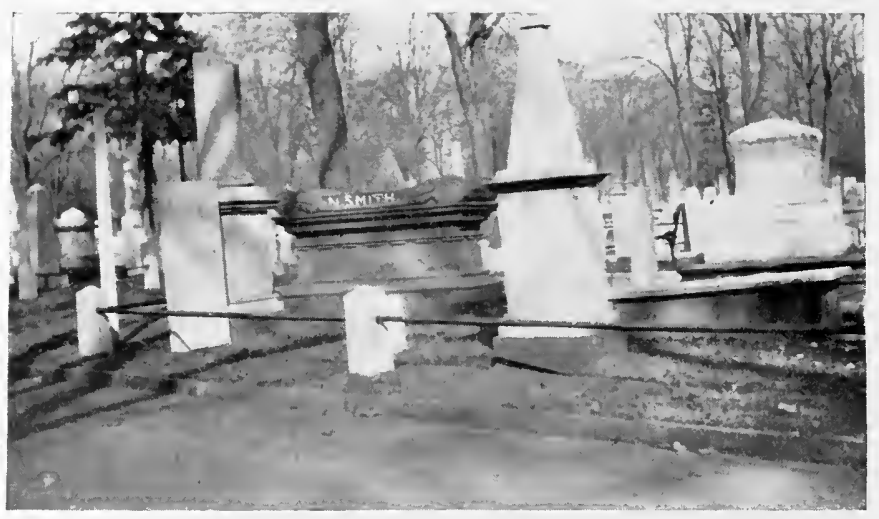

The Grave of Nathan Suith

The dark brown sandstone monument, modeled upon the tomb of the Scipios at Rome, marks the grave of Dr. Nathan Sinitli in the College lot of the Grove Street Cemetery in New Haven. 



\section{N. SMITH}

Professor of Med. \& Surgery

in Yale College

Born at Rehoboth Mass. Sept. 30, 1762.

Died in this City, Jan. 26, 1829.

The best memorials of Dr. Smith are in the schools which he founded and in the steadily growing reverence in which his memory is held. But it is also delightful to know, as has been stated, that Dartmouth has recently erected a beautiful building and called it "The Nathan Smith Laboratory." Very seldom in the world's history have public monuments been erected to the men who have worked to cure pain and save the lives of their fellow beings. "Even the statue, which once graced Trafalgar Square, of the great Jenner, who by his discoveries saved millions of human beings from the scourge of smallpox, was taken down to make room for that of the successful soldier whose laurels were won, not of cives servatos, but on fields red with slaughter."

But if no national recognition has marked the splendid achievements of Nathan Smith, many and eloquent have been the eulogies pronounced upon him by ardent and appreciative admirers of his rare character and work, in the more than eighty years since he ceased his labors on earth.

Very soon after the death of Nathan Smith, Profes- 
sor Knight-his associate and friend at Yale Collegepronounced before a large and interested audience in New Haven an eulogium which bears the mark of his profound and heartfelt admiration for the one whom he designated as having been "no ordinary man," beloved, respected and useful, but even more, for he was "more extensively known than any other medical man in New England. Indeed it is doubted whether any other man in New England, of any profession, possessed so large a number of personal acquaintances and friends. . . . The poor knew him as their benefactor; the sick, as their skilful, attentive physician; the rich were honored by his society; and the wise and the good received him as their friend and companion.

"At the same time his influence over medical literature was equally extensive. This influence was exerted, through his large acquaintance among medical men, by his advice and example, as well as more directly through the medium of the various medical schools, which were favored with his instructions. By means of his influence thus exerted, he effected, over a large extent of country, a great and salutary change in the medical profession. The assertion, that he has done more for the improvement of Physic and Surgery in New England, than any other man, will, by no one, be deemed invidious. ..."

Among the qualities of mind and habits of life which Dr. Knight considered as potent in raising Dr. Smith so far above the ordinary level, he mentions first: "A keen, discriminating inquisitiveness into every thing submitted to his inspection. . . ." 
"Another faculty of his mind was a memory highly retentive. . . . By the aid of this faculty, his mind became a storehouse, well filled with facts suited to his necessities. From it he could, at will, draw forth materials to guide him in his practice; to confirm and to illustrate his opinions.

"Another faculty, which contributed more than either of the foregoing to his eminence, was the power of reducing all the knowledge which he acquired, whether from reading or observation, to some useful, practical purpose. . . . This faculty is familiarly called plain common sense. It was possessed in a high degree by Dr. Smith, in relation to all subjects connected with his profession. The same faculty was illustrously displayed in the lives of Washington, Franklin, Sherman, Dwight and Whitney.

"Another faculty possessed by the deceased, and which aided him much in his successful career, was an undaunted moral courage. . . . With him there was no hesitation, no wavering between duty and expediency; between the welfare of his patient and his own reputation. . . .

"To these intellectual qualities, were added others of a moral nature, which facilitated his progress, and rendered it more successful. I allude to the kindness, assiduity, and delicacy with which he treated his patients. . . .

"As an instructor, the reputation of Dr. Smith was high, from the time he began the business of instruction. . . His mode of communicating instruction, since his connexion with the institution in this place, has 
been simple, natural and unaffected. He sought no aid from an artificial style, but merely poured forth, in the plain language of enlightened conversation, the treasures of his wisdom and experience. He occupied but little time with the theories and opinions of other men, referring to books only for the facts which they contain; nor did he often indulge in theoretic speculations of his own; but gave principally the results of his practice and experience."

Professor Knight's "Biographic Memoir" is full of enthusiastic and heartfelt praise of Nathan Smith, and not only as a physician, surgeon, and teacher, for it bears strong testimony to the beauty and excellence of his character in all of the relations of life. "The interests of literature and sound morality, received his cordial and unvaried support. . . . That benevolence which was so active and so expansive, could not but shed its brightest and warmest rays, upon those who were the nearest and dearest to his heart." After commenting in highest terms upon the "illustrious" life of Dr. Smith, Dr. Knight drew for his audience valuable and instructive lessons from his wonderful example of unselfishness, his enterprise, industry and benevolence. This Memoir was published at the time of its delivery in pamphlet form and was afterwards incorporated by Nathan R. Smith in his "Medical and Surgical Memoirs" of his father. 


\section{CHAPTER NINETEENTH}

Among the many resolutions passed by the various colleges with which Dr. Smith was connected were the following:

Copy of Records of a Meeting of the Faculty of the Medical School of Maine, held on March 6, 1829:

"The Committee appointed at the last meeting to propose such resolutions as it may appear proper for this Faculty to adopt in reference to the death of the late Professor Smith presented the following preamble and resolutions, which were unanimously accepted:

"Whereas the Medical School of Maine, from its commencement in I82I, for five successive years enjoyed the instructions and profited by the fame of the late Professor Smith who was highly distinguished in his profession, and who by years of arduous exertion and by the possession of rich stores of experience had become peculiarly qualified for the duties of a medical instructor, and whereas it has pleased Divine Providence to remove this individual from life, the Medical Faculty of this College in justice to the offices they hold, as well as to their own feelings, would pay the tribute of high respect for his character and grateful recollection of his professional services, therefore

"Resolved: That this Faculty deeply sympathize with the profession in the loss of a public benefactor whose reputation and worth as an able lecturer, a 
skilful surgeon and à successful physician, distinguished by accuracy of opinion, clearness of judgment and benevolence of feeling are universally acknowledged, and that they will ever cherish the memory of one who has contributed so much to the improvement of medical education and the advancement of medical science.

"Resolved: That the President of this Faculty be requested to deliver a Discourse on the occasion of the death of the late Professor Smith before the Medical class and the public.

"Resolved: That the secretary communicate this expression of our views and feelings to the afflicted family of the deceased.

"Adjourned without day.

P. Cleaveland, Sec."

On March 26, I 829, Rev. William Allen, of Bowdoin College, Me., delivered, by appointment of the Faculty of Medicine, a valuable and interesting address commemorating the life and work of Nathan Smith, which was published at the request of the students of the Medical School of Maine.

After an eloquent dissertation on the importance of the work of a physician in general, President Allen gave in outline a sketch of the life of Nathan Smith, bringing the incidents down to the spring of $\mathrm{I} 82 \mathrm{I}$, when by his assistance the Medical School of Maine was opened and Dr. Smith delivered the various lectures, excepting only those on chemistry. Although valuable assistants came to be his associates, he con- 
tinued to lecture in the school for five years, when "from the circumstances of his connection with the institution of New Haven, he found it necessary to decline lecturing in any other establishment." Dr. Allen says that "much of the great success of this Medical School at Bowdoin may doubtless be ascribed to the reputation, experience and skill of Dr. Smith."

The address of President Allen gives valuable testimony to the rare talents and enterprise of Nathan Smith as well as to his unselfishness and high standard of moral excellence. It tells of his "remarkable gentleness and kindness which gained the confidence and affection of his patients; of his fidelity and assiduous, unremitted attention to the sick, and of his cheerful, selfdenying, unmercenary toils and exposure to cold, hunger, and various hardships and dangers in visiting the abodes of the poor. In some great men there seems to exist a strong power of repulsion, but the manners of Dr. Smith were attracting and delightful. He had a keen relish for the pleasures of social intercourse. He was steady and permanent in his friendships, and by his numerous pupils he was beloved."

President Allen gives a most touching and graphic account of the last illness of Dr. Smith, telling of his firm faith in the Christian religion and of the peace which soothed his last hours. From this part of the address the writer has already quoted.

On July 3I, I879, fifty years after the death of Dr. Smith, Dr. Oliver P. Hubbard, Professor of Chemistry at Dartmouth College, delivered a lecture there introductory to the eighty-third course of medical lectures 
at Dartmouth College, on "The Early History of the New Hampshire Medical Institution, with a Sketch of its Founder, Nathan Smith," from which discourse some extracts have been taken for this book.

No outline sketch of the life and work of Dr. Smith could be more comprehensive or better drawn than this very interesting history, for it is full of information collected from the most reliable sources and the many bright and graphic anecdotes connected with the extensive professional work of Dr. Smith furnish illustrations which make the whole lecture delightfully enjoyable. This valuable history was read by request before the New Hampshire Medical Society, at their semi-annual meeting at Hanover on September I7, I 879, and was afterwards printed in Washington with a steel engraving of Dr. Smith on its front page.

The reputation of Dr. Smith's noble life and splendid achievenents has never suffered eclipse, and as time has gone on many have paid honor to his memory.

In Augusta House, Maine, on June I5, I886, at a banquet given to Dr. H. H. Hills, on the fiftieth anniversary of his practice in medicine, the Hon. J. W. Bradbury said: "Our guest reminds me by certain characteristics . . . of a very eminent physician whose lectures I attended sixty-two years ago. I refer to Dr. Nathan Smith. . . . Strong common sense, a mind clear as crystal penetrating to the bottom of the subject, were the qualities impressed upon me as especially his."

Professor Alfred Mitchell of Bowdoin then followed, saying: "Our school was reared and cared for 
by men of learning and genius, and this latter attribute is not to be limited in its fullest significance when we apply it to the character and professional attainments of Dr. Nathan Smith, of whom I once heard the late Professor Willard Parker, in the course of one of his lectures, exclaim with uplifted arm and lighted countenance: 'Gentlemen, Nathan Smith was a great man, one of the greatest that this country ever saw!!!' and then followed a digression so hearty and enthusiastic and coming from such a source, that we all knew that Nathan Smith was a great man."

Professor Benjamin Silliman sums up in a few words the list of Dr. Smith's additions to the science of healing. He says:

"Dr. Smith was an original investigator. . . . Among the numerous important contributions made by him to the resources of practice in surgery involving scientific principles and original operations may be mentioned that, next to Dr. McDowell of Kentucky, he was the first in this country to perform the operation of extirpating ovarian tumor (though the operation had been once or twice performed in Germany unbeknown to either of these American surgeons). He was the first to perform in this country the operation of staphyloraphy. $\mathrm{He}$ devised and introduced a method of amputating the thigh which bears his name. In the pathology of necrosis he developed important scientific principles on which is founded a new and successful practice. His mode of reducing dislocation of the hip joint was new, ingenious and philosophical, as also is the apparatus he invented for the treatment 
of fractures which has been generally adopted by the best surgeons in all parts of the country."

Professor Samuel D. Gross of the Jefferson Medical School of Philadelphia wrote of Dr. Smith as follows:

"One of the most extraordinary medical men whom this country ever produced, whether we regard his great ability as a general practitioner, his skill and daring as a surgeon, or his versatility as a teacher of the different branches of medicine, was Nathan Smith of New Haven. . . .

"This wonderful man, a true pioneer in the cause of medical education, lectured early in life upon all the branches of medicine then taught at Dartmouth College and enjoyed for a long time almost an unrivaled reputation as a surgeon, teacher and general practitioner in the New England States. In his tract on fevers, he shows himself to have been a sagacious observer, thoroughly acquainted with the nature and treatment of the disease which he has so well described." ${ }^{21}$

It would be impossible to enumerate in this history all the eulogies pronounced on Dr. Smith since his death in 1829 ; but that of Dr. William $\mathrm{H}$. Welch cannot be omitted, for it is the highest praise from the highest authority in this present century of advanced science and enlightenment. The address of Dr. Welch on "The Relation of Yale to Medicine" was delivered on October 2 I, I90r, at the two hundredth anniversary

21 Quoted from the American Journal of Medical Science of April, 1876, p. 434. 
of the founding of Yale College and reprinted from the Yale Medical Journal for November, I90I.

\section{(From the address of Dr. William H. Welch.)}

Dr. Welch states that: "Dr. Nathan Smith, when he came to New Haven from Dartmouth, was already a star of the first magnitude in the medical firmament. Starting a poor boy in a small village in Vermont, he managed by his own efforts to obtain a good general education, and then at the Harvard Medical School and in Great Britain a medical education of a character then almost unknown in New England. He was the originator of the Dartmouth Medical School in I797, the most distinguished member of the first Medical Faculty of Yale, and in 1820 the organizer of the Medical Department of Bowdoin College. He did much of his most important work in New Haven, where he remained until his death in $\mathrm{I} 829$.

"Nathan Smith shed undying glory upon the Yale Medical School. Famous in his day and generation, he is still more famous to-day, for he was far ahead of his times, and his reputation, unlike that of so many medical worthies of the past, has steadily increased, as the medical profession has slowly caught up with him. We now see that he did more for the general advancement of medical and surgical practice than any of his predecessors or contemporaries in this country. He was a man of high intellectual and moral qualities, of great originality and untiring energy, an accurate and keen observer, unfettered by traditions and the- 
ories, fearless, and above all, blessed with an uncommon fund of plain common sense.

"Nathan Smith's essay on Typhus Fever, published in 1824 , is like a fresh breeze from the sea amid the dreary and stifling writings of most of his contemporaries. The disease which he here describes is typhoid fever, and never before had the symptoms been so clearly and accurately pictured. He recognized that this fever is due to a specific cause and is self-limited. It took courage in those days for a physician to write, 'During the whole course of my practice I have never been satisfied that I have cut short a single case of typhus, which I knew to be such,' and again, 'It does not follow, of course, that this disease in all cases requires remedies, or that a patient should necessarily take medicines because he has the disease.' To him the lancet was not the 'magnum donum Dei' that it was to Benjamin Rush, and he did more to do away with its indiscriminate use than any single man. The treatment which he advocated-cold water, milk and avoidance of all violent remedies-is practically the same as that now employed, but it was many a day before physicians came to accept Dr. Smith's revolutionary views.

"To the surgeon, Nathan Smith's paper on the Pathology and Treatment of Necrosis has in course of time become as much of a classic as the essay on Typhus Fever is to the physician. Here we find the same admirable description of symptoms, and the introduction of methods of treatment which anticipated modern surgery. This is not the occasion, even did 
time permit, to describe Dr. Smith's achievements in surgery. It must suffice to say that he was the first to perform a number of important surgical operations, and that in this branch, not less than in medicine, he was an innovator and reformer.

"Although none of Dr. Smith's colleagues can be placed in the same rank with him as contributors to medical knowledge, they were men of excellent attainments and became distinguished teachers." 


\section{CHAPTER TWENTIETH}

It may be interesting to the readers of this biography to learn something further about some of those who have held a prominent place in its pages.

The good wife of Dr. Nathan Smith outlived her husband by twenty years. The early part of that time Mrs. Smith spent in her home in New Haven with her younger children before going to live for two years in the home of her son, Dr. Nathan Ryno Smith, in Baltimore. It was there that her daughter, Sarah, was married to Mr. James Osgood of Springfield, Mass. By their invitation she accompanied them to their home, where, after a few years, she was released from her earthly labors, on September 7,1848 , and her children laid her away to rest in the beautiful cemetery of Springfield in the lot of her son, Dr. James Morven Smith.

Dr. George C. Shattuck, pupil, lifelong friend and benefactor of Dr. Nathan Smith and his children, died on March I8, I854.

The many tributes of admiration and respect to Nathan Smith, extending over so long a period after he had ceased his labors among men, are certainly most unusual, and, coming from such distinguished and disinterested sources, bear strong testimony to the nobility of the man and to the magnitude of his achievements. But what honor to the memory of such a man as Nathan Smith could be greater than that his descend- 


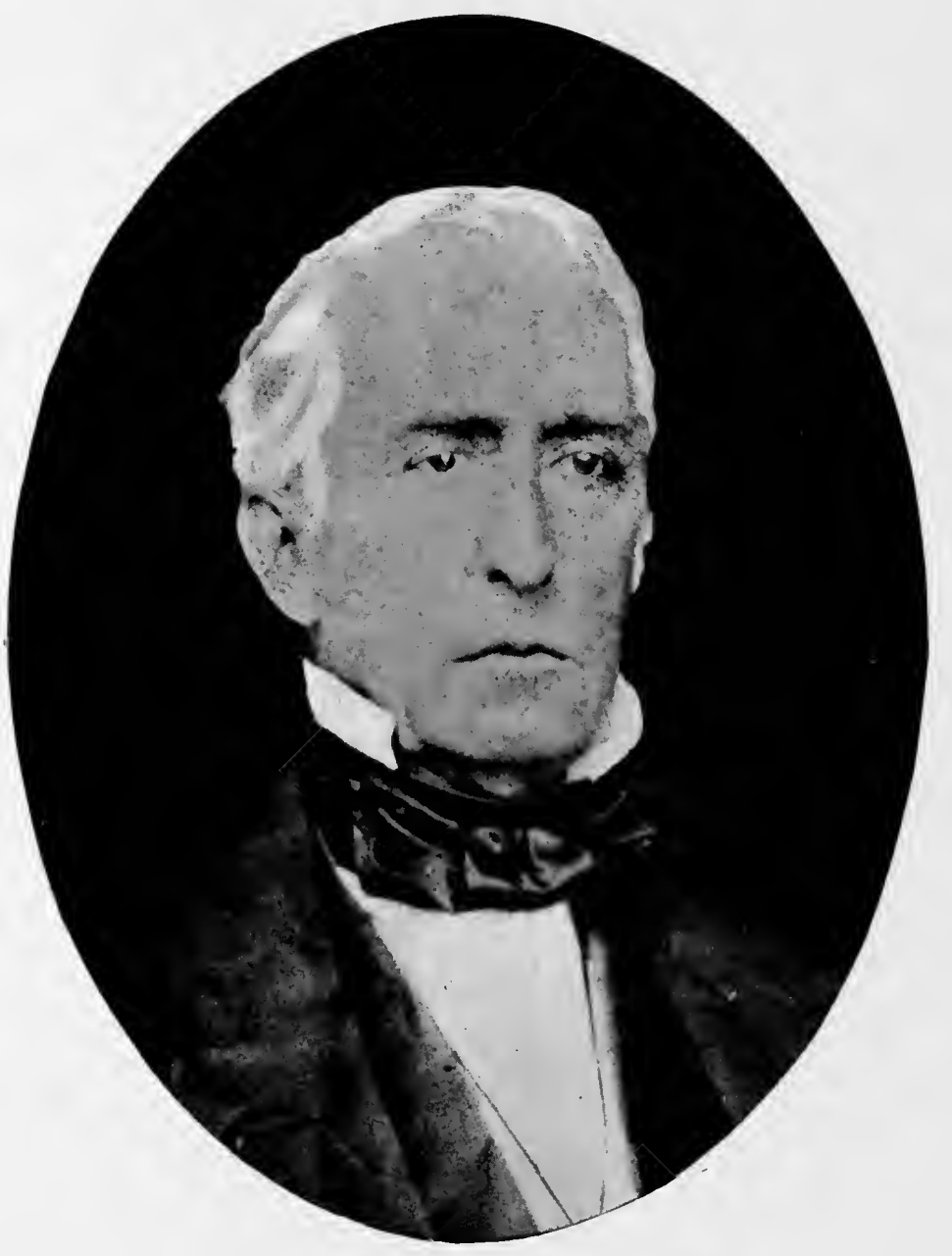

Dr. Davin Solon Chase Hall Suith

Eldest Son of Dr. Nathan Smith 

ants should take up and continue his work, that through them suffering humanity might still receive the benefits which he so unselfishly strove to scatter?

It is probable that there is hardly a family in this country in which so many of its members have adopted the profession of their progenitor. Since the death of Nathan Smith, four sons, nine grandsons, six greatgrandsons and one great-great-grandson have already more or less successfully practiced the art of healing. As a pioneer in the profession he had indeed to fight his way past almost insurmountable obstacles through the dense ignorance which surrounded him, and blaze the way for those who were to follow; but even after the pathway was made clear, success for them was not assured; in addition to inherited genius and talent for the profession, courage and industry were needed to enable the Smith surgeons and doctors to push their way through increasing competition and newly arising difficulties towards still higher and ever widening discoveries in the science of medicine.

All four of the sons of Dr. Nathan Smith became physicians and surgeons of note.

The eldest son of Dr. Nathan Smith, Dr. David Solon Chase Hall Smith, born June 27, I795, died April 6, I859. Yale M.D. I 8 I6.

For nearly thirty years Dr. Solon Smith, as he was called, was the leading physician and surgeon of Sutton, Mass. His thorough training and the prestige of his father's fame brought him also a large consultation practice at a distance from his home. "He was distinguished as a naturalist, being intimately acquainted 
with animal nature, birds and reptiles, and, having made a special study of botany, could classify and give the medical properties of nearly all the plants of this country." His historian, from whom we quote, said of him, "Like his father he was a great man but never became rich." His home life was clouded by sorrow, for he outlived all five of his children, and his experiences, although at times full of romance, were also full of pathos. In I 848 he removed to Providence, where, eleven years later, he died, aged sixty-four years.

The second son of Dr. Nathan Smith, Dr. Nathan Ryno Smith, born May 21, I797, died July 3, I 877 . Yale A.B., I8I 7 ; M.D., I 820 ; Princeton LL.D., I 862.

The beginning of the brilliant career of Dr. N. R. Smith has already been portrayed in this history and his steady rise to great eminence in the profession is well known. As has been shown, he assisted his father in establishing the Medical School of the University of Vermont, in 1822 , and after filling there the Professorship of Surgery and Anatomy for several years, he joined Dr. McClellan in I 825 in founding the Jefferson Medical School of Philadelphia where for two years he held the Professorship of Anatomy, before accepting the call of the University of Maryland to become its Professor of Anatomy. Here by an exchange with Professor John B. Davidge he was almost immediately transferred to the Professorship of Surgery.

Except for an interval of three years, from 1837 to I 840, when he served as Professor of Surgery in the Transylvania School of Kentucky, Dr. Nathan R. 


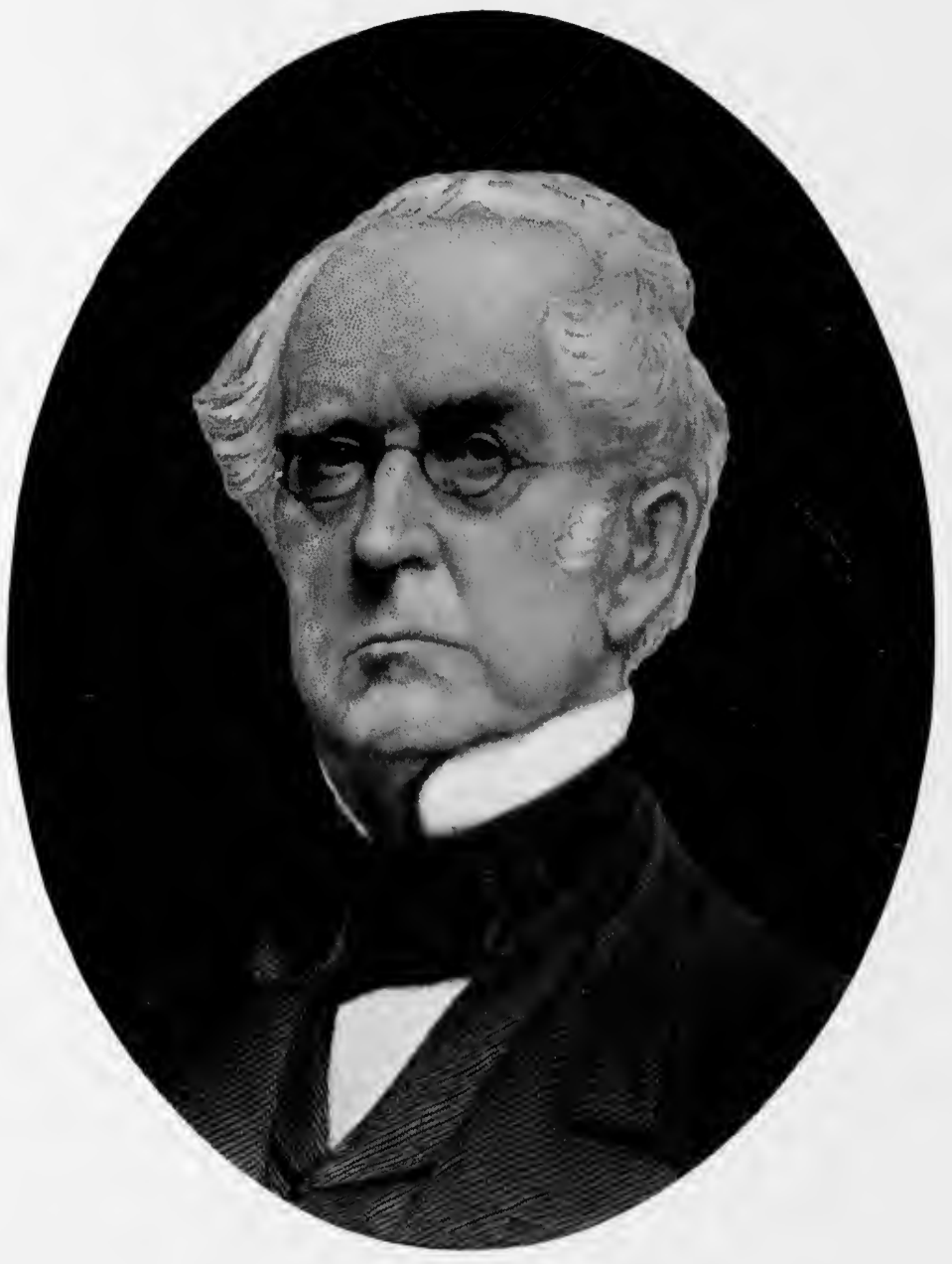

Dr. Nathan Ryno Smith

Second Son of Dr. Nathan Smith 

Smith devoted his splendid energy to the interests of his work in Baltimore.

He was a great surgeon, a learned and interesting teacher, as well as an able writer and an ingenious inventor of surgical instruments. By inheritance from his father, Dr. Smith possessed a remarkable acuteness of perception and promptness of action, and his many fine qualities, together with a commanding presence, obtained for him from his students the title of "The Emperor." So beloved was this great physician that the name of Professor Nathan R. Smith was a household word throughout the State of Maryland.

Among his inventions, Dr. Smith himself regarded his anterior splint as his chief contribution to surgical appliances, but hardly second in importance to the surgeon was his lithotome, to which his son, Dr. Alan P. Smith, attributed much of his own phenomenal success in lithotomy. Dr. Nathan R. Smith found his anterior splint already in use in the noted hospitals of Europe when he visited them in 1867 , and he also found that his professional reputation had preceded him to the Old World, for he was welcomed and entertained by the most distinguished physicians and surgeons of London and Paris, among the number Sir James Paget and Sir Spencer Wells. The later afterward visited Dr. Smith in Baltimore.

On account of his vigorous constitution, Dr. Nathan $R$. Smith retained his activity to an advanced period of life, but gradually a disease incident to old age gained upon him until "finally on the $3 \mathrm{~d}$ of July, I877, a few 
weeks after he had completed his eightieth year, the conflict ceased and he slept in death."

The third son of Dr. Nathan Smith, Dr. James Morven Smith, born September 23, I805, died April 26, I 853. Yale M.D., I 828.

Dr. J. M. Smith became a student in the academic department of Yale at an early age; he began the practice of medicine at Westfield, but removed to Springfield, Mass., where for nearly twenty years he was a highly successful practitioner of medicine among the prominent families of the place. He was devoted to his patients and greatly beloved by them. When still in his prime (aged somewhat less than forty-eight years) he was cut off by a tragic death in a railroad accident at Norwalk, Conn.

The fourth son of Dr. Nathan Smith, Dr. John Derby Smith, born April 9, I 8 I 2, died April 26, I884. Yale A.B., I 832 ; University of Maryland M.D., I 846.

Before studying medicine, Dr. J. D. Smith studied and was ordained a Congregational minister in the Andover Theological Seminary. His charge was at Charlemont, Mass., where he preached for ten years, but then had to give up his pastorate on account of throat trouble and took up the study of medicine under the direction of his brother, Dr. N. R. Smith, in Baltimore.

During the Civil War, he was assistant surgeon in the Fairfax Seminary hospital and he afterwards served for two years as surgeon in the United States Navy. Dr. John Derby Smith was brilliantly talented and a fine classical scholar, and, had he given his undi- 


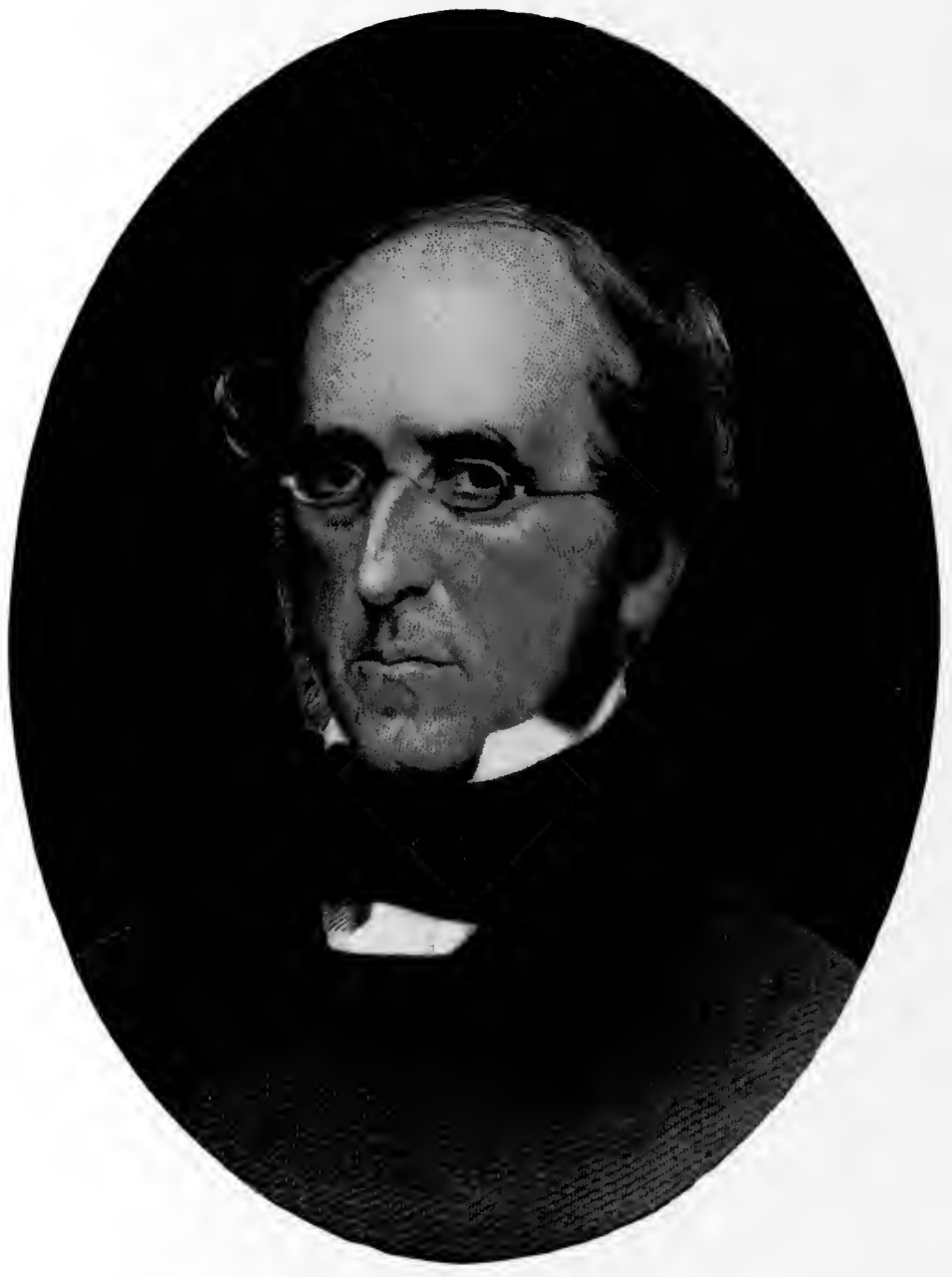

Dr. James Morven SMith

Third Son of Dr. Nathan Smith 

vided attention to the practice of medicine, his reputation for skill might have rivalled that of his brothers, but as it was, he was both an eloquent preacher and a good physician.

Dr. Nathan Smith Lincoln, grandson of Dr. Nathan Smith and son of Rev. Increase Sumner and Gratia Eliza (Smith) Lincoln, born April 3, I822, died October I4, I898. Dartmouth A.M., I850; University of Maryland M.D., I 852 ; Dartmouth LL.D., I 892.

Dr. Lincoln occupied four chairs in Columbian University of Washington, D. C.,-Chemistry, 'Theory and Practice of Medicine, Anatomy and Physiology, and Surgery, and was Professor Emeritus at the time of his death. President Lincoln signed his commission as surgeon of the District of Columbia Volunteers in May, 1861, and he had five hospitals under his charge, as surgeon-in-chief, which position he held during the Civil War and for some months after its close.

Dr. Lincoln was not only a great surgeon; he was also a great physician. This was achieved through his unusual power of diagnosis, a direct inheritance from his grandfather, Dr. Nathan Smith.

Dr. Lincoln was called in consultation to attend President Garfield, and was the only surgeon who made a correct diagnosis of the wound, as was proved by the autopsy.

Dr. Lincoln held many important professional positions, and his general practice among the influential citizens of Washington was very extensive. $\mathrm{He}$ was greatly beloved by those who knew him well and by his 
unusually attractive personality made many friends. Although he lived to the ripe age of seventy-six years he retained his professional activity almost to the last of his long life.

Dr. David Paige Smith, son of Dr. James Morven Smith, born October I, I 830, died December 26, I880. Jefferson Medical School, Philadelphia M.D., I 853.

After being graduated in medicine from Jefferson Medical School, Dr. David Smith studied under distinguished surgeons in Edinburgh, London and Paris.

In $186 \mathrm{I}$ on his return to America he enlisted in the United States Army as surgeon of the Eighteenth Massachusetts Infantry regiment, was soon promoted to be brigade surgeon, and at the end of the Civil War was retired with the brevet rank of lieutenant-colonel. $\mathrm{He}$ then resumed the practice of medicine and surgery in Springfield, Mass., but was called in 1873 to the chair of Theory and Practice of Medicine in the Yale Medical School. After serving for nearly four years he relinquished this professorship to accept the chair of Surgery in the same university. "The personality of Dr. David P. Smith was unique and strikingly individual,-quick, abrupt and positive,-characteristics in part hereditary," and like his grandfather he was a very skilful and well-known surgeon. The loss of his only child, a lad of ten years, deeply saddened his life, but seemed to increase his strong sympathy for others in trouble. Dr. David Smith's life was full of good deeds and the large estate of his wife and himself was bequeathed by them in part to Yale University and the 


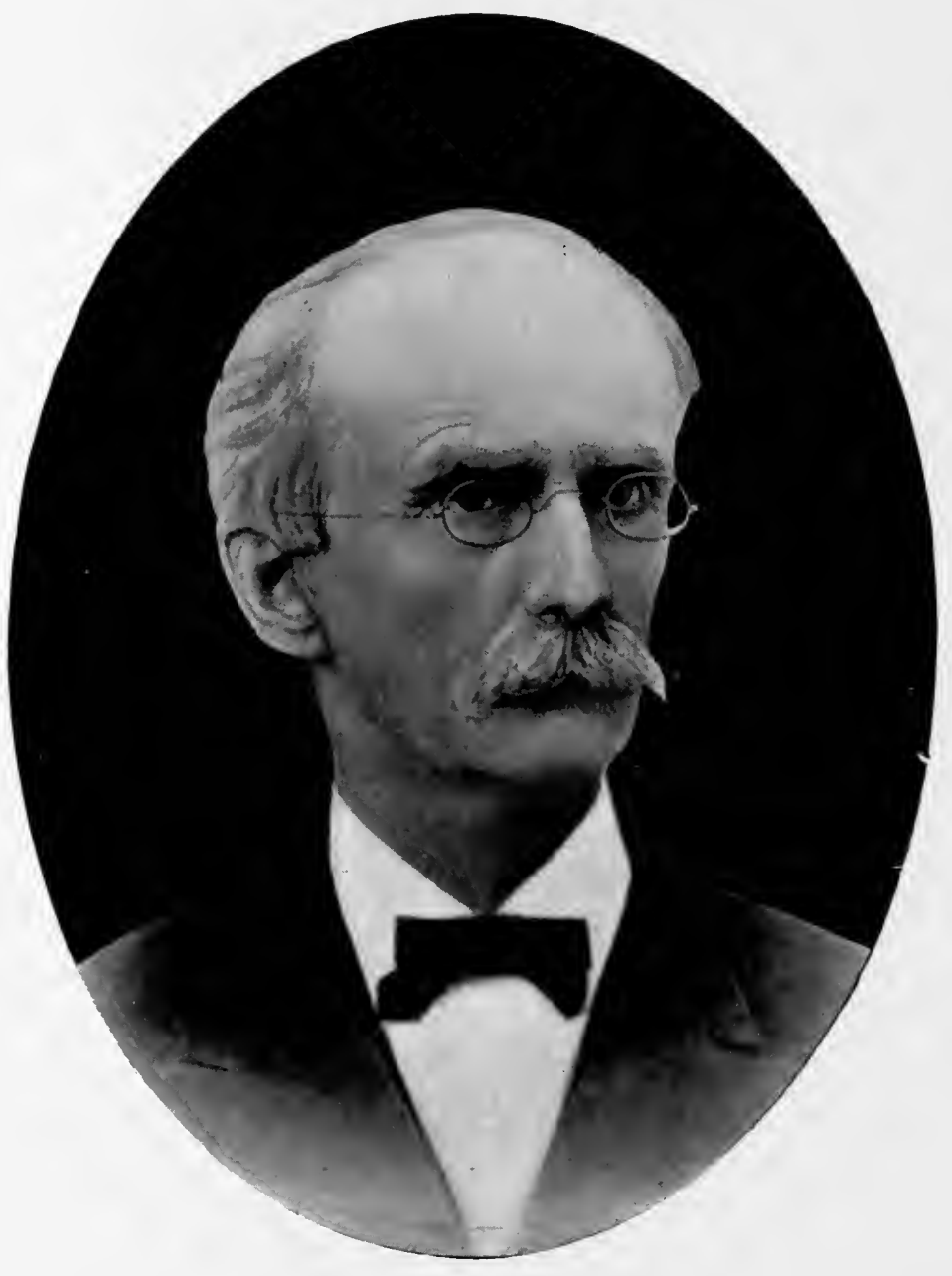

Dr. John Derby Simti

Fourth Son of Dr. Nathan Smith 

rest to the establishment of a hospital for children in Springfield as a memorial to their beloved son..

Dr. Alan Penniman Smith, third son of Dr. Nathan Ryno Smith, born February 3, I840, died July I8, I 898. University of Maryland M.D., I 86I.

It is seldom in the history of any profession that a steady rise to distinction is begun at such an early age as in the case of Dr. Alan P. Smith.

At the time of his graduation in medicine, his father had reached the zenith of his fame and in his large practice in medicine and surgery needed the assistance of this, his only living son. Fine training, great industry and ambition, together with his rare inheritance of talent, soon caused Dr. Alan P. Smith to be recognized a leader in the profession.

In 1868 , having been instrumental in obtaining from Mr. Hopkins the gift to the city of Baltimore of the Johns Hopkins Hospital, he was selected by the donor to be one of the incorporators of the Johns Hopkins University and a member of the board of trustees of the hospital and later was elected to fill a vacancy on the board of the University.

In I 873, Dr. Alan P. Smith was called to the Professorship of Operative Surgery by the University of Maryland. After successfully filling the chair for one season, he resigned his professorship, preferring to devote undivided attention to his very extensive practice. Although he made no specialty of surgery, his marked success in that department commanded the attention of the profession, and at the request of the Medical and Chirugical Society of Maryland, in 1878 , 
Dr. Alan P. Smith read a report of his first fifty-two cases of lithotomy, without a single loss by death. This phenomenal record so increased his reputation as a surgeon that cases came to him from all over the country, and continued success crowned his professional labors until, from overwork, his health became impaired, and, after a lingering illness, Dr. Alan Penniman Smith died at the age of fifty-eight years. In summing up this brief account of his life, we quote from the minutes of the board of Johns Hopkins University:

"The distinction of Dr. Alan P. Smith extended far beyond the city of his residence and largely rested upon his success in surgery, especially Lithotomy, although he was widely known as a general practitioner. For his gentleness, sympathy, courage, knowledge, and skill, he was respected and beloved by all classes in the Community."

These sketches of the professional work of the four sons and of three of the grandsons of Dr. Nathan Smith exemplify in a remarkable manner the advantages of inherited talent. His good work has been carried forward by his descendants from generation to generation not only as far as the third, but the fourth and fifth generations now have their worthy representatives doing notable work in the profession of their distinguished ancestor.

When we consider the far-reaching influence of the work of Dr. Nathan Smith upon the community at large, not only as having been a most skilful physician 
and surgeon, but in the effect of his rare example of rectitude and self-sacrifice, in his untiring energy in seeking knowledge in spite of almost insurmountable difficulties, and lastly in his careful teaching and training of thousands of young men who went forward from his lecture halls to practice and train others in the arts of healing, we must realize with one of the many who have sounded his praises that "Dr. Nathan Smith was one of the most extraordinary medical men that this country has ever produced" and we feel that the Medical School of Yale University may be proud to honor the memory of one who was so intimately connected with its success as well as so instrumental in bringing the school into existence a hundred years ago. 



\section{THE APPENDIX}

Dr. Hubbard says: "The publications of Dr. Smith are not numerous. He began to write as soon as he commenced practice. The earliest papers yet discovered are a 'Dissertation on the causes and effects of spasms in Fevers,' in the Massachusetts Magazine, vol. 3, I79I, January, p. 33, February, p. 8I, and another, 'Observations on the positions of patients in the operation for Lithotomy, with a case of a man seventy-two years old,' published in a letter to Dr. Lettsom, in the Memoirs of the Medical Society of London, vol. 6, p. 227, i 805 .

"He edited with copious notes and additions, 'A treatise on Febrile Diseases, by A. P. Wilson Philips, M.D., $2 \mathrm{~d}$ American from 3 rd London edition, Hartford, I 8 I 6,2 vols.' He contributed valuable papers to the Philadelphia Monthly Journal, some of which were reprinted in the French Medical Journals."

One of the most important and best known of his writings is a "Practical Essay on Typhus (Typhoid) Fever," 8vo., I 824, New York.

"The late Dr. A. B. Crosby, in referring to it in an address delivered a few years since before the Medical Society of New Hampshire, took occasion to say that it was the first comprehensive description of typhus fever ever written and covered in a wonderfully exhaustive way, not only the clinical history, but the pathology of this remarkable disease. 'Many years 
later,' he continues, 'in the great hospitals of Paris, Louis made, and afterward published, his own observations regarding the same disease, and the whole world rang with plaudits of admiration at his genius and learning; but in this little tract of Nathan Smith the gist and germ of all the magnificent discoveries of Louis are anticipated." -Address of Dr. Gilman Kimball.

This appeared again in the "Medical and Surgical Memoirs," published by his son, N. R. Smith. His hitherto unpublished introductory lecture at Yale on the "Progress of Medical Science," which was probably the first lecture delivered in the Medical Department of Yale University, is of sufficient interest to be included here. 
INTRODUCTORY LECTURE ON THE PROGRESS OF MEDICAL SCIENCE

The science of medicine or the art of preventing and curing diseases has, by the most intelligent part of mankind, ever been considered a subject of great importance to society, and of course has in all ages and in all civilized countries engaged the attention and employed the talents of some men of the first grade of intellect, so that by tracing its progress we bring to view the operation of the human mind on a subject as difficult of investigation as anything which has been the subject of human inquiry.

It has been said, that there never was a time since the human race existed in which there was no physician. Be this as it may, we have no distinct account of physicians at a very early period of society. It has been stated by some historians that before Hippocrates lived the profession of physician was usurped by the priests; and that they had some share of the practice, or pretended to the knowledge of remedies, is more than probable; even since the Christian era this has been the case in certain countries; for instance, the Jesuits introduced the use of the Cinchona or Peruvian Bark as a remedy for intermittents and kept it as a secret for some time; from them it had the name of Jesuits' Bark.

But notwithstanding the interference of the priests in the practice of medicine, I should think, from the mention made of physicians in the Old Testament, and 
especially in the Apocryphal writings, that there were at the time in which they were written,- - which was long before the Christian era, - a class of men called physicians whose business it was to cure diseases and attend the sick. But we have no account of their theory or practice, as they have left no writings on the subject that have come down to us, so far as I know.

The first certain account we have of medicine as taught and practiced by a distinct profession is from the writing of Hippocrates, a Grecian, born about 400 years before the Christian era, who left several books on medical subjects which have been transmitted to us through many ages.

That there was such a person as Hippocrates, who lived about the time above stated, and who was greatly celebrated for his skill in curing diseases, I believe is not doubted by any, but that we have received all his writings, or that all that have passed under his name were actually written by him, has been doubted by some, and if we consider that when Hippocrates lived, books were written and not printed, and, of course, that the copies must be few and the knowledge of them confined to a small number; and, further, if we consider that they were preserved in this way for many ages, we shall have some reason to doubt whether those books which have been attributed to Hippocrates were all genuine. But this does not materially affect our present purpose, for though they may not have been wholly written by him, yet they undoubtedly show the opinions of physicians on medical subjects at or about the time he lived. 
Of those writings which are attributed to Hippocrates it is observable that the phenomena of diseases, especially of acute diseases, are described with great accuracy and those symptoms or appearances which enable the physician to foresee the event of the disease, whether favorable or unfavorable, have never been more clearly pointed out. So far the subject of disease lay as open to him as to us, because it was within the reach of his own observation; he could observe and remember as well as those who came after him, and perhaps few men have lived since who possessed a more discriminating mind or a sounder judgment. But it is the explanation of the phenomena of disease and the modus operandi of remedies which mark the difference between the theory or reasoning of Hippocrates and the modern theory.

This difference, in which perhaps the moderns have greatly the advantage, does not depend on the superior understanding of modern folks, but on a cause of a different nature.

It has been justly said that men can reason but from what they know, and Hippocrates was ignorant of many important facts which have been discovered since his day which were requisite to a rational theory of medicine. Hippocrates was almost totally ignorant of anatomy and of physiology, a knowledge of which may be considered as the foundation of all medical science. This Hippocrates has somewhere in his writings acknowledged; he says-if I mistake not-that he never saw but one skeleton and that but for a short time. Hippocrates, however, had a better excuse for 
his ignorance than some who have lived since, who neglect the study of anatomy through want of industry and a dislike of application of every kind. It is not to be supposed that a man so industrious, so fond of a knowledge of the works of the Creator and such a close observer of them, would not gladly have embraced the study of anatomy if the superstitious people would have permitted it.

This pernicious idolatry of mankind with respect to dead bodies, - which appears to have been the first idolatry ever introduced into the world,--kept men almost wholly ignorant of the structure of their own bodies nearly 2000 years after medicine was taught as a science, and still continues to harass those who attempt to enlighten themselves and others in a science which has as high claims on the patronage of an enlightened public as any other. Even in times of old there lived some who knew the importance of the profession. The Son of Sirach-who is supposed to have lived some time between the Babylonish captivity of the Jews and the coming of our Saviour-says: "Honor a Physician with the honor due unto him for the uses you may have of him, for the Lord hath created him, for of the Most High cometh healing, and he shall receive honor of the King. The skill of a Physician shall lift up his head and in the sight of great men he shall be in admiration."

After Hippocrates the next physician who became distinguished was Galen, who was also a Grecian; he is reported to have written many books on medicine and to have been a man of great distinction, and such 
was the influence of his writings, as stated by historians, that they were received and considered the standard of medical science by all the learned faculty and medical schools for nearly 2,000 years. In fact, it was essentially the doctrines of Galen which were taught in all the medical schools in Europe till Hermann Boerhaave published his system of physic at Leyden in Holland in the end of the sixteenth century.

During this long period in which Galen's doctrines were considered as canonical, there was but one schism among the physicians and that was effected by Paracelsus, a bold and empirical physician, who, having acquired some knowledge of chemistry and chemical remedies, was appointed professor at Basel. $\mathrm{He}$ and his followers were called chemists or chemical physicians, while those who followed Galen were called Galenists. The contentions between these two sects at one time ran high, and in France, the Galenists, who had antiquity on their side, obtained an edict from the government calculated to put down the chemists by prohibiting the use of chemical remedies. But in this instance it probably happened-as it often does with hot and zealous disputants-that while they both claimed the truth, the truth disclaimed them both. As Galen, like Hippocrates, was ignorant of anatomy and physiology, his theory, though more elaborate than his predecessor's, did not add much to the stock of useful knowledge in a strict point of view.

I have stated above that it was the doctrine of Hippocrates and Galen which greatly prevailed throughout Europe till the time of Boerhaave, but some time pre- 
vious to that, in the latter part of the sixteenth century, the old Grecian doctrine received a shock which, after some struggling, entirely overthrew it. This was the discovery of the true circulation of the blood through the animal body, which was reserved for William Harvey, an English physician.

Previous to Harvey's discovery the circulation of the blood remained a perfect mystery, and the function of the heart and arteries was entirely unknown. This discovery of Harvey's, so all-important in the science of physic and surgery,-instead of being hailed with joy by the medical schools, as we should have expected,met with decided opposition by the professors and many of the learned faculty of that day; and when at length it began to gain ground and to make some noise in the world, some of the older members of the faculty were so irritated by it that they endeavored to get an additional clause added to the oath which physicians were obliged to take when they took their degree.

The discovery of the circulation of the blood did not, however, immediately produce that change in the theory and practice of medicine which we should have expected from its very great importance, especially if we consider what a world of darkness and mystery was dispelled by it. But men, having been taught to reason in a certain way and to view a subject from a certain point of view, do not easily relinquish their opinions. It was Hippocrates and Galen who introduced what has been called the humoral pathology or that theory which supposes that disease is introduced by some change in the fluids which render them unfit for the due per- 
formance of the functions of the body; this change, they supposed, might depend on the quantity or quality of the circulating fluid, or from some matter taken in from without, which circulated in the fluids. After supposing this morbific matter to be in the body, they supposed that there was a principle in the animal system which tended to ward off evil and to preserve the body in health and to restore it when impaired, and that this morbific matter raised this principle of defense, by some called nature, the "vis medicatrix nature," to throw off the offending matter and to relieve the system from it. The outlets through which this morbific matter passed were all the emunctories, that is, it passed by the stomach, by the kidneys, or by the skin; so that disease was by them as a conflict between two forces, the one tending to destroy, and the other to preserve, life; - the more visible symptoms, such as increased heat and action in the blood, which men supposed to be the effort of nature struggling with disease or offending matter, while the offending matter carried on its operations in a more insidious manner and more out of observation.

Imperfect as these doctrines appear to us, they maintained their ground entirely till Dr. Cullen began to give lectures in the University of Edinburgh. Cullen attacked the humoral pathology, which had been taught from Hippocrates down to that time, and the learned Boerhaave had, not long before and even after the discovery of the circulation by Harvey, contributed to establish it on so respectable a foundation as seemed to bid defiance to succeeding generations to demolish it; 
Cullen attempted to show that this doctrine-which considered disease as arising from alteration, deficiency, or superabundance, of fluids-did not account for all the phenomena of disease, and thought it more consonant to sound reason to suppose that many diseases originated from causes which act exclusively on what he calls the living solids.

But Cullen, like many other innovators, did not carry his doctrine to the extent to which it has been pushed since. He did not reject the humoral pathology entirely, but explained the phenomena of several diseases on those principles; for instance, the smallpox, with other eruptive diseases, on a supposition that, by something taken in, the fluids were changed and that a part of them was converted to the nature of the contagion which produced the disease, and this was conveyed off through the skin, or other outlets of the body. $\mathrm{He}$ also gave full credit to what he called the vis medicatrix natura.

The fate of Cullen's writings has been somewhat singular, for, although the time since he wrote is short, yet his particular theory or explanation of disease, excepting so far as it serves to transfer the seat and cause of diseases from the fluids to the solids, is almost entirely obsolete. Yet in this particular Cullen has effected a greater change in medical philosophy than any man who has lived since Hippocrates; for since Cullen's book was published the humoral pathology has gradually declined until, with very few exceptions, no one speaks of disease as depending on the fluids.

After Dr. Cullen published his theory of disease and 
while he was yet living, Dr. John Brown, who had formerly been his pupil, came out with a book which he called "The Science of Life." The book was intended to refute the theory of Cullen in part, but did not go to disprove his doctrine as to the seat of disease being in the solids; on the contrary, he extended this doctrine further than his master.

The peculiar features of Brown's doctrine may be explained in a few words. He supposed that in every animal there was implanted a certain something which he called irritability, or a capacity to be acted upon by certain external agents, which he called stimuli,- that the effect of these stimuli was certain, and further that this excitability was exhausted by the use of stimuli and that it accumulated or increased when the stimuli were withheld or withdrawn, and that health consisted in a due degree of excitement kept up by stimuli, and when it failed for want of a due proportion of stimuli, it was a state of direct debility,-asthenia; but when the stimulus exceeded, or from the previous accumulations of the excitability, the usual portions of stimulus produced actions beyond the healthy standard, it produced a state of the system which he called sthenic, which is the same that others had called inflammatory. Besides these two opposite states of the system he surmised another which he called indirect debility, that state of debility which is produced by an overdose of stimuli, and is supposed to arise from exhaustion of the excitability.

This being the theory of Brown, the practice deduced from it is plain and simple:-if the excitement be too 
great, subtract stimuli till it is reduced to the healthy standard, and if deficient, give stimuli till the actions of the system are brought up to the healthy standard; in cases of indirect debility subtract the stimuli gradually and suffer the exhausted excitability to recover. Upon this plan he formed a scale of disease, in which he placed health in the middle, the highest degree of excitement at the upper end, and death at the lower end. His Materia Medica was made to correspond with his indications, of course; that is, his remedies were such as he supposed either increased or diminished the excitement of the system. Those which increased the excitement he divided into the permanent and diffusible. Food was the principal of the permanent stimuli, and opium, wine and alcohol were the chief of the diffusible. The remedies which dominate excitement, according to his doctrine, were evacuation or the subtraction of heat from the body. He did not consider remedies as having any peculiar or specific actions, but ranked them according to their supposed stimulant powers.

The Brown theory was, in the main, very defective, yet he brought into view certain properties or laws of the animal economy, which, though not entirely overlooked by those who went before him, yet had not been so fully pointed out, and had received no particular name. I allude to his theory of excitability and the effect of stimulants on that principle.

As Cullen, by transferring the cause of diseases from the fluids to the solids, introduced a new theory of 
disease, so Brown introduced a set of new words into medical phraseology which still are continued.

Besides the authors which I have mentioned, there have at different times appeared a multitude of books on medical subjects which have exhibited some peculiarities of doctrine, but none of them have effected any great or permanent change in the theory or practice of medicine. Since the time of Cullen and Brown, medical men have assumed a much bolder and more independent manner of thinking and writing, and these two men have effected the change or contributed materially towards it. They deserve much whether we admit their doctrines as correct or not.

We seem now to have arrived at the proper point for starting. 



\section{INDEX}

Aberdeen, University of, 64 .

Allen, Gen. Ethan, 119.

Allen, Pres. William, of Bowdoin, 99, 109, 110, 111, 112, 148, 149.

American Journal of the Medical Sciences, 135.

Atlee, Dr. Washington L., 130.

Bell, Dr. J., 122, 124.

Black, Prof. Joseph, 18.

Boerhaave, Hermann, 173, 175.

Bowdoin College, 87, 109, 110, 111, 112, 114, 120, 128, 147, 148, 149, 150, 153.

Boylstone, Dr., 45, 46.

Bradbury, Hon. J. W., 150.

Brown, Dr. John, 177, 178, 179.

Brush, Crean, 119.

Chase, Allace, 9.

Chase, Allace (Corbett), 7.

Chase, Dudley, 7.

Chase, Elizabeth, 11.

Chase, Jonathan, 8, 10, 11, 106.

Chase, Mary Dudley, 13.

Chase, Philander, Bishop of Ohio and Illinois, 7, 99.

Chase, Judge Samuel, 8, 13.

Chase, Sarah (Hall), 11.

Chase Smith, Sarah Hall. See Smith, 11.

Chase, Thankful Sherman, 11.

Chauncey, Hon. Charles, 132.

Cleaveland, Dr. Nehemiah, 112.

Cleaveland, Prof. Parker, 111, 133, 148.

Cogswell, Dr. Mason Fitch, 84, 85, 86, 88.

Columbia College, 15, 120.

Columbian University, 161.

Crenshaw, Mr., 136.

Crosby, Prof. A. B., 116, 167.

Crowninshield, Sec. of Navy, 104.

Cullen, Dr. William, 175, 176, 177, 178, 179.

Darby, Henry, 49. 
Dartmouth College, 9, 15, 20, 21, 22, 23, 24, 30, 31, 32, 38, 39, 40, 51, $52,61,62,63,67,75,77,78,80,81,82,87,89,97,100,101,119$, $120,128,140,143,149,150,152,153$.

Davidge, Dr. John B., 135, 158.

Dexter, Dr. Aaron, 10.

Dudley, Samuel, 106.

Dwight, Pres. Timothy, of Yale, 84, 92, 134.

Edinburgh, University of, 16, 153.

Edwards, David S., 102.

Emerson, Brown, 30.

Flexner, Dr. Abraham, 77.

Frost, Dr. Gilman D., 77.

Galen, 26, 27, 172, 173, 174, 175.

Gallup, Dr., 24.

Garfield, Pres. James A., 161.

Goodhue, Dr., 5, 6.

Gross, Prof. Samuel D., 130, 152.

Hall, Rev. David, 13.

Hall, Elizabeth Prescott, 13.

Harvard College, 10, 15, 40, 53, 64, 82, 120, 153.

Harvey, Dr. William, 174, 175.

Hillhouse, James, 92, 96.

Hills, Dr. H. H., 150.

Hippocrates, 26, 27, 93, 169, 170, 171, 172, 173, 174, 175, 176.

Hitchcock, Pres. Edward, of Amherst, 104.

Hoadly, George, 132, 133, 134.

Holmes, Dr. Oliver Wendell, 10, 64, 77.

Hubbard, Prof., 99, 100.

Hubbard, Dr. Oliver P., 10, 23, 24, 32, 40, 76, 82, 93, 129, 149, 167.

Hunter, Dr. John, 115.

Ives, Prof. Eli, 91, 97, 139.

Jarvis, Consul, 67.

Jefferson Medical School, 130, 134, 135, 152, 158.

Jenner, Dr. Edwa rd, 25, 143.

Johns Hopkins University, 163, 164.

Kimball, Dr. Gilman, 114, 115, 168.

Kingsbury, Hon. Sanford, 16.

Knight, Prof. Jonathan, 91, 129, 138, 144, 145, 146.

Lavoisier, 79.

Leavenworth, Dr. M. C., 97. 
Lectures of Nathan Smith, 26, 27, 79, 93, 94, 169-179.

Lettsom, Dr., 63, 167.

Lincoln, Pres. Abraham, 161.

Lincoln, Gov. Levi, 54, 56, 66, 70.

Lincoln, Rev. Increase Sumner, 108, 125, 126, 127, 161.

Lincoln, Dr. Nathan Smith, 161, 162.

Louis, Dr. Pierre Charles Alexandre, 168.

Lowe, Dr. Abraham T., 76, 77.

Maryland, University of, 119, 120, 135, 158, 163.

McClellan, Dr. George, 130, 158.

McDowell, Dr. Ephraim, 114, 115, 129, 151.

Medical and Surgical Memoirs, 83, 146, 168.

Medical Review, 135.

Medical Society of London, 21, 53, 63, 167.

Medical and Chirurgical Society of Maryland, 163.

Mitchell, Prof. Alfred, 150.

Monro, Prof. (Secundus), 18.

Montesque, Monte, 119.

Morse, Samuel Finley Breese, 113.

Munson, Prof. Aeneas, 91.

Mussey, Dr. Reuben Dimond, 30, 140.

New Hampshire State Medical Society, 38, 53, 150, 167.

Nesmith, Hon. George W., 93, 94, 95.

Noyes, Josiah, 30.

Olcott, Mary, 100.

Olcott, Mills, 90, 100, 101.

Osgood, James, 156.

Paget, Sir James, 159.

Paine, Judge, 54.

Paine, Miss, 54, 56.

Paracelsus, 173.

Parker, Prof. Willard, 151.

Parkman, Dr. George, 64.

Patterson, Isaac, 33.

Peck, Rev. Robert, 1.

Penniman, Dr. Jabez, 119.

Pennsylvania, University of, 15, 35, 120, 134.

Perkins, Dr. Cyrus, 34, 51, 54, 60, 61, 64, 83.

Phelps, Daniel, 30.

Philadelphia Monthly Journal of Medicine and Surgery, 135. 
Philips, Dr. A. P. Wilson, 167.

Plato, 26.

Ramsey, Dr. Alexander, 39, 45, 46, 63.

Rush, Dr. Benjamin, 35, 36, 154.

Shattuck, Dr. George Cheyne, 30, 31, 34, 35, 38, 40, 41, 42, 43, 45, 46, $47,48,49,50,51,52,54,56,57,58,59,60,61,63,65,68,69,70$, $71,72,73,74,104,105,106,109,111,121,123,124,130,132,133$, $136,137,140,156$.

Sheffield, Hon. Joseph Earle, 98.

Shurtleff, Prof. Roswell, 62.

Silliman, Prof. Benjamin, 83, 85, 86, 91, 92, 105, 113, 119, 151.

Smith, Dr. Alan Penniman, 35, 159, 163, 164.

Smith, Catherine Camilla, 107.

Smith, Dr. David Paige, 162.

Smith, Dr. David Solon Chase Hall, 13, 17, 18, 19, 21, 61, 62, 89, 96, $101,103,104,105,106,107,108,119,124,131,134,137,157,158$.

Smith, Elizabeth Ide Hills, 2.

Smith, Gratia Eliza, 107, 108, 127, 161.

Smith, Henry, 2.

Smith, Deacon Henry, 2.

Smith, Ensign Henry, 2.

Smith, James Morven, 107, 119, 137, 156, 160.

Smith, John, 2.

Smith, John Derby, 61, 107, 119, 132, 137, 140, 160, 161.

Smith, Judith, 2.

Smith, Juliette Octavia (Penniman), 119.

Smith, Laura Matilda, 107, 137.

Smith, Lucy (Hall), 108.

Smith, Mary Amanda, 107.

Smith, Dr. Nathan, 2, 3, 4, 5, 6, 9, 10,11, 12, 13, 15, 16, 17, 18, 19, 20, $23,24,25,30,31,32,34,35,37,38,39,40,51,53,61,75,76,77$, $81,82,83,89,90,91,93,94,95,97,99,100,101,102,107,109$, $112,113,114,115,116,120,121,125,126,127,128,129,130$, $131,136,137,138,140,141,142,144,145,146,147,148,149,150$, 151, 152, 153, 154, 155, 156, 164, 165.

Smith, Dr. Nathan Ryno, 21, 61, 62, 89, 96, 101, 103, 107, 118, 119, $120,130,132,134,135,136,137,138,139,146,156,158,159,160$, 168.

Smith, Rebecca (Atwood), 2.

Smith, Sally Malvina, 99, 107. 
Smith, Sarah - 107, 108, 156.

Smith, Sarah Hall (Chase), 11, 12, 13, 17, 18, 19, 21, 61, 86, 95, 99, $107,156$.

Socrates, 26.

Spalding, Dyer, 7.

Spalding, Dr. James A., 53.

Spalding, Dr. Lyman, 9, 17, 25, 30, 34, 37, 38, 39, 53, 63.

Spallanzani, 79.

Thacher, Dr. James, 41.

Theobald, Dr. Samuel, 88.

Thales, 26.

Transylvania School of Kentucky, 158.

Trumbull, Benjamin, 102.

Turner, Thomas, 103.

Twitchell, Amos, 30.

Vauquelin, 79.

Vermont, University of, 87, 120, 122, 124, 128, 158.

Warren, Prof. John, 10, 43.

Waterhouse, Dr. Benjamin, 10, 25, 71.

Webber, Prof. Samuel, 10.

Webster, Daniel, 30, 81.

Welch, Dr. William H., 30, 87, 97, 98, 129, 152, 153.

Wells, Dr. John Doane, 105, 111, 122, 123, 124, 131, 138.

Wells, Sir Spencer, 159.

Wheelock, Pres. Eleazar, of Dartmouth, 22.

Wheelock, Pres. John, of Dartmouth, 15, 32, 81, 89, 112.

Whiting, Rev. Mr., 5.

Woolsey, Elizabeth (Dwight), 134.

Woolsey, Mary Anne, 134.

Woolsey, Pres. Theodore Dwight, of Yale, 90, 134.

Woolsey, W. W., 90, 125, 132, 133.

Writings of Nathan Smith on Cancer, Fevers, Necrosis, etc., 43, 44, $83,84,116,121,122,128,137,142,154,167$.

Yale College, 30, 80, 82, 83, 87, 88, 89, 91, 92, 93, 96, 97, 98, 103, 104, $110,114,116,119,120,124,128,129,137,153,162,165$. 






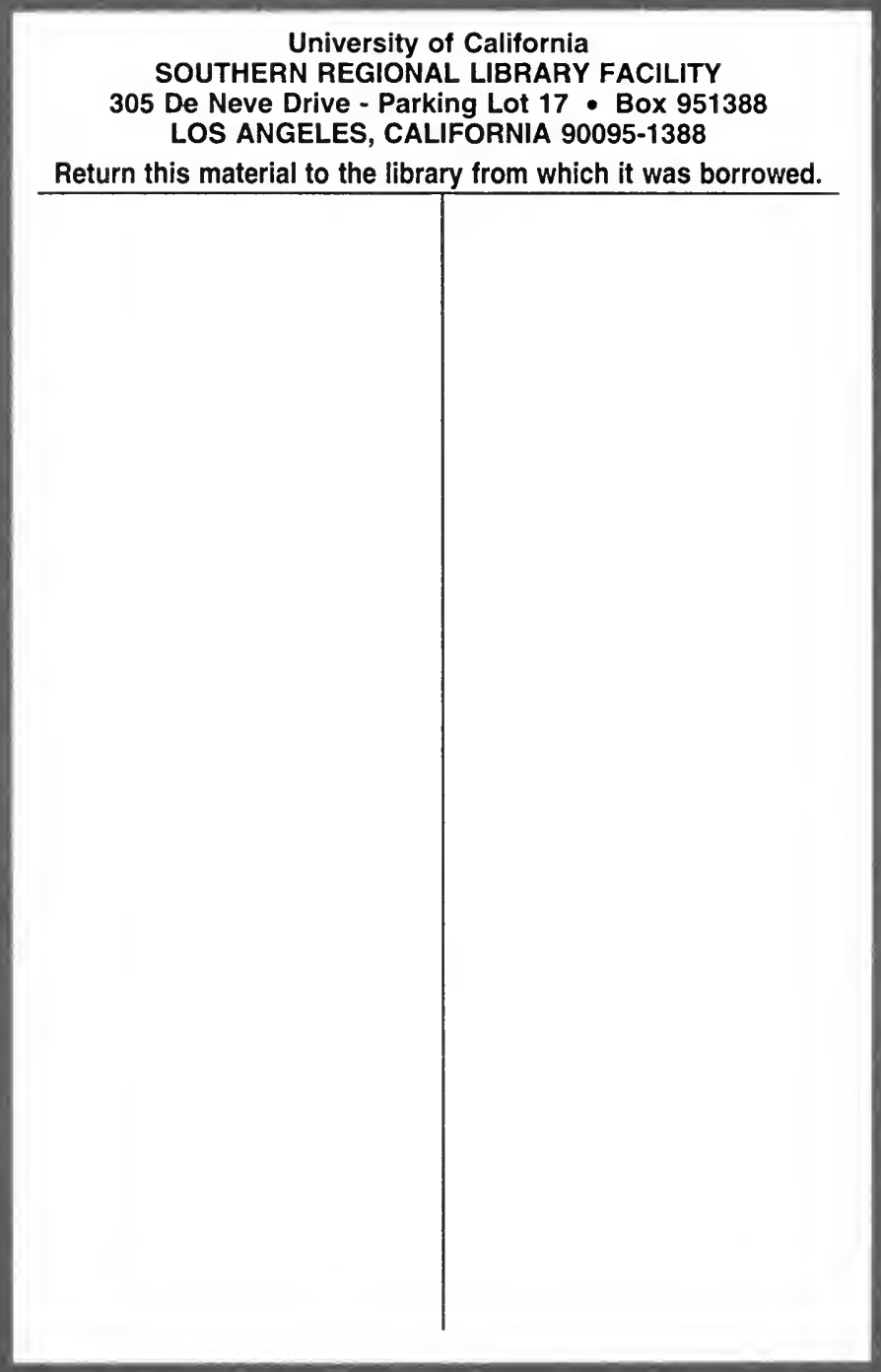




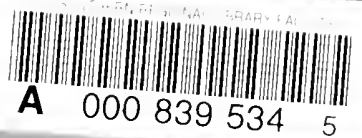


